\title{
Catálogo de ejemplos lulianos
}

\author{
Xavier Bonillo Hoyos \\ Universitat Oberta de Catalunya \\ mailto:xavierbonillo@yahoo.es \\ http://orcid.org/oOOO-O0O2-47I4-9473 \\ Rebut 03/o9/20I4; acceptat I7/O2/20I5 \\ DOI I0.7203/MCLM.2.4045
}

\section{A catalogue of Ramon Llull's exempla}

\begin{abstract}
This article presents for the first time, out of detailed analysis of his major literary works, a catalogue of exempla in Ramon Llull; a list showing the exemplary items used by this author. For every item, a brief characterisation is given, followed by its location within a given work, and its narrative motif, for a total of over 2,ooo exempla.
\end{abstract}

KEYWORDS

Ramon Llull; Raymundus Lullius; exemplum; catalogue; medieval culture; medieval education; medieval preaching; thirteenth century: fourteenth century; wisdom literature.

\section{ə*⿻丷木}

Resumen

Se presenta por primera vez, a partir de un detallado análisis de sus principales obras, el catálogo de exempla de Ramon Llull en forma de lista, en que se muestran los ejemplos usados por este autor. Para cada uno se da un breve título, seguido por su localización en cada obra y por su motivo narrativo, para un total de más de 2,ooo ejemplos.

\section{Palabras clave}

Ramon Llull; Raimundo Lulio; exemplum; ejemplo; catálogo; cultura medieval; educación medieval; predicación medieval; siglo XIII; siglo XIV; literatura sapiencial.

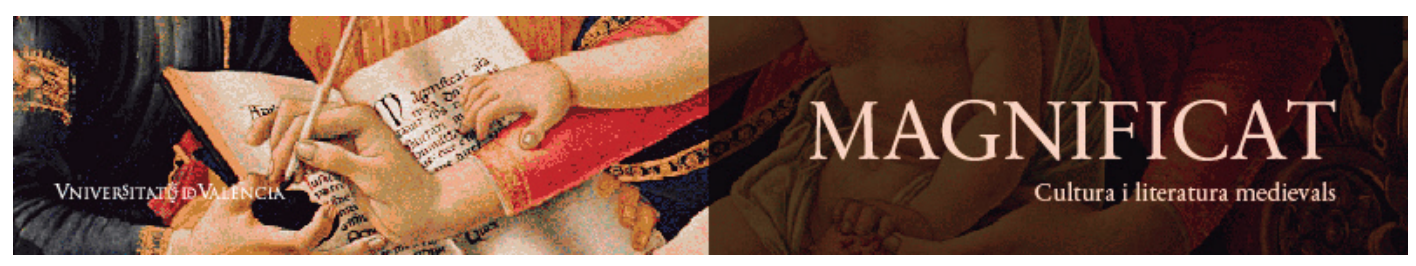

Magnificat Cultura i Literatura Medievals 2, 2015, 55-127. http://ojs.uv.es/index.php/MCLM

ISSN 2386-8295 
Xavier Bonillo Hoyos, 20I5, "Catálogo de ejemplos lulianos", Magnificat Cultura i Literatura Medievals 2, 55-I27. (c) Br

\section{TABLA DE CONTENIDOS}

I Presentación - 57

2. Catálogo de Ejemplos Lulianos - $5^{8}$

2.I Libro de contemplación - $5^{8}$

2.2 Doctrina pueril - 80

2.3 Libro contra Anticristo - 8I

2.4 Libro del gentily los tres sabios - 8I

2.5 Comienzos de medicina - 8I

2.6 Blanquerna - 82

2.7 Libro de los ángeles - 86

2.8 Libro de maravillas - 86

2.9 Libro de santa María - $9^{8}$

2.IO Árbol de ciencia - IOI

2.II Árbol de filosofía de amor - IIO

2.I2 Libro del es de Dios - IIO

2.I3 Libro de conocimiento de Dios - IIO

2.I4 Libro de Dios - IIO

2.15 Retórica nueva - III

2.I6 Del nacimiento de Jesús infante - II2

2.I7 Elfantástico - II2

2.18 Libro de virtudes y de pecados - II2

2.I9 La ciudad del mundo - II7

${ }_{3}$ Ediciones y estudios consultados - II8 


\section{ə*⿻}

\section{Presentación}

El interés por el estudio de los exempla medievales y de sus implicaciones retóricas e intertextuales, que había despertado la curiosidad de los primeros estudiosos de las literaturas románicas del Medioevo, ha renacido de manera sustancial en los últimos años. Varias razones podrían justificar este redivivo interés, tales como la facilidad con que actualmente se pueden consultar los corpus y/o autores/compiladores de ejemplos más destacados o, tal vez, por el gran provecho exegético que se puede extraer de este extenso fondo cultural y narrativo de la edad media.

En estos momentos, se deben destacar tres focos especialmente activos en el entorno de la investigación de los ejemplos medievales. En primer lugar, en el ámbito latino, con la edición, catalogación y estudio de las principales compilaciones de exempla medievales. En segundo lugar, en el ámbito francés, interesado sobre todo en la definición y en la acotación del género, en sus motivaciones e implicaciones sociales y culturales y en su recepción y evolución a lo largo de la edad media. Y, en tercer y último lugar, en el ámbito castellano, centrado especialmente en la edición y estudio de las variadas y valiosas traducciones de textos medievales didácticos de origen oriental y de la relación de éstas con algunos autores castellanos medievales destacados.

Para un general estado de la cuestión, vid. Thompson 1975, Le Goff 1985, Bremond, Le Goff, Schmitt I996, y Polo 20ıo. Para el ámbito castellano, vid. Marsan I974, Palafox I998 y Lacarra I999.

En lo referente al ámbito catalán, cabe señalar que los estudios sobre los ejemplos medievales son relativamente escasos, aunque hay que resaltar la magnífica tarea individual de estudiosos como Pedro Cátedra, Tomás Martínez Romero, David J. Viera o Josep Antoni Ysern. Vid. Neugaard r99I y 1993, Taylor 1995, Ysern 1995, 2004 y 2007; Martinez Romero 2002, Viera 2003-2004, Batalla, Cabré, Ortín 2006, Taylor 2007, y Bonillo 2008.

La idea del Catálogo de Ejemplos Lulianos (CEL) nació siguiendo el modelo del portal Thesaurum Exemplorum Medii Aevi, fundado por el polifacético historiador francés Jacques Le Goff (I924-20I4) y dirigido, actualmente por Marie Anne Polo de Beaulieu. Su base de datos me resultó muy útil para el desarrollo de la tesis doctoral y, de manera especial, para poder aislar algunas posibles fuentes en determinados ejemplos del Libro de maravillas de Ramon Llull (Bonillo 2007). Finalizada mi investigación, creí que resultaría útil (o al menos práctico) elaborar un catálogo en el que recopilar los ejemplos del opus luliano. Así lo hice, y el primer resultado fue el Catálogo de Ejemplos del Libro de maravillas (Bonillo 2008). A partir de aquí, el itinerario a seguir era obvio: se debía acabar el trabajo con el resto de obras destacadas de Llull hasta completar el presente Catálogo de Ejemplos Lulianos (CEL), que aquí se presenta por primera vez.

Para la elaboración del CEL, se han tenido en cuenta las obras más significativas, desde el punto de vista literario, de las 265 escritas por el autor mallorquín. La elección de las obras ha intentado abarcar todos los períodos, estilos y lenguas representativas del opus luliano. Así pues, se ha estudiado como mínimo una obra de cada período evolutivo del pensamiento de Llull y, en todo caso, se han estudiado los principales tratados sobre sermonística en latín y en vulgar; si bien se ha prestado una atención especial a las obras de un cariz más popular y de un carácter más claramente literario, escritas en vulgar. En resumen, las obras que se han tenido en cuenta son las siguientes: Libro de contemplación (Llibre de contemplació en Déu; Liber contemplationis [1273- 
4 (?)]), Doctrina pueril (Doctrina pueril [1274-6]), Libro contra Anticristo (Llibre contra Anticrist [1274-6 (?)]), Libro del gentil y los tres sabios (Llibre del gentil e dels tres savis [1274-6 (?)]), Comienzos de medicina (Liber principiorum medicinae; Començaments de medicina [I27483]), Blanquerna (Romanç d'Evast e Blaquerna [1276-83 - Montpeller]), Libro de los ángeles (Llibre dels àngels [1276-83 (?)]), Libro de maravillas (Llibre de meravelles [1287-9 - Paris]), Libro de santa María (Llibre de santa Maria [1290-2 (?)]), Árbol de ciencia (Arbre de ciència; Arbor scientiae [29/9/I295-I/4/I296 - Roma]), Árbol de filosofía de amor (Arbre de filosofia d'amor [ı/_298 - París]), Libro del es de Dios (Liber de est Dei; Llibre de l'és de Déu [9/1300 Mallorca]), Libro de conocimiento de Dios (Llibre de coneixença de Déu [ı/ı3оo - Mallorca]), Libro de Dios (Llibre de Déu [12/I3оo - Mallorca]), Retórica nueva (Rhetorica nova [9/ı3OI Chipre]), Del nacimiento de Jesús infante (Liber natalis pueri parvuli Christi Jesu [I/I3II - París]), El fantástico (Liber disputationis Petri et Raimundi [Iо/I3I - París-Vienne]), Libro de virtudes y de pecados (Liber de virtutibus et peccatis sive Ars major praedicationis [I/I3I3 - Mallorca]) y La ciudad del mundo (Liber de civitate mundi [5/I3I4 - Messina]); para un total de 2532 ejemplos catalogados.

También han sido consultadas otras obras en las que propiamente no se han hallado ejemplos, son las siguientes: la Lógica nueva, el Libro de los artículos de la fe, el Libro de quédebe el hombre creer en Dios, el Tratado de astronomía y el Libro del orden de caballería (donde, sin embargo, cabe tener en cuenta el motivo del caballero perdido en el bosque del prólogo, por sus posibles implicaciones y relaciones con la narrativa breve medieval).

Así pues, en este momento el CEL ofrece y establece el corpus ejemplar luliano, que lógicamente habrá de sufrir las modificaciones, correcciones y/o adiciones habituales en este tipo de catálogos. Cada ejemplo ha sido titulado (he intentado que los títulos sean significativos y homogéneos). Cada ejemplo ha sido ubicado (siguiendo en cada obra la distribución por libros, capítulos, distinciones, etc., para intentar facilitar la confrontación de los ejemplos en otras ediciones). Finalmente, cada ejemplo presenta el tema que ilustra o explica. Simplemente con estos datos, el CEL permite rápidas búsquedas de conceptos y/o temas en las diferentes obras del mallorquín catalogadas.

A largo plazo, el objetivo del CEL es llegar a describir los elementos que conforman la literatura alternativa de Ramon Llull a través del estudio de sus ejemplos, tras haber definido cómo son (mediante resúmenes y/o la transcripción completa de cada ejemplo), cómo funcionan, cómo se reelaboran o se reutilizan y, cuando proceda, cómo cabe interpretarlos y si han utilizado materiales y/o motivos de la tradición; continuando con el modelo de estudio de cada ejemplo iniciado en mi tesis doctoral (Bonillo 20O7).

\section{Catálogo de Ejemplos Lulianos}

\section{I Libro de contemplación}

(I.2 - Llibre de contemplació en Déu; Liber contemplationis [1273-4 (?)]). Total ejemplos: IoI9. Carreras, Batllori, Carreras, Rubió i Balaguer, I957-I960, 2, 97-I269 [OE, 2, 97-I269]).

Título (distinción, capítulo, versículo: pág. Tema).

\section{Libro primero del volumen I}

I. $\quad$ El hombre que encontró una piedra preciosa (I,I,I: IO8. Encontrar a Dios).

2. El hombre que encontró un tesoro (I,I,2: IO8. Encontrar a Dios). 
3. El hombre en tierra extraña (I,I,4: IO8. Encontrar a Dios).

4. El placer de ver la naturaleza (I,2,4: IIO. La alegría de la existencia).

5. El hombre que soñó su muerte (I,2,7: IIO. La alegría de la existencia).

6. El borracho que olía a vino (I,2,8: IIo. La alegría de la existencia).

7. La alegría de las bestias (I,2,II: IIO. La alegría de la existencia).

8. El hombre que vio morir a su amigo (I,3,2I: II2. El beneficio de la muerte).

9. El agua que llena todo el jarrón (2,4,27: II4. La esencia de Dios).

Io. Los reyes que se humillan ante los viles (3,6,I7: Iı6. La humildad de Dios).

II. El hombre es tres cosas (5,II,II: I24. La Trinidad de Dios).

I2. El ángel es tres cosas (5,I2,3: I27. La Trinidad de Dios).

I3. La substancia del ángel (5,I2,4: I27. La Trinidad de Dios).

I4. La composición de los elementos (6,I5,8: I32. La creación).

I5. El grano de mostaza (6,I5,29: I34. La maldad de los pecadores).

I6. La restitución del cuerpo (6,I6,2: I34. El poder de Dios).

I7. La restitución de los átomos (6,I6,3: I34. El poder de Dios).

I8. La resurrección del cuerpo $(6,16,20$ : I35. El poder de Dios).

I9. El rey alegre (7,I9,7: I4O. La alegría de Dios).

20. La substancia del ángel (7,20,3: I 42. El conocimiento de Dios).

2I. Todas las montañas y las llanuras (7,22,6: I 46 . El conocimiento de Dios).

22. La descomposición del cuerpo (7,22,20: I47. La totalidad de los pecados).

23. La verdad de los vanidosos (8,24,I4: I5I. La verdad de Dios).

24. El árbol que crece (9,28,20: I59. La obra de Dios).

\section{Libro segundo del volumen I}

25. Los hombres que portan luz (IO,32,24: I67. El amor a los reyes).

26. La creación del sol (IO,32,25: I67. La iluminación de la cruz).

27. La lucidez y el calor del sol (IO,32,26: I67. Los que niegan la cruz).

28. El sujeto de la cualidad (IO,33,6: I68. La actividad de Dios).

29. El oro o la plata encontrados (IO,34,IO: I7O. El corazón de los avaros).

3O. El hombre hambriento o sediento (IO,34,25-6: I7 I. El corazón de los avaros).

3I. $\quad$ El avaro rico (IO,34,27: I7I. La pena eterna).

32. El árbol que se renueva (IO,35,I3: I72. Jesucristo).

33. Las aves migratorias (IO,35,I7: I72. La voluntad de Dios).

34. Las aves que van a los árboles en flor (IO,35,I8: I72. La devoción por la cruz).

35. Los vegetales en la tierra (IO,35,30: I73. La belleza de las estrellas).

36. Las aguas que bajan (IO,36,20: I74. El deber de alabar a Dios).

37. El marinero que trabaja (II,40,8: I82. La potencia vegetativa).

38. La potencia vegetativa (II,4O,23: I83. La potencia racional).

39. La potencia vegetativa (II,4O,24: I83. El otro mundo).

4O. Las viandas de la vegetativa (II,4O,25: I83. Los cuerpos glorificados).

4I. El desorden de la vegetativa (II,4O,26: I83. Los cuerpos descompuestos).

42. Los dos elementos ligeros (II,46,I7: I97. La primera intención).

43. Los dos elementos pesados (II,46,I8: 197. La segunda intención).

44. El hombre que dio un dinero (II,5O,23: 206. El mérito).

45. El mal hijo (II,5I,3O: 209. La franca voluntad).

46. La mar llena de agua (II, 53,20: 2I3. El origen del pecado).

47. Los que visten de rojo (II,58,I2: 223. El día del juicio). 
48. La leña que quema (I2,60,I3: 228. La Resurrección).

49. Las cosas bellas (I2,60,I4: 228. Jesucristo).

50. La muela que tritura el grano (I2,60,25: 229. La señal la cruz).

5. $\quad$ El molino de trigo (I2,60,26: 229. La pasión de Jesucristo).

52. El poder de las cosas ( $12,6 \mathrm{I}, 5: 23 \mathrm{O}$. El contraste a Dios).

53. La gota de agua (I2,6I,6: 230. La encarnación de Jesucristo).

54. Los cuerpos que cambian (I2,6I,I6: 230. La recreación de los hombres).

55. El injerto en un mal árbol (I2,6I,I7: 23O. Los pecados humanos).

56. La claridad del sol (I2,6I,I8: 230. El pecado original).

57. Los hombres que compran (I4,68,6: 245. Los atributos de Dios).

58. El hombre que compra un esclavo (I4,68,8: 245. La libertad de pecar).

59. El precio del pueblo (I4,68,IO: 245. El servicio a Dios).

6o. Los ríos que van al mar (I5,7O,I: 248. La sabiduría de Dios).

61. El buen maestro albañil (I5,70,I6: 249. La sabiduría de Dios).

62. El sol del mediodía (I5,7O,23: 250. La sabiduría de Dios).

63. El pobre y el rico que hacen caridad (I6,74,8: 257. La humildad).

64. El rico que ignora a Dios (I6,74,I7: 258. La riqueza real).

65. Los señores vanagloriosos (I6,74,23: 258. La riqueza real).

66. Los hombres falsos y desleales (I6,75,I5: 260. El entendimiento).

67. El hombre injurioso y falso (I6,75,22: 260. La lealtad).

68. Los señores viles y mezquinos (I6,76,23: 262 . La nobleza de Dios).

69. El príncipe generoso (I7,8I,23: 272. La generosidad de Dios).

7O. La lluvia que nutre la tierra (I7,82,I3: 273. La satisfacción en Dios).

7I. La tierra nutrida por la lluvia (I7,82,I4: 273. La alabanza a Dios).

72. Los hombres misericordiosos (I8,84,IO: 277. El otro mundo).

73. El mal rico y el silo de trigo (I8,84,28: 278. La confianza en Dios).

74. La nave que vara (18,85,5: 279. La ayuda de Dios).

75. El león que no puede con diez hombres (I8,85,6: 279. La ayuda de Dios).

76. El fuego y el aire van hacia arriba (I8,86,8: 28I. La ayuda de Dios).

77. El entendimiento de la Encarnación (I9,87,28: 285. La humildad de Dios).

78. El pobre que se humilla ante el rico (19,88,21: 286. La gloria de Dios).

79. El fruto del buen árbol (19,89,2: 287. La palabra de Dios).

8o. Los señores muertos en batalla (I9,9O,I3: 290. La muerte de Jesucristo).

8I. Los ricos vanagloriosos (I9,90,20: 290. La muerte de Jesucristo).

82. El barco cargado (19,9O,30: 29I. La muerte de Jesucristo).

83. Los hombres orgullosos (19,92,6: 294. La humildad de Dios).

84. Los señores a quienes ruegan (19,92,25: 295. La bienaventuranza de Dios).

85. Los rayos del sol no se ensucian (20,93,20: 297. La misericordia de Dios).

86. Los rayos del sol lo baten todo (20,93,2r: 297. La misericordia de Dios).

87. El gran fuego que no se apaga con agua (20,93,22: 297. La misericordia de Dios).

88. El hombre calentado por el sol (20,93,23: 297. La cruz).

89. La serpiente que envenenó a un ciervo (20,93,24: 297. La misericordia de Dios).

90. La nave que soporta el mal tiempo (20,93,26: 297. La misericordia de Dios).

9I. El pez en el agua (20,93,27: 297. La misericordia de Dios).

92. La columna que sostiene el albergue (20,94,25: 299. La misericordia de Dios).

93. La nave que soporta el mal tiempo (20,95,22: 30I. La misericordia de Dios).

94. El hombre que agoniza (20,95,27: 30I. La misericordia de Dios). 
95. El pollito que perseguía a la gallina (20,96,25: 304. La misericordia de Dios).

96. El hombre que se calentaba al fuego (21,97,5: 304. La gloria de Dios).

97. Los pobres que hablan con los ricos (21,97,27: 306. La gloria de Dios).

98. La lluvia que cae en la tierra (22,IOI,4: 3I3. La obra de Dios).

99. Los sentidos corporales y espirituales (22,IOI,I3: 3I4. La obra de Dios).

IOO. El hombre sin ojos (22,IOI,I5: 3I4. El conocimiento de Dios).

IOI. El hombre que viajó por todo el mundo (22,IOI,25: 3I5. La obra de Dios).

IO2. Los que alaban a los hombres honrados (22,IOI,27: 3I5. La obra de Dios).

IO3. La gallina que picotea el trigo (22,IO2,24: 3I7. La perfección de Dios).

IO4. La sequía (22,IO2,26: 3I7. La perfección de los hombres).

IO5. La lluvia abundante (22,IO2,26: 3I7. La perfección de Dios)

\section{Libro tercero del volumen II}

Io6. El atavío de los reyes (23,IO3,2: 318. La suciedad de las mujeres).

IO7. El nacimiento de los hombres (23,IO3,4: 3I8. El nacimiento de las bestias).

Io8. Las bestias que nacen sin pecado (23,IO3,5: 3 I8. El pecado original).

Io9. Les bestias que nacen fuertes $(23, \mathrm{IO} 3,6$ : $3 \mathrm{I}$ I8. La debilidad de los hombres).

IIO. Los recién nacidos sucios (23,IO3,7: 318. La suciedad de los hombres).

III. Los que nacen sin nada (23,IO3,I5: 3I9. La muerte).

II2. Los hombres y la belleza material (23,IO4,9: 320. La belleza espiritual).

II3. Los excrementos del huerto (23,IO4,IO: 32O. La suciedad del pecado).

II4. El árbol seco (23,IO4,23: 32I. El perdón de los pecados).

II5. La ropa manchada (23,IO4,24: 32I. La suciedad del pecado).

II6. El hombre que hizo un palacio (23,IO4,25: 32г. La imaginación).

II7. El hombre que guarda cosas bellas del palacio (23,IO4,26: 32I-2. Los cimientos).

II8. Los poderosos que hacen cosas bellas (23,IO4,27: 322 . La vanagloria).

II9. El honrado y la mujer del espejo (23,IO4,28: 322. La cruz).

I2O. La presencia del sol (23,IO5,4: 322. Los vicios y las virtudes).

I2I. El árbol que cambia de color (23,IO5,II: 323. La incerteza).

I22. El fuego que calienta el agua (23,IO5,I9: 323. Los mentirosos).

I23. Los ojos corporales (23,IO6,7: 325. La esencia de Dios).

I24. Los árboles que mudan (23,IO7,2: 327. La intención).

I25. Los frutos del árbol (23,IO7,7: 327. La hipocresía).

I26. Los lobos con piel de oveja (23,IO7,7: 327. La hipocresía).

I27. Los frutos del árbol (23,IO7,9: 327. La gloria).

I28. Los árboles frondosos (23,IO7,II: 327. La gloria).

I29. Los árboles que no dan frutos (23,IO7,I3: 328. La acidia).

I3O. El calor del sol (23,IO7,I6: 328. La pasión de Jesucristo).

I3I. La frialdad del invierno (23,IO7,I7: 328. Los pecadores).

I32. El buen árbol y el bello (23,IO7,I8: 328. Los virtuosos).

I33. Los árboles que florecen (23,IO7,I9: 328. Las buenas obras).

I34. Los árboles que no dan frutos (23,IO7,2O: 328. Las buenas obras).

135. Los árboles que se renuevan (23,IO7,23: 328. La renovación del mundo).

I36. Las plantas que se nutren (23,IO7,24: 328-9. El amor a Dios).

I37. Los árboles generados (23,IO7,25: 329. La vanidad).

I38. La apariencia de los árboles (23,IO7,26: 329. La hipocresía).

I39. Los animales herbívoros (23,I08,I: 329. El ejemplo divino). 
I4O. La sabiduría de las hormigas (23,IO8,2: 329. Las buenas obras).

I4I. Las bestias salvajes (23,IO8,3: 329. El refugio divino).

I42. Las bestias que combaten (23,I08,4:329. La tentación).

I43. Las bestias que se defienden con los dientes (23,I08,4: 329. La mentira).

I44. Las bestias que se defienden con las uñas (23,IO8,4: 329-3O. La codicia).

I45. Las bestias que caminan (23,I08,5: 330. La gloria).

I46. Las bestias que descansan (23,I08,6: 33O. La gloria).

I47. El rey de las bestias (23,I08,7: 330. La necesidad de los reyes).

I48. El león sometido al asno (23,I08,8: 330. El alma y el cuerpo).

I49. Las bestias de carga (23,IO8,IO: 33O. Los oficios).

I5O. Los carniceros de bestias (23,I08,I2: 330. La memoria).

I5I. El can raro en la corte del rey (23,I08,I3: 330. Morir en pecado).

I52. Las bestias que se esconden por miedo (23,IO8,I4: 330. La hipocresía).

I53. El fajo de las bestias (23,IO8,I5: 330. La cruz).

I54. Las aves (23,IO9,I: 332. Las buenas obras y las malas).

I55. El halcón que vence a la grulla (23,I09,3: 332. Vencerse a uno mismo).

I56. El pájaro que se vence (23,Io9,4: 332. Vencerse a uno mismo).

I57. Los pájaros que vencen a grandes aves (23,IO9,6: 332. La potencia racional).

I58. El águila que vuela hacia el cielo (23,I09,7: 332. La vanidad).

I59. Las palomas y el azor (23,IO9,8: 332. Los ricos y los pobres).

I6o. El águila es la reina de las aves (23,IO9,9: 332. La nobleza de Dios).

I6I. El buitre que buscaba vianda (23,IO9,IO: 332. Los pecadores).

I62. Las aves migratorias (23,IO9,II: 332. La vanidad).

I63. La gallina que comía de todo (23,Io9,I2: 332. La nobleza).

I64. Las viandas de las aves (23,I09,I3: 332-3. La nutrición).

I65. Las aves que nutren (23,I09,I4: 333. La nutrición).

I66. Las aves que vuelan (23,Io9,I5: 333. El paraíso y el infierno).

I67. El azor y el gavilán (23,IO9,I6: 333. El libre albedrío).

I68. El halcón que perseguía la grulla (23,Io9,I7: 333. El servicio a Dios).

I69. El rey que no alimenta su halcón (23,I09,I7: 333. El designio divino).

I7O. Los gallos que cantan (23,Io9,I8: 333. La gloria de Dios).

I7I. El ruiseñor y su jaula (23,IO9,I9: 333. La gloria de Dios).

I72. El pazguato del parador de pájaros (23,IO9,20: 333. La cruz).

I73. El señor que tomaba aves de la alambrada (23,Io9,2I: 333. El demonio).

174. Los pájaros en Pascua (23,Io9,23: 333. La Cuaresma).

I75. Los afanes de pájaros y bestias (23,I09,24: 333-4. La contemplación de Dios).

I76. La garza que huye del halcón (23,I09,25: 334. Pensar en Dios).

I77. La abeja que fabrica miel y cera (23,Io9,26: 334. La gloria de Dios).

I78. El azor que se detenía en la mano (23,I09,27: 334. El martirio de Dios).

I79. Los pájaros y las aves (23,Io9,29: 334. La cruz).

I80. Las aves que renuevan sus plumas (23,I09,30: 334. La esencia de Dios).

I8I. El papa de Roma (23,IIO,3: 334. La unidad de Dios).

I82. La bestia atada por el cuello (23,IIO,I9: 334. Los religiosos).

I83. Los hombres nobles (23,III,3: 336-7. El honor a Dios).

I84. Los reyes y los príncipes (23,III,I6: 338. La plenitud de los hombres).

I85. Los caballeros mundanales (23,II2,6: 339. La caballería celestial).

I86. El caballero vencedor y vencido (23,II2,9: 340. La misericordia). 
I87. Los caballeros que combaten a los infieles (23,II2,29: 34I. Los religiosos).

I88. Los caballeros guarnecidos (23,II2,3O: 34I. La tentación).

I89. Los malos jueces y los malos abogados (23,II4,I5: 345. La ceguera).

I9O. El mercader sabio (23,II6,2: 349. La gloria).

I9I. El buen mercader (23,II6,3: 349-50. El pecado original).

I92. Los marineros que llevan el timón (23,II7,2: $35^{2}$. La gloria).

I93. Los marineros que despliegan las velas (23,II7,3: $35^{2}$. La cruz).

I94. Los corsarios (23,II7,5: 353. La gloria).

I95. Los anzuelos de los pescadores (23,II7,7: 353. La gloria).

I96. El nauclero de los marineros (23,II7,IO: 353. El entendimiento del alma).

I97. Los marineros sabios (23,II7,I5: 353. La gloria).

I98. Las naves que combaten el mal tiempo (23,II7,I8: 354. El espíritu).

I99. Los malos marineros (23,II7,I9: 354. La reverencia a Dios).

200. Las naves cargadas de mercaderías (23,II7,20: 354. El provecho).

2OI. La sentina de la nave (23,II7,2I: 354. Los hombres).

202. Los marineros que se lanzan al mar (23,II7,22: 354. La misericordia).

203. Los sabios marineros que vigilan (23,II7,23: 354. La vanidad).

204. Los marineros muertos en el mar (23,II7,24: 354. El alma).

205. La vianda de los marineros (23,II7,25: 354-5. La gloria).

206. La nave en peligro (23,II7,26: 355. La salvación).

207. Los marineros de mal agüero (23,II7,27: 355 . El entendimiento).

208. La nave mal aparejada (23,II7,28: 355. Los hombres).

209. Los marineros muertos en el mar (23,II7,30: 355. La salvación).

2IO. Los pastores que protegen su ganado (23,II9,I: $35^{8}$. El pecado).

2II. Las bestias que obedecen al pastor (23,II9,2: $35^{8}$. Los hombres).

2I2. El pastor que pierde una oveja (23,II9,4: $35^{8}$. El pecado).

2I3. El pastor que guarda el ganado (23,II9,5: 358. Los sentidos).

2I4. El pastor que guía por malos pastos (23,II9,6: 358. Los sentidos).

2I5. El pastor que duerme cuando viene el lobo (23,II9,IO: 359. La vanidad).

2I6. El pastor que se protegía del frío (23,II9,IO: 359. Pasar cuentas).

2I7. El bastón torcido del pastor (23,II9,I4: 359. La cruz).

218. El buen pastor (23,II9,I7: 359. La bienaventuranza).

219. El pastor que sanaba el ganado (23,II9,I8: 359. La bienaventuranza).

220. El ganado que no obedecía al pastor (23,II9,I9: 359. El tormento).

22I. Las bestias que huyen del pastor (23,II9,20: 359. El demonio).

222. La imagen pintada o esculpida (23,I2O,3: 360-I. Las obras).

223. El hombre desnudo al sol (23,I2O,7: 36r. El cuerpo glorioso).

224. Los labradores que hacen barbecho (23,I2I,2: 363 . Los pobres y los ricos).

225. Los labradores que siembran (23,I2I,4: 363 . Las obras).

226. El labrador loco (23,I2I,5:363-4. La finalización).

227. Las obras de los labradores (23,I2I,7: 364 . Los vicios).

228. La siega y la batida del trigo (23,I2I,8: 364 . El fuego infernal).

229. El abono de la tierra (23,I2I,II: 364 . La gloria).

23O. Los labradores que conocen la tierra (23,I2I,I2: 364. La bondad de Dios).

23I. Los labradores que necesitan la lluvia (23,I2I,I3: 364. Los malos hombres).

232. Los labradores desagradecidos (23,I2I,I4: 364. La justicia).

233. El envilecimiento del arte de labrar (23,I2I,2O: 365. La pasión). 
234. Los tenderos que venden cosas (23,I22,I3: 367 . La gracia).

235. El molinero que pica (23,I22,I4: 367 . El cuerpo de Dios).

236 . El vidriero que fabrica $(23, \mathrm{I} 22, \mathrm{I} 5: 367$. La divinidad).

237. Los alfareros y los olleros trabajan con tierra (23,I22,I6: 367. La pasión).

238. El hornero que no quema el pan (23,I22,I7: 367. El cuerpo de Cristo).

239. Los alguaciles que condenan (23,I22,2I: 368 . El alma).

240. Los arrieros y sus bestias (23,I22,25:368. El fajo de los hombres).

24I. El ballestero que se da coraje (23,I22,27: 368 . La pasión).

242. El oficio de corretería (23,I22,28: 368. La gracia).

243. Los calafateadores que colocan estopa (23,122,29: 368-9. El cuerpo de Cristo).

244. Los mozos que llevan fajos (23,I22,30: 369 . La gloria).

245. Las riquezas de los pecadores (23,I23,6: 369 . La cruz).

246. El brillo del sol (23,I23,I5: 369-7O. La cruz).

247. La rosa roja y el lirio blanco (23,I23,22: $37 \mathrm{O}$. La cruz).

248. El sol que agrieta la tierra (23,I23,28: 37O. La cruz).

249. La visión del brillo del sol (23,I23,29: 37O. La cruz).

250. Las imágenes en el espejo (23,I24,7: 372. Los ojos espirituales).

25I. La vista de la nave (23,I24,8: 372 . Los ojos espirituales).

252. La claridad del sol que cierra los ojos (23,I24,I3: 372. Los ojos espirituales).

253. Las orejas que escuchan (24,I25,3: 374. Los oídos del corazón).

254. La música que alegra (24,I25,5:374. El alma).

255. El que escucha penas (24,I25,7: 374. El oído espiritual).

256. El oído que oye las voces (24,I25,8: 375. El oído espiritual).

257. El oído que no oye de lejos (24,I25,9: 375. El oído espiritual).

258. Las mentiras que llegan a las orejas (24,I25,23: 376 . El oído intelectual).

259. Los hombres que niegan a $\operatorname{Dios}(24, \mathrm{I} 26,25: 379$. El oído).

260. El sol que ilumina y nutre la tierra (24,I26,27: 379. La falta de Dios).

26I. El cuchillo que se arroma (24,I27,I6: 380. Los sentidos).

262. El cuchillo que se afila (24,I27,I6: 380 . El entendimiento).

263. Los vermes que consumen el cuerpo (24,I27,20: 38I. La vanagloria).

264. El límite del oído (24,I27,22: 38I. El entendimiento del alma).

265. El comienzo del oído (24,I27,27: 381. La finalidad).

266. La extensión del oído (24,I27,28: 38г. El entendimiento del alma).

267. El placer de los buenos olores (25, I28,I: 382 . El entendimiento del alma).

268. La corrupción de los malos olores (25,I28,9: 382. El alma).

269. La habitación ambientada (25,I28,2I: 383 . La suciedad del cuerpo).

270. El hombre enfermo (26,129,5: 384. El alma).

27I. El gusto contrastado (26,I29,6: 384. El gusto intelectual).

272. La función del gaznate (26,129,8: 384. El corazón).

273. El placer del gaznate (26,129,9: 384-5. Dios).

274. La aguja que gira hacia el norte (26,I29,I9: 385 . El dolor).

275. Las bestias necesitan carne fresca (26,129,21: 385 . Los pecadores).

276. El alma que se separa del cuerpo (26,129,24: 386. La gloria del cuerpo).

277. El cumplimiento del gusto (26,I29,25: 386 . El cuerpo).

278. El frío por la falta de sol (27,I3O,IO: 387 . La falta de Dios).

279. El que se acerca a la nieve o al fuego (27,I3O,II: 387 . La gloria).

280. El enfermo que se calienta al fuego (27,I30,20: 388 . El amor a Dios). 
28I. El sol que calienta la tierra (27,I3O,2I: 388. La recreación).

282. El frío invernal (27,I3O,22: 388. La cruz).

283. El frío de los pobres en invierno (27,I30,23: 388. La vanagloria).

284. Los hombres negros por el sol (27,I30,24: 388. El amor a Dios).

285. El que saca el corazón a una bestia muerta (27,I30,25:388-9. El amor a Dios).

286. La piedra de mármol (27,I30,25: 389. El amor a Dios).

287. El hombre que explica su languidez (27,I3I,I: 389. La contrariedad).

288. El rico que satisface su cuerpo (27,I3I,2: 389. La potencia vegetativa).

289. Los graneros de los ricos (27,I3I,6: 389. Jesucristo).

290. Los marineros y el agua del mar (27,I3I,7: 389-90. Los ricos y los pobres).

29I. Los hombres que se protegen en un castillo (27,I3I,I9: 389-90. La pasión).

292. El sediento satisfecho en una bella fuente (27,I3I,20: 390. El sacrificio).

293. El hombre sano (27,I32,I: 392. El alma).

294. El cuerpo que enferma (27,I32,5:392. El alma).

295. La salud del cuerpo (27,I32,7: 392. El alma).

296. El enfermo agonizante que llamó al médico (27,I32,30: 394. El alma).

297. El cansancio del cuerpo (27,I33,2: 394. El alma).

298. El reposo del cuerpo (27,I33,3: 394. El alma).

299. El reposo del cuerpo y los elementos (27,I33,6: 394. El alma).

300. El placer del alma (27,I34,I: 396. El placer del cuerpo).

30I. La naturaleza del placer del cuerpo y del alma (27,I34,3: 397. El placer).

302. El placer de los religiosos (27,I34,IO: 397. El placer).

303. El placer de los hombres en Pascua (27,I34,I3: 397. El error contra Dios).

304. Las ruinas de la casa (27,I34,I6: 398. El placer).

305. El hombre comilón (27,I35,I6: 400. La diligencia y la pereza).

306. El perezoso que se acuesta (27,I35,I7: 400. La diligencia de Dios).

307. El perezoso que se acuesta y bosteza (27,I35,25: 40O-I. La pereza del alma).

308. Las espuelas y agujas para las bestias (27,I35,26: $4 \mathrm{OI}$. La pereza del alma).

309. Los hombres negligentes (27,I35,28: 4OI. Las buenas obras).

3IO. El hombre que añora entre enemigos (27,I36,5: 4OI. El alma).

3II. El hombre y la mujer que se añoran (27,I36,II: 4O2. El deseo de Dios).

3I2. El hombre vencido por el enemigo (27,I36,I2: 4O2. La ayuda de Dios).

3I3. El recién nacido que gatea (27,I36,24: 403. El deseo de Dios).

3I4. El rey que deseaba guerreros osados (27,I37,8: 4O4. La primera intención).

35. Los guerreros que se sacrifican o huyen (27,I37,2I: 4O5. El amor a Dios).

316. Los señores de los guerreros muertos en batalla (27,I37,25: 404. El amor a Dios).

317. El hombre que perdió la osadía en la batalla (27,I37,26: 404-5. El amor a Dios).

3I8. El guerrero flaco (27,I37,28: 406. La ayuda de Dios).

39. El hombre que cabalga satisfecho (27,I38,6: 406. La vergüenza).

320. La familia en su albergue (27,I38,7: 406. La vergüenza).

32I. El ciego que vagaba por el desierto (27,I39,6: 409. Los celos).

322. La buena mujer que no quería un marido celoso (27,I39,I2: 4IO. Los celos).

323. El viejo celoso casado con una joven (27,I39,I5: 4IO. Los celos).

324. Los maridos que obligan a mentir a las esposas (27,I39,I8: 4IO. Los celos).

325. Los bellos ornamentos (27,I39,2I: 4IO. Los celos).

326. El mundo orgulloso (27,I4I,I4: 4I5. El otro mundo).

327. El que mató a una leona preñada (27,I4I,I7: 4I5. El orgullo). 
328. El enfermo que quería sanar (27,I42,30: 418. El pecador).

329. El cojo que tropezaba (27,I43,6: 4I9. La lujuria).

33O. El pez bajo el agua (27,I43,II: 4I9. La lujuria).

33I. El escarabajo que busca la suciedad (27,I43,I6: 420. La lujuria).

332. El cerdo que se satisface en el estiércol (27,I43,I7: 420. La lujuria).

333. El gran fuego que se apaga con agua (27,I43,29: 42I. La lujuria).

334. El agua que da vida a la naturaleza (27,I43,30: 42I. La lujuria).

335. La mar turbada por el viento (27,I44,4: 42I. La ira).

336. El borracho que perdió la cabeza (27,I44,6: 42I. La ira).

337. La naturaleza destructiva del fuego (27,I44,I3: 422. La ira).

338. La chispa de fuego que crece (27,I44,I4: 422. La ira).

339. El religioso que observa la cruz (27,I47,5: 428. Los sentidos).

340. El presbítero que tenía el cuerpo de Dios (27,I47,9: 428. Los sentidos).

34I. La casa con dos puertas (27,I47,I3: 428. Los sentidos).

342. Los pobres que van a casa de los ricos (27,I47,26: 429. Los sentidos).

343. Los deleites del cuerpo (27,I47,29:430. El alma).

344. La bestia atada (27,I48,7: 430. Los sentidos).

345. Las aves que vuelan por los aires (28,I 49,8: 432. Pensar en Dios).

346. Los árboles que necesitan agua (28,I49,23: 434. El alma).

347. La memoria de los hombres (28,I50,5: 435. Pensar en Dios).

348. Nadar en el agua y volar por el aire (28,I5O,28: 437. Pensar en Dios).

349. Los peligros de la tempestad (28,I5O,29: 437 . El alma).

350. Los pájaros que anidan en los árboles (28,I5O,30: 437. El alma).

35. Los hombres que disputan por sus obras (28,I52,23: 44I. Los ángeles).

352. El fuego es el elemento principal (28,I54,I2: 445 . La fe).

353. El hombre que separa el grano de la paja (28,I55,I2: 448. La verdad).

354. La forma del caballo y la del asno (28,I56,7: 450. La servidumbre de los hombres).

355. El carpintero que daba forma a la madera (28,I56,IO: 45 o. La servidumbre de los hombres).

356. El hombre que tenía necesidades corporales (28,I56,20: 45 I. El alma).

357. El sol que acaba con el rocío (28,I58,I5: 455. La pasión).

358. El hombre que hablaba con sofismas (28,I58,17: 455. Los malos pensamientos).

359. El sabio que huía de los sofismas (28,I58,I8: 455. Los malos pensamientos).

36o. El ciego que erró el camino (28,I58,23: 456. Los malos pensamientos).

36r. El bastón y el guía del ciego (28,158,24: 456. Los malos pensamientos).

362. La ciudad sitiada (28,I58,25: 456. Los malos pensamientos).

363. Las palabras desordenadas del loco (28, I58,27: 456. Los malos pensamientos).

364. La jarra llena de agua (28,I59,I3: 458. Las penas infernales).

365. El hombre con fiebre sin remedio (28,I59,I7: 458. Las penas infernales).

366. El hombre herido que perdió la cabeza (28,I59,I8: 458. Las penas infernales).

367 . El fuego que quema la leña $\left(28, \mathbf{I} 59,23: 45^{8}\right.$. Las penas infernales).

368. El hierro en la fragua (28,I59,25: 459. Las penas infernales).

369. Los ojos que no soportan la luz del sol (28,I59,28: 459. Las penas infernales).

370. La nave que se hunde (28,I60,2: 459. La muerte del cuerpo).

37I. El loco por la fiebre (28,I6I,I8: 463. La memoria).

372. Los ojos que perciben los colores (28,I62,I2: 465 . El entendimiento).

373. Los ojos que perciben las figuras (28,I62,I4: 465 . El entendimiento).

374. Los cuerpos que obstaculizan la visión (28,I62,I5: 465. El entendimiento). 
375. Los ojos tapados por los cuerpos (28,I62,I6: 465 . El entendimiento).

376 . El pescador que pesca con pesos (28,162,I8: 465-6. El entendimiento).

377. El timón que salva la nave en la tempestad (28,I62,23: 466. El entendimiento).

378. El vasallo orgulloso de su buen señor (28,I62,26: 466 . El entendimiento).

379. La materia, la forma y la substancia (28,I65,I2: 473 . Las virtudes del alma).

380. Los tres lados del triangulo (28,I65, I9: 474. Las virtudes del alma).

38I. La forma de la materia $(28,165,20: 474$. Las virtudes del alma).

382 . La disposición del firmamento $(28,165,27$ : 474 . Las virtudes del alma).

383. El agua sucia y fangosa (28,I66,22: 476 . Los sentidos).

384. La escalera que sube y baja (28,I67,2r: 479. Los sentidos y el entendimiento).

385. El ave en el cielo (28,I68,7: 480-I. La terminación).

386. El hombre que carga un fajo (28,I68,I7: 48I. El alma).

387. La piel que se estira y se encoge (28,I68,I9: 48I. El alma).

388. El pájaro que vuela por los aires (28,I68,2r: 482. Pensar en Dios).

389. El extranjero que visita el palacio del rey (28,I68,22: 482. Pensar en Dios).

390. El escarabajo apestoso (28,168,26: 482. La vanidad).

39I. El espejo torcido (29,I69,2: 483. Los sentidos).

392. La mujer que buscaba un espejo (29,169,3: 483. Los sentidos).

393. El hombre que entiende cuando oye una palabra (29,169,4:483. Los sentidos).

394. Los ojos que distinguen figuras y colores (29,I69,5:483. El alma).

395. El propósito del maestro de la nave (29,I69,7: 483. Los sentidos y el entendimiento).

396. El maestro que estudia la madera (29,I69,8: 483. Los sentidos y el entendimiento).

397. Los caballeros que conocen al rey (29,I69,II: 484. Las virtudes del alma).

398. La naturaleza del fuego y del agua (29,170,25: 489. El entendimiento).

399. El grano de trigo (29,I7I,IO: 49I. Los milagros).

400. La mujer que podía engendrar (29,I7I,II: 49I. Los milagros).

4OI. Los injertos de los vegetales (29,I7I,I3: 49I. La naturaleza).

4O2. El caballo y la burra (29,I7 I,I4: 49I. La naturaleza).

403. La naturaleza del fuego y del agua (29,I7I,IO: 49I-2. La naturaleza).

4O4. El hombre que no podía caminar (29,I7 I,25: 492. La naturaleza).

405. El hombre que movía los pies (29,I7I,26: 492. La naturaleza).

406. El hombre que no podía caminar (29,I7I,25: 492. La naturaleza).

407. El pan y el vino (29,I72,26: 496. La comunión).

408. Los dos espejos encarados (29,I74,6: 5OI. Las virtudes del alma).

409. El objeto ante el espejo (29,I74,7: 5OI. El alma).

4IO. El espejo pequeño ante el grande (29,I74,8: 5OI. El alma).

4II. El espejo torcido (29,I74,6: 5O2. El alma).

4I2. El género y la especie del hombre (29,I75,I6: 5O5. La posibilidad).

4I3. El hombre y las figuras Ay B (29,I75,27: 506 . El conocimiento).

4I4. La cantidad finita del firmamento (29,I76,22: 5I. La infinitud).

4I5. El espejo no refleja lo que se halla tras de sí (29,I77,I5: 5³. La conjunción).

4I6. El hijo en el vientre de la madre (29,I77,2O: 5I3. El conocimiento).

4I7. Los peces viven en el agua y nadan (29,I77,23: 5I3-4. El alma).

4I8. El rey y el príncipe misericordiosos (29,I78,2I: 5I3. El comienzo).

4I9. El resplandor del sol (29,I78,23: 5I3. La humildad).

420. La piedra y la madera (29,I79,2I: 52I-522. La Trinidad).

42I. El príncipe honrado (29,I84,29: 536. La Encarnación). 
422. El espejo claro (29,I85,3: 539. Las virtudes divinas).

423. El cuchillo hecho para cortar (29,185,4: 540. Las virtudes divinas).

424. La finalidad de las cosas $(29,185,5: 540$. Las virtudes divinas).

425. Las virtudes de los animales y de los vegetales (29,I85,6: 540. Las virtudes divinas).

426. El resplandor del sol (29,185,7: 540. Las virtudes divinas).

427. El rey noble y sabio (29,I85,9: 540. Las virtudes divinas).

428. La belleza de las obras (29,I85,I2: 540-54I. Las virtudes divinas).

429. El agua sucia (29,I85,I6: $54 \mathrm{I}$. El amor).

430. El hombre enamorado (29,I85,I9: 54I. El amor).

43I. La mujer que dirige (29,I87,I2: 548. La verdad).

432. La pieza de oro y la piedra (29,187,20: 549. Los artículos de la fe).

433. Las falsas proposiciones (29,I87,2I: 549 . El pecado).

434. El espejo más claro (29,I88,2: 550. Las virtudes divinas).

435. El hombre ciego (29,I88,30: 553. La ley).

436. Las vías sensuales (29,I89,5: 554. Las virtudes divinas).

437. El movimiento del sol (29,I9I,I: 560. El pecado).

438. El calor del sol (29,I9I,I: 56o. El pecado).

439. El color del agua y del gusano (29,I9I,3: 56o. El pecado).

440. El esclavo sometido al señor (29,I9I,2I: 562 . Las potencias).

44I. La mayor claridad y el mayor calor del fuego (29,I92,3: 565. El bien y el mal).

442. Los dos testimonios (29,193,6: 567 . Las potencias del alma).

443. Las obras del hombre virtuoso (29,I93,28: 569. El intelecto).

444. El agua que acaba con el fuego (29,I94,6: 570. La potencia racional).

445. El espejo torcido (29,I94,30: 573. La potencia sensitiva).

446. El espejo verdadero (29,194,30: 573. La potencia racional).

447. El rayo de sol (29,195,4-5: 574. La corrupción).

448. El rayo de sol (29,195,6: 574. La substancia de Dios).

449. El peso de la balanza (29,200,3: 589. El orden).

45O. Los dos espejos encarados (29,200,24: 59I. La contemplación).

45I. La voluntad del platero (29,202,3: 596. El amor y el desamor).

452. La demostración del cristal (29,202,2: 598 . La lealtad y la falsedad).

453. El espejo que representa la figura $\left(29,202,3: 59^{8}\right.$. La lealtad).

454. Los animales engendran otros animales (29,202,I5: 599. La lealtad).

455. El calor y la sequedad (29,202,I8: 6oo. La lealtad).

456. La envidia del hombre falso (29,202,23: 6oo. La falsedad).

457. El barco lleno o vacío $(29,205,4$ : 605. Los cinco sentidos).

458. El bello árbol (29,205,5: 605. El cuerpo del hombre).

459. El barco lleno de agua (29,205,I6: 6o6. El alma).

460. El espejo acabado (29,205,I7: 6o6. El acabamiento).

46I. El buen olor (30,207,I5: 6II. Los deleites).

462. El príncipe loco y corrupto (30,207,I9: 6I4. La conciencia).

463. El hombre en el precipicio (3O,2I2,IO: 625. La corrupción).

464. El debilitamiento del cuerpo humano (30,2I2,II: 625. La conciencia).

465. La vista corporal (30,2 I3,3: 627. La conciencia).

466. El vientre del hombre hambriento (3I,2I6,29: 638. El entendimiento).

467. Los hombres que viven en las montañas (3І,216,30: 638. La sabiduría).

468. La vista corporal (3I,2I9,3: 645. La sutileza). 
469. El pez en la mar (3I,2I9,9: 646. La sutileza).

470. El barco vacío o aparejado (32,220,4: 648. El coraje).

47I. La hormiga que carga peso (32,220,2I: 650 . El coraje).

472. El hombre dolorido (32,220,22: 650. La animosidad).

473. El médico que cura (32,22I,3: 65I. La animosidad).

474. La multitud de leña (32,22I,26: 653. La potencia imaginativa).

475. El fuego pequeño $(32,22 \mathrm{I}, 27: 653$. La potencia imaginativa).

476. El hombre que pierde el sentido (32,222,2: 654. La ordenación).

477. El miedo del hombre que pierde la cabeza (32,222,II: 655 . El fervor).

478. El acólito preparado (32,222,I5: 655. La animosidad).

479. El hombre encarcelado (32,222,I8: 656. El coraje).

480. El hombre enamorado (32,223,I5: 658. El alma).

48I. El buen combatiente (32,223,27: 659. Morir por Dios).

482. El hombre que se mira en el espejo (32,223,29: 659. La gloria).

483. La forma y la materia $(32,224,3: 659-660$. El coraje).

404. El vasallo fiel (32,224,II: 66o. La honra).

485. El mal vasallo (32,224,25: 662. La honra).

486. El cuerpo que se mueve (32,225,2: 662. El alma).

487. Los dos pies (32,225,9: 663. El alma).

488. El hombre que camina de espaldas (32,225,I2: 663. El alma).

489. El hombre que va al río (32,225,I5: 663. La misericordia).

490. El fuego que purifica el oro $(32,225,23: 664$. La paciencia).

49I. El agua que purifica $(32,225,26: 664$. El alma).

492. El hombre ciego y sordo (32,226,22: 667. La Trinidad y la Encarnación).

493. El hombre que conocía por los sentidos (32,226,23: 667. La fe).

494. El lapidario y la piedra preciosa (32,226,24: 667. La animosidad).

\section{Libro cuarto del volumen III}

495. El herrero y la forma (33,228,24: 674. La potencia y el acto).

496. El menestral y su obra (33,228,5: 674. Las artes).

497. El herrero que fabrica cuchillos (33,228,6: 674 . La forma).

498. La pieza del herrero (33,228,8: 674. La forma y el acto).

499. La materia del herrero (33,228,I2: 675. La forma).

50o. La materia elemental (33,228,28: 677. El alma).

5OI. Los cuatro elementos (33,228,29: 677. El alma).

502. La propiedad de la materia y de la forma (33,228,30: 677. El alma).

503. El botero que no sabe hacer naves (33,229,4: 678. La imposibilidad).

504. La materia del carpintero (33,229,5:678. La privación).

505. La forma del pan (33,229,6: 678. La forma del hombre).

506. El hombre lógico (33,229,I6-I9: 679-68o. La imposibilidad).

507. El hierro que corta (34,230,13: 684. El oro).

5o8. El maestro que hace una nave (34,230,I6: 684-685. La figura).

509. El maestro que hace una nave (34,230,I7: 685. La creación).

5 IO. La materia de la nave (34,23I,I8: 688. La forma).

5II. Los filósofos (34,23I,I9: 688. La materia corporal).

5 ${ }^{\text {I2. }}$ La materia del vaso de plata (34,231,23: 689. La materia sensual).

5I3. La longitud y la amplitud (34,23I,29: 690. El alma). 
514. El grano de la granada (34,232,8: 691. La forma potencial).

5I5. El grano de la corteza (34,232,9: 69I. El acabamiento).

516. El recién nacido en el vientre de la madre (34,232,II: 691. La forma).

517. El recién nacido en el vientre de la madre (34,232,I2: 691. La forma sensual).

518. La forma del oro y de la plata (34,232,I3: 692. La figura del hombre).

519. Los morabetinos de la caja (34,232,I4: 692. La forma de los metales).

52O. Los morabetinos ausentes (34,232,I5: 692. La materia).

52. El maestro que imagina la cámara (34,232,I8: 692. La forma).

522. Las partes de la nave (34,233,I6: 695. La causa final).

523. La nave que sirve al hombre (34,233,I7: 695. La causa final).

524. Las partes de la nave (34,233,I8: 695. El acabamiento).

525. El color de la manzana verde $(35,234,4: 697$. La cualidad).

526. El infante de corta edad (35,234,5: 697-698. La forma).

527. La forma de la nave $(35,234,6: 698$. La cualidad).

528. La sequedad del calor (35,234,7: 698. La cualidad).

529. El fuego caliente y el agua fría (35,234,8-9: 698. La cualidad).

530. La ligereza del fuego y del aire (35,234,I2: 698. La cualidad).

53. La madre que tiene un hijo feo (35,236,7-9: 705-706. La intelectualidad).

532. El hombre que no cree (35,236, IO: 7O6. La significación).

533. El hombre que sobrevive al veneno (35,236, II: 7o6. La significación).

534. El hombre que mira a la luna (35,236, I6: 7O7. La significación).

535. El hombre que tuerce el ojo para ver la luna (35,236,18: 7O7. La intelectualidad).

536. El espejo torcido (35,236,29: 708. La intelectualidad).

537. El hombre sabio (35,237,I3: 7 IO. El alma).

538. El hombre airado y triste (35,237,I4: 7IO. El alma).

539. El movimiento del sol (35,237,28: 7II. La vista).

540. El espejo sujeto $(36,238,6:$; 12 . La fe).

54I. La figura del oro y de la plata (36,238,9: 7I4. El alma).

542. El católico que cree la verdad (36,238,27: 7 I6. El alma).

543. El brillo del sol (36,239,8: 7I7. La razón).

544. El maniquí de madera (36,239,I3: 7 I8. La razón).

545. El plomo que cae (36,239,I4: 7 18 . La razón).

546. El turbamiento de los humores (36,239,I5: 718. La razón).

547. El color medio entre el blanco y el negro (36,239,2I: 718-719. La duda).

548. Los dos cuerpos en un lugar (36,239,29: 719. La razón).

549. La huella del animal (36,240,5: 720. La fe).

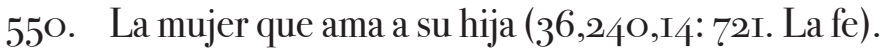

551. El barco vacío y aparejado (36,240,I6: 72I. La fe).

552. El fuego hace humo (36,240,19: 72I-722. La fe).

553. El hombre justo, viejo y feo (36,240,24: 722. La fe).

554. El hombre que se mira en dos espejos (36,240,28: 722-723. La fe).

555. El verdadero espejo (36,240,29: 723. La fe).

556. El espejo torcido (36,240,29: 723 . La fe).

557. El espejo claro y reluciente (36,24I,9: 724. La potencia racional).

558. El hombre enrevesado (36,24I,I4: 724. La potencia racional).

559. El fuego en la nieve (36,24I,I5: 724. La potencia racional).

56o. El hombre sediento por la fiebre (36,24I,I6: 724. El intelecto). 
56I. El marido que amaba su mujer (36,24I,2O-2I: 725. El intelecto).

562 . Los padres del judío $(36,242,4: 726$. La fe).

563. El hombre colérico $\left(36,24^{2}, 5: 726\right.$. La fe).

564. El hombre que se vuelve colérico (36,242,8: 727. La fe).

565. El hijo del sarraceno (36,242,IO: 727. La fe).

566. El cristiano renegado (36,242,15: 727. La fe).

567. El hijo del hereje (36,242,I6: 727-728. La fe).

568. El plomo que cae (36,242,20-2r: 728 . La fe).

569. El hombre católico (36,242,22: 728. La fe).

57O. El hombre atado (36,242,27: 729. La fe).

57 I. La existencia del aire y del agua (36,242,28: 729. La fe).

572. La generación de los animales (36,242,29: 729. La fe).

573. El hombre formado $(36,242,3 \mathrm{O}: 729$. La fe).

574. Las cuatro complexiones (36,243,5: 730. La sensualidad).

575. La materia y la forma del cuerpo (36,243,6: 730. La sensualidad).

576. La ponderosidad del plomo (36,243,8: 730 . El alma).

577. Los hombres a quienes amargan los dulces (36,243,I2: 730. La sensualidad).

578. El movimiento del plomo (36,243,I4: 73I. La razón).

579. La orina del enfermo (36,243,I7: 731. La razón).

58o. El hombre atormentado (36,243,23: 732. La razón).

58I. Los hombres que yacen con hombres y mujeres (36,243,27: 732. El término medio).

582. El ciego en la habitación (36,244,20: 735. La razón y la fe).

583. La lima de acero $(36,244,24: 735$. La fe).

$5^{84}$. La materia y la forma del fuego $(36,244,30: 736$. El alma).

585. El hombre que se mira la cara en el espejo (36,246,r9: 742. La Trinidad).

586. El entendimiento del hombre (36,246,20: 742. La Trinidad).

587. El pensamiento humano (36,246,21: 742. La Trinidad).

588. El alma del hombre (36,246,22-24: 742-743. La Trinidad).

589. El hombre y la manzana podrida (36,246,26: 743 . La Trinidad).

590. El hombre que se tapa los ojos (36,246,28-30: 743-744. La Trinidad).

591. La forma de la nave $\left(36,247,25^{-26}: 747\right.$. El Creador).

592. La forma del triángulo (36,247,28-30: 747. El Creador).

593. La corrupción del cuerpo (36,248,II: 749. El mundo).

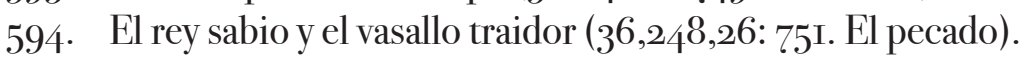

595. El hombre bello y rico (36,249,6: $75^{2}$. La gloria).

596. El aire que recibe fuego y agua (36,249,25-27: 755 . La gloria).

597. El cambiador que trata el oro $\left(36,250,2 \mathrm{I}: 75^{8}\right.$. La conciencia).

598. Los ojos de los hombres (36,25I,28: 763 . La Encarnación).

599. El hombre que busca algo (36,253,16: 769 . La intelectualidad).

6oo. La materia elemental (36,253,19-20: 769. La comunión).

6oI. La vista engaña el entendimiento (36,253,24: $77 \mathrm{O}$. El entendimiento).

602. El enfermo que encuentra amargos los dulces (36,253,25: 77O. La potencia divina).

6o3. El cambio de forma del demonio (36,253,26: 770. La comunión).

604. La materia, la forma y la conjunción (37,255,II: 776. La Trinidad).

605. La forma de la nave (37,256,6: 778. La sabiduría).

6o6. Los señores que pagan a juglares (37,256,9: 779. La virtud divina).

6o7. La belleza y los buenos olores (37,256,IO: 779 . El Creador). 
6o8. El falso vasallo (37,259,9: 787. La razón).

6o9. La joven casada con un viejo (37,260,25: 792. La lujuria).

6Io. La visión de los ojos (37,26I,I4: 794. La memoria).

6II. La visión de los ojos (37,261,I8: 795. El alma).

6r2. Las dos manos de los hombres (37,26r,29: 796. La ayuda).

6r3. La materia y la forma (37,262,I5: 797. La falsedad).

6I4. La forma de los vegetales (37,263,I: 799. La codicia).

6I5. El lujurioso que desea a la mujer del prójimo (37,263,3: 799. Los mandamientos).

6r6. Los artesanos que ofrecen a sus hijas (37,263,26-27: 8oo. La envidia).

6I7. El carpintero que da forma a la madera (38,265,II-I2: 806. La obra).

6I8. Los árboles frutales (38,265,20-2I: 806-807. La obra).

6r9. El espejo que refleja la forma (38,266,2: 8og. La predestinación).

620. El hombre que carga un pesado fajo (38,266,3: 8og. La predestinación).

62I. El maestro que hace la nave (38,266,I9-20: 8II. El conocimiento de Dios).

622. El hombre que honora a su señor (38,266,23: 8I2. La predestinación).

623. La bestia que carga un fajo (38,266,28: 812. La predestinación).

624. La visión de los ojos (38,266,29: 8I2-8I3. La predestinación).

625. La forma de los animales y de los vegetales (38,266,30: 8I3. La predestinación).

626. El sabor de la manzana y de la pera (38,266,30: 8I3. La predestinación).

627. La potencia y el acto en el tiempo (38,267,I: 8І3. El libre albedrío).

628. El labrador que siembra trigo (38,267,I5: 8I4. La predestinación).

629. El hombre que se mira en dos espejos (38,267,23: 8I5. La predestinación).

63o. El reflejo de la cara en el espejo (38,267,24: 8I5-8I6. La predestinación).

63I. El grano que será espiga (38,267,29: 8I6. La predestinación).

632. El labrador que conoce la espiga (38,267,30: 8ı6. La predestinación).

633. El hombre que se acerca a un gran fuego (39,273,I5: 836. El amor de Dios).

634. La habitación oscura (39,273,18: 836. El amor de Dios).

635. La piedra del trabuquete (39,273,27: 837. El amor de Dios).

636. El aparejamiento del gran barco (39,273,30: 838. El amor de Dios).

637. La brasa del fuego $(39,274,5: 838$. El alma).

638. El resplandor del sol $(39,274,7: 838$. La Trinidad).

639. El hombre que se acerca al fuego (39,274,8: 838. El alma).

640. La materia, la forma y la conjunción (39,274,Ir: 839. El amor de Dios).

64I. La caramida que mueve la aguja (39,274,I2: 839. El amor de Dios).

642. La mujer bella que se mira en el espejo (39,275,6: 842. Los ángeles).

643. Los ojos que reciben la luz del sol (39,275,8: 842. Los ángeles).

644. El sol que ilumina los ojos (39,275,II-I2: 842. Los ángeles).

645. La corrupción del cuerpo humano (39,275,23: 844. Los ángeles).

646. El hombre que escala (39,276,2: 845. Los ángeles).

647. La corrupción del cuerpo humano (39,276,3: 845. Los ángeles).

648. Las cualidades de los cuatro elementos (39,276,4: 845. Los ángeles).

649. Los elementos que componen los cuerpos (39,276,5: 845. Los ángeles).

650. Los cuerpos elementales (39,276,6: 846. Los ángeles).

65I. El hombre enamorado (39,276,9: 846. Los ángeles).

652. El amigo que ama la semejanza $(39,276,9: 846$. Los ángeles).

653. La forma y la materia (39,277,3: 849. El amor a Dios).

654. El barco lleno de agua (39,277,2 I: 85I. El amor a Dios). 
655. La jarra llena de agua (39,277,26: 852 . El amor a Dios).

656. La plata y el plomo (39,277,28: 852. El amor a Dios).

657. El pintor que ornamenta las figuras (39,278,I4: 854. La naturaleza de Dios).

658. El trapo extendido (39,278,21: 855. La humanidad de Dios).

659. El cirio que ilumina la habitación (39,278,24: 855. La humanidad de Dios).

66o. La gota de agua en la mar $(39,278,25: 855$. La humanidad de Dios).

66I. El hombre que tenía miedo a morir (39,278,30: 856. El amor de Dios).

662. La falsedad de dos proposiciones verdaderas (39,279,I7-I8: 858. La falsa intención).

663. Las guías del marinero (39,280,3: 860. El entendimiento).

664. El príncipe malvado (39,280,I2: 86r. El entendimiento).

665. El infante de corta edad (39,280,26: 862. El amor a Dios).

666. La ponderosidad de la tierra (39,280,30: 863. El amor a Dios).

667. Los hombres vanagloriosos (39,28I,3: 863. El amor a Dios).

668. El hombre que encendía un cirio (39,28I,I4: 864. La humildad).

669. La ponderosidad del plomo (39,28I,I5: 864-865. La humildad).

670. El aire que recibe las cualidades de fuego y agua (39,28I,2I: 865. La misericordia de Dios).

67I. El amor del que pide caridad (39,281,26: 866. El amor a Dios).

672. El ignorante que quiere ser sabio (39,28I,30: 866. La paciencia).

673. La necesidad del arte en el oficio (39,282,r: 866. El amor a Dios).

674. El arte de la carpintería (39,282,3: 867. Las cualidades de Dios).

675. El hombre colérico que se convirtió en flemático (39,282,IO: 867-868. El alma).

676. Las dos proposiciones (39,282,II: 868. La imaginación).

677. El molino que va hacia atrás (39,282,I8: 869. El acto y la potencia).

678. Las formas del oro y de la plata $(39,282,20: 869$. El alma).

679. El maestro que sabe hacer bellas figuras (39,282,20: 869. El acto y la potencia).

68o. El ciego que puede hacer bellas figuras (39,282,20: 869 . El amor a Dios).

68I. La nave que se cargaba y se vaciaba (39,282,2r: 869 . El alma).

682. El hombre que amaba más el pan que la vida (39,282,22: 869. La gula).

683. El buey que come hierba (39,282,28: 870. La contemplación).

684. La gota de agua (39,283,I4: 872. La obra de Dios).

685. El hombre que mide la madera (39,284,3: 875. La renuncia al mundo).

686. El movimiento de los cuerpos (39,284,II: 876. El alma).

687. Las dos proposiciones concordantes (39,284,I4: 876. Los deleites del mundo).

688. Los herederos interesados (39,284,28: 877. El deshonor a Dios).

689. El trapo bello $(39,284,26: 878$. El alma).

690. El palacio del pecador $(39,284,27$ : 878. El deshonor a Dios).

69ı. El hombre que se mira la cara en el espejo (39,285,3: 879. La Virgen).

692. El agua del mar y la del pozo (39,285,6: 879. La Virgen).

693. El dinero de oro y los de cobre $(39,285,3$ : 88o. La Virgen).

694. La figura reflejada en el espejo (39,288,3: 89o. La fe).

695. El anillo de oro con rubís (39,288,3: 89ı. La voluntad).

696. La forma que se ajusta a la materia (39,288,I7: 892. La voluntad).

697. El cuerpo del hombre (39,288,r9: 893. La fe).

698. El mulo hijo del caballo y de la burra $(39,289,5-6$ : 895 . El amor).

699. El infante diminuto (39,289,8: 896. El alma).

7oo. El buen vino (39,289,9: 896. El alma).

7OI. El agua de la mar y la del pozo (39,289,I2: 896. El amor). 
7O2. El hombre sediento (39,289,I4: 89. El amor).

703. La materia elemental (39,289,29: 899. La voluntad).

7O4. La mano que ayuda a la otra (39,290,9: 900. El cuerpo y el alma).

7O5. El fuego que va hacia arriba (39,290,I6: 9OI. El pecado).

7o6. El enfermo que encuentra amarga la miel (39,290,I8: 9OI. El pecado).

7O7. El hombre sediento (39,290,I9: 9O2. El cuerpo y el alma).

708. El cuerpo enfermo (39,290,20: 9O2. El cuerpo y el alma).

709. El infante que aprieta un pájaro hasta matarlo (39,290,23: 902. El amor a Dios).

7IO. El resplandor del sol (39,29I,2: 9O3. La sabiduría).

7II. El aire que recibe calor del fuego (39,29I,2: 903. La sabiduría).

712. El hombre que se acerca al fuego (39,29I,3: 903. La potencia vegetativa).

7I3. El agua se colorea por el continente (39,29I,3: 903-904. La sabiduría).

7I4. El movimiento natural del agua $(39,29 I, 5: 904$. El entendimiento).

7I5. La ausencia de luz (39,29I,5: 9O4. El entendimiento).

7i6. La forma y la materia del cuerpo (39,291,7: 904. El entendimiento).

717. Los ojos cerrados (39,29I,9: 9O4. El entendimiento).

7I8. La piedra que cae hacia abajo (39,291,9: 905. El entendimiento).

719. La aguja que naturalmente apunta al norte (39,29I,I8: 906. La sensatez).

720. El hombre que mueve el bastón (39,29I,24: 9O7. La sabiduría).

72I. El agua que erosiona la piedra (39,291,25: 907. La sabiduría).

722. La forma de la nave (39,291,26: 907. La sabiduría).

723. El monaguillo que se sabe antes la lección (39,291,27: 907. La sabiduría).

724. El cuerpo del hombre enrevesado (39,292,I2: 909. El deshonor).

725. El loco con un cuchillo (39,292,I2: 909. El deshonor).

726. La mujer pública que se maquilla (39,292,23: 9II. La honra).

727. El rey y el vasallo (39,292,26: 9II-9I2. La honra).

728. Los excrementos del albergue (39,292,29: 912. La honra).

729. El príncipe que ama la fama (39,292,30: 9I2. La honra).

730. El instrumento artificial (39,293,8-9: 913-9I4. La ordenación).

73I. El pastor que lleva el lobo a las ovejas (39,293,I4: 9I4. La potencia vegetativa).

732. El maestro que desea hacer una nave (39,293,I5: 9I4. La potencia vegetativa).

733. La mano que ayuda a la otra mano (39,293,I6: 9I4-9I5. La potencia sensitiva).

734. El cuerpo que mueve a otro (39,293,I8: 9I5. La ordenación).

735. El cuerpo que enferma (39,293,I9: 9I5. La potencia imaginativa).

736. El cuerpo que ha de reposar $(39,293,2 \mathrm{I}: 9 \mathrm{9} 5-9 \mathrm{I} 6$. La potencia imaginativa).

737. El infiel que no cree en la Resurrección (39,293,23: 9I6. La potencia sensitiva).

738. El cuerpo que enferma (39,293,27: 916-9I7. La potencia racional).

739. El tiempo que se origina en el firmamento (39,293,28: 9I7. La intelectualidad).

740. El agua no va por encima de la fuente (39,294,5-6: 918. El artificio).

74I. El cuerpo es largo y ancho (39,294,7: 9I8. El amor intelectual).

742. El fuego va hacia arriba $(39,294,8: 918$. La intelectualidad).

743. La piedra que apaga el fuego (39,294,9: 918. La intelectualidad).

744. El espejo torcido (39,294,I4: 9I9. El amor intelectual).

745. El cuerpo que se corrompe (39,294,22: 920 . El alma).

746. La conjunción de materia y de forma $(39,295,2: 922$. La santidad).

747. Los cuatro elementos (39,295,4: 922. La santidad).

748. Los cuatro elementos (39,295,I9: 924. La santidad). 
749. El hombre que va de un lugar a otro $(39,295,25: 925$. La paciencia).

750. El cielo es más bello que la tierra (39,296,6: 926 . El cuerpo y el alma).

75. El oro vale más que el hierro (39,296,8: 927. La oración).

752. El oro vale más que la plata $(39,296,9: 927$. La oración).

753. El gordo que quería ser delgado (39,296,II: 927. La oración).

754. El enfermo que se agita en la cama (39,296,18: 928. La oración).

755. El barco vacío $(39,296,20: 929$. La oración).

756. La pasión del prisionero (39,297,8: 93I. El alma).

757. El vasallo que se imagina a su señor (39,297,II: 93I. La libertad).

758. El mal vasallo (39,297,I2: 93I. La libertad).

759. La materia y la forma que hacen el cuerpo (39,298,r: 934. La ordenación).

760. Los cuatro elementos (39,298,8-9: 934. La ordenación).

76r. El bastón batido en el aire (39,298,27: 937-938. La ordenación).

762. El trigo quemado por la lluvia $(39,298,27: 938$. La ordenación).

763. El médico que cura al colérico (39,298,27: 938. La ordenación).

764. El barco lleno de licor (39,299,28: 942. El alma).

765. Los peces nacen en el mar (39,300,3: 943. La primera intención).

766. La carta del prestamista (39,300,9: 943. La intención).

767. La simiente bajo tierra (39,300,I4: 944. La potencia racional).

768. Las simientes de los vegetales (39,300,I5: 944. La intelectualidad).

769. El espejo torcido (39,300,21: 945. La potencia racional).

770. Las ramas de la higuera (39,300,24: 945. La primera intención).

77. El instrumento del juglar (39,300,26-27: 946. La primera intención).

772. La figura reflejada en el espejo (39,302,2: 950. El alma).

773. El médico que cura el cuerpo (39,302,5: 95I. El alma).

774. El esfuerzo por cargar la ballesta (39,302,9: 95I. El alma).

775. El humo que significa el fuego (39,302,II: 952. La finalidad).

776. El agua tibia (39,303,9: 955-956. La vía media).

777. El grano enterrado (39,303,I4: 956. La intelectualidad).

778. El enfermo de hidropesía (39,303,20: 957. El alma).

779. El marinero sabio (39,304,3: 959. La primera intención).

780. El pájaro que se transforma cuando vuela (39,304,7: 959-960. La segunda intención).

78I. El infante que aprieta al pájaro hasta matarlo (39,304,9: 960. La primera intención).

782. El príncipe que origina guerras (39,304,9: 960. La primera intención).

783. El pastor que muere por sus ovejas (39,304,II: 960. La primera intención).

784. La figura del hombre en el agua (39,304,I9: 96r. La primera intención).

785. El caballero malvado (39,304,23: 962. La causa final).

786. El clavo que deshierra al caballo (39,304,23: 962. La causa final).

787. El hombre sin nariz (39,304,26: 962. La primera intención).

788. El rebaño que quiere acabar con el pastor (39,304,27: 962. La primera intención).

789. El fuego es fuente de calor $(39,305,2: 963$. El amor intelectual).

790. La cabeza cumplimiento de todos los miembros (39,305,3: 963. La potencia racional).

79I. El infante que ama a su nodriza $(39,305,7: 964$. El amor).

792. El valor del esclavo (39,305,26: 966 . El falso amor).

793. El espejo que refleja (39,306,3: 967 . El entendimiento).

794. La mezcla de colores (39,306,8: 968 . El amor).

795. El hueso se hace dentro de la carne $(39,306,25: 970$. El amor). 
796. El movimiento sigue el tiempo (39,307,24: 974. El amor y el desamor).

797. El cuerpo elementado (39,307,26: 974. El amor).

798. El hombre colérico $(39,308,5: 976$. El amor).

799. El hombre que gira la tabla $\left(39,308,20: 977^{-9} 97^{8}\right.$. La potencia racional).

8oo. El trapo blanco y el negro (39,308,30: 979. El amor).

8OI. La forma natural y la artificial (39,3IO,3: 984. El amor).

802. La materia de los cuerpos (39,3IO,I2: 985. El amor).

803. La forma artificial de la plata (39,3І0,I5: 986. El alma).

804. El alcadafe de cera (39,3IO,I5: 986. El alma).

805. La figura del hombre de mármol (39,3IO,29: 988. Los pecadores).

8o6. La cara reflejada en el espejo (39,3II,2-3: 988. El paraíso).

807. El resplandor del sol (39,3II,6: 989. La gloria).

8o8. El hombre ciego (39,3II,9: 989. La gloria).

8o9. El hombre que no ve bien (39,3II,II: 990. La gloria).

8Io. El vino que se amolda al barco (39,3II,I2: 990. El alma).

8II. El hombre que debía escoger entre dos caballos (39,3II,I8: 99I. El paraíso).

8I2. La naturaleza del fuego (39,3І2,IO: 994. El amor).

8I3. La nave en la mar (39,3І2,I2: 994. El amor).

8I4. Los cuatro elementos (39,312,26: 996. El alma).

8I5. El hombre vil (39,3I2,29: 996. El amor).

8i6. La forma de la datilera (39,313,8: 997. El cuerpo).

8I7. La datilera cortada (39,3I3,9: 997-998. El alma).

8ı8. El aire natural (39,3г3,I9: 999. El alma).

8ı9. El infante que nace (39,3І3,23: 999. El soñar).

820. La corrupción del entendimiento (39,3I3,26: IOoO. El soñar).

82I. El peso de la balanza (39,3I3,27: IOOO. El soñar).

822. El hombre colérico (39,313,28: IOOO. La oración).

823. Las figuras del espejo (39,313,30: Iooo. La profecía).

824. El espejo torcido (4O,3I5,I3: IOO6. La oración).

825. La longitud y la amplitud (4O,3I5,26-27: IOO7-8. La oración).

826. Los graneros llenos de trigo (40,315,28: IOo8. La oración).

827. La figura en el espejo (40,3I5,22: IOI6. La contemplación).

828. El ciego y el espejo (4O,3I5,23: IOI6. La contemplación).

829. La manzana podrida (4O,3I5,24: IOI6. Los infieles).

830. El pobre albergado por un príncipe (40,3I8,I8: IOI9. Los infieles).

83I. La piedra lanzada al aire (40,318,25: IO2O. El alma).

832. La saeta que se para (40,319,7: IO22. El alma).

833. La figura en el espejo (40,3I9,26: IO25. La humildad).

834. El rey humilde (40,3I9,27: IO25. La infinitud).

835. Las cualidades del fuego y del agua (40,320,6: IO26. La vida).

836. La substancia del alma (40,320,I2: IO27. La vida).

837. El vino en la botella (4O,32O,I4: IO27-8. La Trinidad).

838. Los peces más sabrosos (4O,320,I6-7: IO28. La vida).

839. Las superficies del cuerpo (4O,32O,22: IO28. La vida).

840. La virtud de la caramida (4O,32O,23: IO29. El alma).

84I. El fuego en la nieve (40,320,26: IO29-3O. El alma).

842. El agua y la tierra en la nieve (40,320,27: IO3O. El alma). 
843. El hombre que hace un nudo en la correa (40,322,6: I035. El poder).

844. El espejo torcido (4O,322,I2: IO36. El poder).

845. La rueda que se mueve por el agua (40,322,I3: IO36-7. El poder).

846. El traidor que mata a su señor (4O,322,I4: IO37. El poder).

847. El hombre que lleva un quintal de tierra (40,323,7: IO4O. La sabiduría).

848. La belleza de las criaturas (4O,323, II: IO4I. La sabiduría).

849. El resplandor del sol (40,323,22: IO43. La sabiduría).

850. El hombre que se mira en el espejo (40,323,27: IO43-4. El alma).

85I. Las propiedades del fuego (40,324,IO-II: IO46. La esencia).

852. El rey sabio que hace justicia al traidor (4O,324,20: IO48. La sabiduría).

853. El entendimiento humano (40,325,I4: IO5I. El alma).

854. La naturaleza de la salamandra (40,325,25-26: IO53. Los elementos).

855. La blancura y la negrura (40,325,29: IO54. La composición).

856. La gota de agua en el mar (40,326,I7: IO57. La gloria).

857. El aire no tiene partes (40,326,I8: IO57. La gloria).

858. El camello y el caballo (40,326,26: Io58. La gloria).

859. El cuerpo necesita los ojos (40,327,26: Io63. Los ángeles).

860. El hombre no puede con el resplandor del sol (40,327,29: I064. La Encarnación).

86I. La forma de la nave (4O,328,II: IO66. La bondad).

862. Las propiedades del aire (4O,328,I2: Io66-7. La Encarnación).

863. El hombre que habla por semejanzas (40,328,2I: I068. Las potencias del alma).

864. La naturaleza del fuego (40,329,4: IO70. El bien).

865. El resplandor del sol (40,329,23: IO73-4. La Encarnación).

866. Los barcos más grandes (40,329,29: IO74. La rectitud).

867. El entendimiento y el viejo libro (40,330,6: Io76. La misericordia).

868. El tres contiene el uno y el dos (40,330,I6: IO77-8. La misericordia).

869. El mar y la fuente (40,330,I7: IO78. La misericordia).

870. El sol brilla más que la luna (40,330,22: Io78. La misericordia).

871. La corrupción de la forma (40,33I,I9: Io83. La verdad y la falsedad).

872. El espejo derecho (4O,33I,20: IO83. La verdad y la falsedad).

873. La hoja del árbol (40,33I,20: ro83. La verdad y la falsedad).

874. La materia del platero (40,33I,22: IO83. La verdad y la falsedad).

875. La capacidad de los barcos (40,33I,26: Io83. La verdad y la falsedad).

876. El que dice que el ser es el no ser (40,33I,27: Io83. La verdad y la falsedad).

877. El hombre que se acerca al fuego (40,333,23: Io92-3. La humildad).

878. El agua de la mar (40,333,28: IO93. La humildad).

879. La mujer que amaba su figura (40,334,I5: Io96. La paciencia).

880. La naturaleza caliente de la pimienta (40,334,20: I097. La paciencia).

88I. La habitación llena de la luz del sol (4O,334,20: IO97. La paciencia).

882. El espejo sensual (40,335,7: ro99. El entendimiento).

883. El cuerpo largo y ancho (4O,335,II: IIOO. La predestinación).

884. El cuerpo compuesto (4O,335,I3: IIOO. La predestinación).

885. El resplandor del sol (4O,335,2I: IIOI. La unidad).

886. El combatiente que merece un galardón (40,336,26: IIO 7. La virtud de Dios).

887. La semejanza de la luna al sol (40,336,30: пाо8. La virtud de Dios).

888. El accidente y la substancia (40,338,7: III3. La Encarnación).

889. El noble vasallo (40,338,24: III5. La Encarnación). 
89o. El espejo más claro (40,339,7: III9. La humildad).

89I. La vista corporal (4O,339,30: II2I. La contemplación).

892. La piedra que cae hacia abajo (40,340,I8: II23. El bien y el mal).

893. El agua se adapta al barco (40,340,22-23: II24. La falsa figura).

894. Los remos que mueven la galera (40,340,24: II24. El pecado).

895. La vira de la ballesta (40,340,24: II24. El pecado).

896. La razón del maestro (40,340,30: II25. El mal).

897. La corrupción de la enfermedad (4O,34I,8: II26. La voluntad de Dios).

898. El monaguillo loco 4O,34I,IO: II27. La voluntad de Dios).

899. El espejo torcido (4O,34I,I2: II27. La voluntad de Dios).

900. El hombre que cae (4O,34I,I2: II27. La voluntad de Dios).

9OI. El fuego calienta el agua (40,34I,I3: II27. La voluntad de Dios).

902. La piedra que se tira hacia arriba (4O,34I,I4: II27. La voluntad de Dios).

903. La piedra que se tira hacia arriba (40,34I,I5: II27-8. La voluntad de Dios).

904. El resplandor del sol (4O,34I,22: II28. La voluntad de Dios).

905. El cuchillo que labra (40,342,5: II3O-I. La voluntad de Dios).

9o6. El infante que se mira en el espejo (40,342,I5: II32. La voluntad de Dios).

907. La unión de materia y forma (40,342,I6: II32. La voluntad de Dios).

908. El orden del fondo del mar (4O,342,2I: II33. La voluntad de Dios).

909. El movimiento del fuego y del aire (40,342,22-23: II33. La voluntad de Dios).

9IO. El hambre del enfermo (4O,342,24: II33-4. La corrupción del cuerpo).

9II. La materia elemental (40,342,27: II34. La corrupción del cuerpo).

912. La forma del mar (40,343,6: II35. El paraíso).

9I3. El que cambia estaño por plata (40,343,I9: II37. El paraíso).

9I4. El hombre que sueña con oro (40,343,2I: II37-8. El paraíso).

9I5. El recuerdo del amante (40,343,24: II38. El paraíso).

9I6. La vista corporal (40,344,I2: II4I. Jesucristo).

9I7. El hombre que levanta la paja (4O,344,20: II42. El arrepentimiento).

918. El agua de la fuente (40,344,24: II 43. El alma).

9I9. El enfermo con fiebre (40,344,24: II 43. El alma).

920. La materia, la forma y la conjunción (40,345,26: II48. La gloria).

92I. El hombre embriagado (40,345,27: II48. La gloria).

922. El cuerpo que mueve otro (40,346,I2: II5I. El poder).

923. El agua que mueve la rueda (4O,346,I5: II5 I-2. El poder).

924. El hombre que hace libros (40,346,26: II54. La devoción).

925. Los ojos que miran al sol (40,348,9: пі6г. La continencia).

926. El hombre arrebatado (40,348,I2: II6I. La continencia).

927. La causa final del maestro (40,348,I4: II62. La continencia).

928. El hierro que forma el cuchillo (40,348,I5: II62. La continencia).

929. Los cuerpos mayores que mueven los menores (40,348,I6: II62. La continencia).

930. El hombre comedor y bebedor (40,348,20: II62. La continencia).

93. El hombre que bebe y come demasiado (40,348,23: Ir63. La continencia).

932. El viajero con poca vianda (40,348,26: II63. La continencia).

933. El hombre que aprovecha el sol (40,348,27: II63-4. La continencia).

934. La materia elemental (40,348,29: II64. La continencia).

935. La materia, la forma y la privación (40,349,2: II64. La consolación).

936. El hombre que duerme (40,349,6: II65. La consolación). 
937. El hombre que pierde alguna cosa (40,349,,IO: II65. La justicia).

938. El hombre que perdió un dinero y encontró mil (40,349,ІІІ: II65-6. La consolación).

939. El hombre que encontró y perdió unos morabetinos (40,349,I8: II67. La consolación).

940. Los hombres que saben más que otros (40,349,2r: II67-8. La consolación).

94I. Los barcos vacíos (40,349,22: Ir68. La consolación).

942. El loco que desea volar (40,349,23: II68. La consolación).

943. Los pobres que no tienen oro ni plata (40,349,23: II68. La consolación).

944. El vasallo que honra a su señor (40,349,27: II68-9. La consolación).

945. Los miembros del cuerpo (40,350,2: II69-70. La obediencia).

946. El cuerpo atormentado (40,350,3: II7\% La obediencia).

947. El príncipe recto (4O,350,6: II70. La obediencia).

948. El príncipe que hace un llamamiento (40,350,6: II70. La obediencia).

949. El rey que hace el bien y da justicia (4O,35O,I2: II I. El cuerpo y el alma).

950. El agua de la pipa (40,35I,II: пI76. La voluntad).

95I. La pipa de agua (4O,35, I2: II76. La confesión).

952. El sol que calienta (4O,35I,I3: II76-7. La confesión).

953. El hombre no puede volar (4O,35I,I4: II77. La confesión).

954. La figura inversa del hombre en el agua (4O,35I,I5: II77. La confesión).

955. La figura pintada del juglar (4O,35I,I5: II77. La confesión).

956. El carpintero y el herrero (40,35I,24: II78-9. La confesión).

957. El hombre que entiende las cosas (40,352,2: Ir8o. La oración).

958. El hombre que lee y entiende (4O,352,5: II80. La oración).

959. El hombre que quiere saltar $\left(40,35^{2}, \mathrm{I} 3:\right.$ II82. El entendimiento).

960. El resplandor del sol (4O,352,I4: II82. El entendimiento).

96r. El movimiento de los animales (40,352,I8: II82-3. El entendimiento).

962. El vasallo que no es envidioso (40,352,23: II83-4. La contrariedad).

963. El vino del tonel (40,352,28: in84. La oración).

964. El fuego que quema y calienta (40,353,26: II9O. La primera intención).

965. La forma de la espada (40,353,27: I190. La primera intención).

966. Las bellas y nobles doncellas de la montaña (4O,354,2-30: II9I-5. El cuerpo y el alma).

967. Las tres damas que van a un palacio (4O,355,2-30: II95-I2OO. La contemplación).

968. El ermitaño que contemplaba a Dios (4O,356,I-30: I2OO-4. La contemplación).

969. El maestro sabio que imagina la nave (40,357,I7: I2O7. La sabiduría).

970. La madre que considera bello a su hijo (4O,357,21: 12O7. La imaginación).

97. El durmiente que se despierta de repente (40,357,26: I208. La imaginación).

972. El ciego que no ve los colores (40,357,27: I208-9. La imaginación).

973. El pan y el vino (40,357,28: ı209. La imaginación).

974. Las tres virtudes del alma (40,358,7-30: I2IO-4. El alma).

975. El árbol bello y bueno (40,359,24: I218. Las bellas palabras).

976. El monaguillo que aprende del maestro (40,359,29: г219. Las bellas palabras).

977. El monaguillo que desea aprender (40,359,30: I2I9. Las bellas palabras).

978. Los frutos maduros y sazonados (40,360,3: г220. El alma).

979. El caballo regalado al que no quiere cabalgar (40,360,I8: І222. El pecado).

980. El oro y la plata (40,360,21: 1222-3. La oración).

981. El oro del hombre rico (40,360,22: I223. La oración).

982. Los ojos del hombre (4O,360,23: I223. La oración).

983. La flor que sigue al sol (40,36r,9: 1226. Las potencias del alma). 
984. El cuerpo que sufre pasiones y enfermedades (40,36I,24: I228. Las potencias del alma).

985. El barco vacío (40,362,6: ı230. La verdad).

986. Los dos hombres que lanzan a otro (40,362,I6: I232. La verdad).

987. El hombre que está en el medio (40,362,I6: I232. La verdad).

988. La figura torcida en el espejo torcido (40,363,I8: I238. La justicia divina).

989. El tratamiento de los ojos corporales (40,364,3: I24I. La verdad).

990. El sol mueve la vegetación (40,364,8: I242. La verdad).

99I. La luna que quita claridad al sol (4O,364,II: I242. La verdad).

992. La forma de la figura del hombre (40,364,I6: ı242. La verdad).

993. El mármol no da calor (40,364,I8: 1243-4. La verdad).

994. El calor del fuego (40,364,2I: 1244. La verdad).

995. La nube ante el sol (40,364,23: 1244. La verdad).

996. Las siete virtudes y las tres causas (40,364,30: I246. La verdad).

997. Las nubes que embargan al sol (40,365,2: I246. Las potencias del alma).

998. Los tormentos del infierno (40,365,3: 1246. Las potencias del alma).

999. La obra de los ojos (40,365,6: 1247. Las potencias del alma).

IOoo. El hombre que escribe y lee (40,365,II: I247-8. Las potencias del alma).

IOOI. El agua que mueve la rueda del molino (40,365,I4: I248. Las potencias del alma).

IOO2. El platero que quiere crear formas (40,365,I5: I248. Las potencias del alma).

IOO3. El hombre sediento (40,365,I5: I248. Las potencias del alma).

IOO4. El barco lleno de agua (40,365,I6: ı248-9. Las potencias del alma).

IOO5. El barco roto (40,365,I7: I249. Las potencias del alma).

Ioo6. El hombre injurioso (40,365,I7: I249. Las potencias del alma).

IOO7. El hombre que golpea su cabeza en la pared (40,365,I7: I249. Las potencias del alma).

IOo8. El señor que ama a su vasallo (40,365,2I: I249. Las potencias del alma).

IO09. El maestro que alecciona al monaguillo (40,365,2I: I249. Las potencias del alma).

IOIO. El hombre que encuentra oro y plata (40,365,2r: I249. Las potencias del alma).

IOII. La nota del baile (40,365,27: I250. Las potencias del alma).

IOI2. El que no sabe afinar su instrumento (40,365,27: I250. Los pecadores).

IOI3. Los cuatro elementos se ayudan (40,365,29: I25O-I. Las potencias del alma).

IOI4. Los géneros y las especies (40,366,3: I25I-2. La bondad del libro).

IOI5. Las formas potenciales del platero (40,366,I2: I254. La demostración).

IOI6. El monaguillo y el maestro (40,366,I5: I254. El entendimiento).

IOI7. La forma de los animales (40,366,I6: I254-5. La demostración).

Ior8. Las viandas del cuerpo (40,366,г9: І255. Las razones).

Iог9. La figura del hombre (40,366, 2I: I255-6. La contemplación).

\subsection{Doctrina pueril}

(II.A.6 - Doctrina pueril [1274-6]. Total ejemplos: 25. Santanach 2005 [NEORL, 7]).

\section{Título (capítulo: pág. Tema).}

I. El fuego que calienta (5: 24. La gloria de los ángeles).

2. El dedo en el fuego (5: 26 . El fuego infernal).

3. Los pájaros que vuelan (II: 42. La gloria del paraíso).

4. El fuego en todo el mundo (45: II6. El gozo de María). 
5. La luz que ilumina los ojos (52: I32. La gracia de Dios).

6. El hombre sin ojos (54: I4O. La falta de caridad).

7. El hombre que no apreciaba (54: I4O. El saber amar a Dios).

8. Los gusanos de la cara (62: I62. Los compañeros de los avaros).

9. $\quad$ El torrente de agua (72: 187. Los gentiles).

IO. Las burbujas de agua (77: 2OI. Los elementos simples).

II. El mar hirviente (99: 278. El miedo al infierno).

I2. La olla de habas (99: 278. El dolor de los condenados).

I3. El mar hirviente (99: 278. El número de los condenados).

I4. El torrente de agua (99: 278. El hacinamiento en el infierno).

I5. Los troncos y las brasas (99: 278. El hacinamiento en el infierno).

I6. El horno (99: 278. El fuego del infierno).

I7. El pozo lleno de hierro fundido (99: 279. El fuego del infierno).

I8. La madera dentro del hielo (99: 279. La desnudez de los condenados).

I9. La corrupción de los animales muertos (99: 279. Los castigos del infierno).

20. Los carniceros que quitan la vida (99: 279-8o. Los tormentos de los demonios).

2I. Los perros cazadores (99: 280. Los tormentos de las almas).

22. El rey y el vaso de agua (99: 28o. El hambre y la sed del infierno).

23. Las gotas de agua, arena y estrellas (99: 280. La eternidad del infierno).

24. Los marineros en la tempestad (99: 28I. El evitar las penas infernales).

25. El tablero de ajedrez (IOO: 283. La gloria del paraíso).

\subsection{Libro contra Anticristo}

(II.A.8 - Llibre contra Anticrist [1274-6 (?)]. Total ejemplos: 2. Pons, Gayà, Schib I996, IO5-I60 [NEORL 3 , IO5-16o]).

Título (capítulo:pág. Tema).

I. La gonela y el capirote (I: I22. La unidad de Dios).

2. $\quad$ El siervo y el sometido (I: I38. La señoría de Dios).

2.4 Libro del gentily los tres sabios

(II.A.9 - Llibre del gentil e dels tres savis [1274-6 (?)]. Total ejemplos: 2. Bonner 1993 [NEORL, 2]).

Título (capítulo:pág. Tema).

I. El hombre acabado (3: II3. La Trinidad).

2. Los rayos del sol por el estercolero (3: I44. La perfección de Dios).

\subsection{Comienzos de medicina}

(II.A.IO - Liber principiorum medicinae; Començaments de medicina [1274-83]. Total ejemplos: 36 . Badia 2002, 35-I20 [NEORL, 5, 35-I20]).

Título (capítulo: pág. Tema). 
I. El martillo y las tenazas (I: 47. La medicina del cuerpo).

2. El imán que atrae al hierro (I: 49. La purga de la cólera).

3. El agua fría en verano (3: 7o. La contrariedad).

4. La cadena o el guarnimiento de hierro (5:82. Los principios de las ciencias).

5. Los siete días de la semana (7: 94. La fiebre cuartana).

6. Dios no es demostrable en este mundo (8: Ioo. El conocimiento de los elementos).

7. Los doce apóstoles y Jesucristo (IO: IO4. Los doce puntos).

8. Los puntos del cuerpo elemental (IO: IO5. La Encarnación).

9. La simplicidad del séptimo punto (IO: IO5. La unidad y la trinidad).

IO. La especie del punto simple (IO: IO5. La salud y la enfermedad).

II. El árbol cargado de frutos (IO: IO5. Las buenas obras).

I2. El pájaro que vuela (IO: IO5. La cruz).

I3. El leproso y el asno (IO: I05. Evitar el pecado).

I4. El firmamento gira alrededor de la tierra (IO: Io6. El séptimo punto).

I5. El séptimo punto (IO: Io6. El ayuno semanal).

I6. El cuarto grado de ABCD (Io: Io6. La Trinidad).

I7. La mezcla y la conjunción de la materia (Io: Io6. La primera materia).

I8. Los árboles que florecen (IO: IO7. La higiene).

I9. El hombre y el caballo atosigado (IO: IOZ. La duración de la vida).

2O. El maestro atosigado (IO: IO . La duración de la vida).

2I. El enfermo que desea beber y comer (IO: IO7. El apetito natural).

22. Los veinticuatro puntos (IO: IO8. Las veinticuatro horas del día).

23. El tercer grado y el segundo (IO: IO8. La esencia de Dios).

24. El fuego que hace hervir el agua (IO: Io8. La materia del cuerpo).

25. El agua que nutre los vegetales (IO: Io8. La sangre del cuerpo).

26. La vanagloria de los hombres (IO: IO9. La gracia de Dios).

27. La destrucción de la materia (IO: IO9. El poder de Dios).

28. La voluntad concuerda con el ser (IO: Iog. La Encarnación de Dios).

29. La rueda de papel o metal (Iо: IIо. Las horas que rigen ABCD).

30. El centro de la rueda (IO: IIO. Las horas de la noche).

3I. La tentación del demonio (IO: III. La operación de la potencia).

32. El veneno generado en animales y en plantas (IO: II2. Las hierbas laxantes).

33. La piedra con cualidades BD (IO: II2. Mortificar el verano A con BD).

34. El hombre que bebía agua (IO: II3. La delgadez).

35. La salamandra en el fuego (IO: II3. La temperancia de C por A).

36. El dominio del séptimo punto (IO: II3. La paciencia y la humildad).

\subsection{Blanquerna}

(II.A.I9 - Romanç d'Evast e Blaquerna [I276-83 - Montpelier]. Total ejemplos: I42. Carreras, Batllori, Carreras, Rubió i Balaguer, I957-I960, I, III-308 [OE, I, III-308]).

\section{Título (capítulo: pág. Tema).}

I. $\quad$ El ballestero, el parador y el ciervo (3: 28. El derecho divino y el humano).

2. Los viejos casados con jóvenes (I2: 57-8. Razones para la castidad).

3. $\quad$ El cambista rico y avaro (I3: 58-9. Vencer la avaricia). 
4. El trapero rico y orgulloso (I4: 6o. Vencer la soberbia).

5. El rico envidioso (I6: 62-3. Vencer la acidia).

6. El enfermo airado (iz: 63-4. Vencer la ira).

7. El religioso vanaglorioso (I8: 65-6. Vencer la vanagloria).

8. La prometida que murió de parto (I9: 69-70. El orden matrimonial).

9. La bella novia (25: 82. Los órdenes que olvidan el mundo).

Io. La mujer que dudaba de la fe (30: 88-90. La fe y el entendimiento).

II. La mujer en pecado mortal (3I: 9O-I. Vencer la desesperación).

I2. La mujer que quería la gloria de Dios (32: 92. La caridad).

I3. La monja por pobreza (32: 92. La caridad).

I4. La enferma que quería morir (33: 94. Vencer la ira).

I5. La pecadora encarcelada (33: 95. La justicia divina).

I6. La monja que lloraba (33: 95-6. La justicia divina).

I7. La mujer que no conocía su pecado (34: 96. La sabiduría).

I8. La mujer que hizo a su hijo abogado (34: 96-7. La sabiduría).

19. La mujer que no conocía la fe (34: 97. La sabiduría).

20. La mujer tentada por la vanagloria (35: 98. La fortaleza de la fe).

2I. La mujer tentada por el orgullo (35: 99. La fortaleza de la fe).

22. El mayordomo del rey rico (46: II7. El honor en la corte).

23. El escudero en palafrén (46: II7. El honor en la corte).

24. El mercader que lloraba (46: II7-8. El honor en la corte).

25. El hombre que llevaba ocas y gallinas (46: ir8. El honor y el conocimiento de Dios).

26. El caballero que veía el futuro (47: II9-2I. Los videntes).

27. El juglar de valor (48: I2I. El valor).

28. El caballero que iba a pie (48-- 22-5. El valor).

29. El pastor y el lobo (49: I25-9. La consolación).

30. El castillo del caballero (50: I29. La fortaleza y la caridad).

3I. El sabio filósofo (5O: I3O-I. La fortaleza y la caridad).

32. El lobo y las ovejas (52: $135^{-6}$. La penitencia).

33. Las dos monas (52: i36. La penitencia).

34. La zorra y el jabalí (52: 136. La penitencia).

35. El ermitaño que fue a la ciudad (53: I4I. La perseverancia).

36. El hijo del ciego (54: I42. La obediencia).

37. El médico y el clérigo (56: I 46. El ordenamiento).

38. El herido de muerte (56: 146 . El ordenamiento).

39. La zorra y el águila (56: I46-7. El ordenamiento).

40. El ruiseñor y el árbol florido (56: I47. El ordenamiento).

4I. El burgués en el monasterio (57: I48. La consolación).

42. La higuera, la datilera y el pino (57: I49. El orgullo).

43. El rico enfermo (57: I49. El perdón).

44. Fortaleza y Prudencia (6o: I59. La multiplicación de la gloria).

45. El que dudaba de la gracia de María (62: 162-3. La gracia de la Virgen).

46. Los hombres que querían una viña (63: ı66-7. La fuerza de la palabra de Dios).

47. El caballero que cantaba a una dama (64: I68-7I. María primera mujer).

48. El caballero y el rey sarraceno (64: I7 I-2. María madre de Dios).

49. El clérigo mallorquín en el sínodo (65: I73. El modelo de Miramar).

50. El pastor que pecaba con una mujer (66: I76-7. La oración a María). 
5I. El pastor que soñaba que lo colgaban (66: I78. La necesidad de perdón).

52. El clérigo que daba ejemplos a los pastores (66: I79. La palabra de Dios).

53. El burgués rico (69: 185-6. La pobreza).

54. La mujer del marido lujurioso (70: 187. La victoria al pecado).

55. El que acusaba de ladrón a otro (70: I87-8. La victoria al pecado).

56. Los hombres que se acuchillaban (70: I88. La convicción de no hacer el mal).

57. El príncipe que desheredó a la Iglesia (70: I88-9. La convicción de no hacer el mal).

58. El canónigo que veía matar los corderos añales (7i: r9o. El trato de los judíos a Jesús).

59. La mujer del cautivo (7І: I9O-I. El arrepentimiento).

6o. El canónigo y las prostitutas (7І: 19I. El arrepentimiento).

6I. El rico burgués sin hijos (7I: I9I. El arrepentimiento).

62. Las mujeres maquilladas en la Iglesia (7I: I9I-2. El arrepentimiento).

63. El archidiácono que iba a su castillo (72: 193. La aflicción).

64. Los religiosos que litigaban (72: 193. La aflicción).

65. El hombre que daba a un pobre (72: 193-4. La aflicción).

66. El rico que alimentaba a los pobres (72: 194. La aflicción).

67. El condenado a muerte (73: 194-5. La misericordia).

68. El campesino robado por el vecino (73: 195-6. La misericordia).

69. El campesino que perdió un buey (73: I96-7. La misericordia).

7O. El hombre con una serpiente en el vientre (74: 197-8. La limpieza).

7I. La mujer bien vestida y maquillada (74: 198-9. La limpieza).

72. Los judíos conversos (75: 199-200. La paz).

73. El castillo de los dos caballeros (75: 200. La paz).

74. El burgués rico y lujurioso (75: 200-I. La paz).

75. El trapero que asesinó a un mercader (75: 2OI. La paz).

76. La taberna de tahúres, goliardos y rufianes (76: 202. La persecución).

77. Los traperos, los tahúres y los rufianes (76: 203. La persecución).

78. El caballero que iba a ser enterrado (76: 203-4. La persecución).

79. El archidiácono que recibía honores (76: 204-5. La persecución).

8o. El canónigo que enloqueció (76: 205. La persecución).

8I. El ladrón que iba a ser colgado (76: 205-6. La persecución).

82. Los hermanos apostólicos (76: 206. La persecución).

83. El cardenal vanaglorioso (79: 2I3-4. El buen ordenamiento).

84. Ramón el loco (79: 2I4. El buen ordenamiento).

85. La letra del sultán de Babilonia (80: 2I7. La gloria de Dios).

86. Los asesinos que mataron a dos cristianos (80: 2I7-8. La gloria de Dios).

87. El escribano que hacía un libro (80: 218. La gloria de Dios).

88. El hombre que amaba a la más bella (80: 219. La gloria de Dios).

89. El cardenal que vigilaba al príncipe y al obispo (80: 220-I. La gloria de Dios).

90. El caballero presbítero y los sarracenos (80: 22I-2. La gloria de Dios).

9I. Los tártaros conversos (80: 222. La gloria de Dios).

92. Los judíos y los sarracenos conversos (80: 222. La gloria de Dios).

93. Los dos reyes que combatían (8I: 223-4. La paz).

94. El matrimonio arreglado por el hijo (8г: 223. La paz).

95. Los dos traperos que discutían (8I: 224. La paz).

96. Los dos que se insultaban (8I: 224-5. La paz).

97. Los reyes que querían la tierra del arzobispo (8I: 225. La paz). 
98. El viejo casado con una joven (8I: 225. La paz).

99. El noble que deseaba el consejo del cardenal (8г: 226. La paz).

IOO. El procurador de los dos príncipes (8г: 226-7. La paz).

IoI. La madre de un clérigo y de un lego (82: 227-30. La alabanza).

IO2. El hombre santo (82: 229. La alabanza).

IO3. El obispo devoto y mártir (82: 229. La alabanza).

IO4. El filósofo converso (82: 229. La alabanza).

IO5. El caballero que loaba a Dios (82: 229-30. La alabanza).

Io6. El mercader que enviudó (83: 232-3. La bendición debida).

IO7. El canónigo que quería ser obispo (83: 232. La bendición debida).

I08. El hombre que asesinó a otro (83: 232. La bendición debida).

Io9. El hombre que loaba a Dios (83: 232. La bendición debida).

IIO. Los hombres que jugaban a dados (83: 233. La bendición debida).

III. El religioso que oía misa (83: 233-4. La bendición debida).

II2. El ribaldo que recibió un palafrén (83: 234. La bendición debida).

II3. La cuestión entre tres sabios (84: 237. La adoración a Dios).

II4. La letra del rey moro sobre la fe (84: 238. La adoración a Dios).

II5. La tierra de los gentiles (84: 238-9. La adoración a Dios).

II6. El cardenal y las joyas (84: 239-40. La adoración a Dios).

II7. El rey que se esparcía (85: 240. La gloria de Dios).

II8. Los hijos del rey que aprendían de armas (86: 244-5. El agradecimiento a Dios).

II9. El hijo del conde que iba a Boloña (86: 245. El agradecimiento a Dios).

I20. Jofa y el anegado (87: 246. La omnipotencia de Dios).

I2I. Los predicadores expulsados (87: 247. La omnipotencia de Dios).

I22. El rey sarraceno que prohibió los predicadores (87: 247-8. La omnipotencia de Dios).

I23. Los portadores de nuevas (88: 25I. Los buenos ejemplos).

I24. El falso portador de nuevas (88: 25 $5^{\mathrm{I}-2}$. Los buenos ejemplos).

I25. El obispo que hacía inquisición (89: 253. Los buenos ejemplos).

I26. El pleito del obispo y del canónigo (90: 254. Los buenos ejemplos).

I27. El procurador del arzobispo (90: 254-5. Los buenos ejemplos).

I28. El capítulo general de los predicadores (90: 255. Los buenos ejemplos).

I29. El cristiano que tenía deudas con un judío (9г: 256. Los buenos ejemplos).

I30. La sentencia del entendimiento (91: 257-8. Los buenos ejemplos).

I3I. El archidiácono que hablaba del paraíso (92: 258. Los buenos ejemplos).

I32. El rey desheredado (92: 258-9. Los buenos ejemplos).

I33. El obispo acusado por su capítulo (92: 259. Los buenos ejemplos).

I34. El hombre que conspiraba (92: 259-6o. Los buenos ejemplos).

I35. La muerte del hijo del burgués (92: 260. Los buenos ejemplos).

I36. El hombre que gritaba que valía más (92: 260. Los buenos ejemplos).

I37. Qué vale más Diríauno o Pocomeaprecio (92: 26o-I. Los buenos ejemplos).

I38. El hombre que lloraba en un sermón (93: 26I-2. La necesidad de sermones).

I39. Los mensajeros del cardenal (94: 263-4. La predicación).

I40. Los hermanos que no podían viajar (95: 265-6. La predicación).

I4I. Los mensajeros del rey de la India (95: 266 . La concordia).

I42. Los ermitaños de Roma (97: 269-7O. El oficio). 
2.7 Libro de los ángeles

(II.A.20 - Llibre dels àngels [1276-83 (?)]. Total ejemplos: I7. Tous, Ginard I950, 307-375 [ORL, 2I, $3 \mathrm{O}-375])$.

Título (pág. Tema).

I. $\quad$ El hombre que ignora (325. El amor de los ángeles).

2. El carpintero que construye una nave (327. La materia de los ángeles).

3. $\quad$ El hombre justo (327. La materia de los ángeles).

4. La materia y la forma de los hombres (330. La substancia de los ángeles).

5. $\quad$ El calor del fuego (334. La bondad de los ángeles).

6. $\quad$ El sol que ilumina (337. El amor de los ángeles).

7. $\quad$ El calor del fuego (338. La perfección de los ángeles).

8. $\quad$ El hombre con pies y manos (347. El poder de los ángeles).

9. El pensamiento de los hombres (354. La locución de los ángeles).

IO. Las potencias de los hombres (355. La locución de los ángeles).

II. El conocimiento de los hombres (356. La locución de los ángeles).

I2. Los dos hombres en el espejo (358. Los ángeles y los demonios).

I3. Los malos hombres que hablan (358. La locución de los demonios).

I4. El maestro que hace una nave (362. La locución de los ángeles).

I5. La piedra que cae (372. La pena de los demonios).

I6. El hierro en la fragua (374. La pena de los demonios).

17. El debate de los elementos (374. La pena de los demonios).

\subsection{Libro de maravillas}

(II.B.I5 - Llibre de meravelles [1287-9 - París]. Total ejemplos: 520. Bonner 1998, 2, 7-393 [OS, 2 , 7-393]).

Título (capítulo, edición, pág. Tema).

\section{Libro primero}

I. $\quad$ El rey de justicia (I: 22. La finalidad de todas las cosas).

2. El círculo de la divinidad (I: 23. El alcance del mundo).

3. La serpiente que atemoriza (I: 23-24. El miedo a la muerte).

4. La piedra preciosa (2: 24-25. El alcance del conocimiento).

5. El rey sabio y la dama (2: 25. El conocimiento de Dios).

6. El rey, la reina y la doncella (2: 25. El pueblo de Dios).

7. $\quad$ El mercader satisfecho por Dios (2: 26-27. La finalidad de los hombres).

8. El caballero y el ermitaño (2: 27. El oficio de los hombres).

9. El caballero y la dama casta (2: 27-28. La realidad de los conceptos).

IO. El hijo del filósofo (2: 28. La obra de Dios y de los hombres).

II. El rey bien acostumbrado (3: 28-29. La finalidad del mundo).

I2. El rey loco y el rey sabio (3: 29. La finalidad del mundo).

I3. El caballero perdido en el bosque (3: 30-3I. La finalidad de los hombres).

I4. El predicador de la Trinidad (4: 3I. Los dogmas).

I5. La ciudad con malas costumbres (4: $3^{\mathrm{I}} 3^{2}$. El reino de Dios). 
I6. El mercader enfermo (4: 32-33. La creencia y el entendimiento).

I7. El cristiano, el filósofo y el judío (4: 33-34. La Trinidad).

I8. El sabio y el filósofo (4: 36-37. La Trinidad).

I9. El rey y los dos sabios (4: 37. El conocimiento de Dios y los hombres).

20. El salto del escudero (4: 37. La potencia de Dios y los hombres).

2I. El sabio y el loco (5: 38. La perfección de la creación y de Dios).

22. El hombre que tenía frío $(5: 39$. El comportamiento del fuego).

23. La noticia falsa (6: 39. La omnipotencia divina).

24. El ermitaño en la ciudad (6: 39-40. La creación de los hombres).

25. El esclavo del clérigo (6: 40. La voluntad de los hombres y de Dios).

26. El santo predicador (6:40-4I. Los artículos de la fe).

27. El abad depuesto (6: 4I. La primera intención).

28. Los reyes que no tenían hijos (6: 4I-42. El oficio de los reyes).

29. El obispo y su sobrino (6: $4 \mathrm{I}-42$. El oficio de los obispos).

30. Amor y Temor (7: 45-46. La primera intención).

3I. El alcalde lujurioso (7: 46. El mal gobernante y el mal pueblo).

32. La doncella casta tentada (7: $46-47$. El pecado ocasiona más pecados).

33. El predicador incompleto (7: 47-48. El conocimiento de los artículos de la fe).

34. El ermitaño tentado (7: 48. La segunda intención).

35. El pastor y el filósofo (7: 48. Cada uno tiene su oficio).

36. El rico con dos pecados (7: 48-49. El modo de vencer la tentación).

37. El pagano y los tres sabios (7: 49-5o. La Encarnación).

38. El mensajero muerto (7: 5 O. Los vasallos que sirven al señor).

39. El rey y el conde (8: $5 \mathrm{O}-53$. El ejemplo de Jesucristo).

40. El escudero y el caballero (8: $5^{\mathrm{I}-} 5^{2}$. El buen cristiano, buen ciudadano).

4I. El conde y el hortelano (8: 53-54. Los vanagloriosos de su oficio).

42. El burgués que lo dejó todo (8: 54 . La renuncia al mundo).

43. El castillo del hijo del rey (9: 55. La herencia de Adán y los reyes).

44. El hijo del buen rey (9: 56 . El libre albedrío).

45. El hermano del rey respetuoso (9: 56 -57. El pecado de orgullo).

46. El maestro y el monaguillo (IO: 57. La virginidad de María).

47. El burgués celoso (IO: 58. Por qué María sobrevivió a Jesucristo).

48. La hija del rey (Io: 59. La justicia del cielo).

49. La corte del hijo del rey (пі: 59-6o. La venida de Jesucristo).

50. Los dos obispados (II: 6o. La actitud de Jesucristo y de los hombres).

5I. El buen rector y los malos monjes (II: 6r. La voluntad de los hombres y Jesucristo).

52. Los dos sabios judíos (ІІ: 6r. El cautiverio de los judíos).

53. El cristiano usurero (II: 6r. La segunda intención).

54. Los judíos conversos y el rey (пг: 62. Los malos usos de los reyes con los judíos).

55. El cristiano que asesinó a un judío (II: 62. Los malos usos de los reyes con los judíos).

56. La centella de fuego (I2: 62-63. La capacidad de conversión de los apóstoles).

57. El rey y el campesino (I2: 63-64. La voluntad de Dios y de los hombres).

58. El obispo y el mal clérigo (I2: 63-64. La perversión de los hombres).

59. Voluntad y Poder (I2: 64. Las dignidades divinas y creadas).

6o. El sabio y el rico (I2: 64. La voluntad de los hombres).

6r. El entierro de un rico (I2: 64. El respeto a los símbolos).

62. El peregrino ante la cruz (I2: 64-65. El respeto a los símbolos). 
63. El rey que jugaba a ajedrez (ı2: 65. La ociosidad de los hombres y Dios).

64. Poder, Sabiduría y Voluntad (I2: 65. Las dignidades divinas y creadas).

65. El sultán y la Tierra Santa (I2: 65 . La nueva cruzada).

66. Los envidiosos de la corte (i2: 66. La venida de Jesucristo).

67. El predicador del Anticristo (I2: 66. La venida del Anticristo).

68. El palacio que se derrumbaba (I2: 67. La voluntad de Dios y de los hombres).

\section{Libro segundo}

69. El hijo mayor y el menor (I3: 7O. La relación entre Dios y los ángeles).

7O. El rey ignorante (I3: 7O-7I. El oficio de los ángeles).

7I. El religioso y el rey (I4: 7. El oficio de los ángeles).

72. El filósofo, el jurista y el peregrino (I5: 73. La imaginación de los ángeles).

73. El monaguillo vanidoso (I5: 73-74. El conocimiento de los ángeles).

74. El caballero, el clérigo y el castillo (i5: 74. El conocimiento de los ángeles).

75. El religioso tentado por el demonio (i6: 74. El conocimiento de los ángeles).

76. El pastor que soñaba (i6: 75. La locución angélica).

77. El mal alcalde (I6: 75. La locución angélica).

\section{Libro tercero}

78. El palacio del rey noble (I7: 78. La caracterización del sol).

79. El rey que juzgaba a un caballero (I8: 8o. El poder de Dios).

8o. La luz de la candela (ı8: 8o. El movimiento de las estrellas).

8I. El filósofo y el buey (I8: 80-8I. La vida ajena al mundo).

82. El filósofo y el monaguillo (I8: 8г. La influencia del sol en los hombres).

83. La mujer que se maquillaba (I8: 82-83. El crecimiento del sol y de la luna).

84. La mujer maravillada (I8: 83. La sombra de la luna).

\section{Libro cuarto}

85. El mal rey y el peregrino (I8: 84. Los honores a Dios y a los reyes).

86. Los grados de la pimienta (ı9: 85-86. La composición de los elementos).

87. La justicia y el pecador (20: 86. La generación de los elementos).

88. El vino en un vaso de agua (2r: 88. El movimiento de los elementos).

89. El filósofo y los monaguillos (22: 89. La naturaleza del rayo).

90. El maestro y el monaguillo (22: 89. El movimiento del rayo).

9I. El maestro y el monaguillo (22: 89. La luz del rayo).

92. El rey que asediaba un castillo (23: 90. La naturaleza del trueno).

93. El pastor en la montaña (24: 9O-9I. La naturaleza de las nubes).

94. El hombre y el sabio (27: 93. La naturaleza del viento).

95. El gallo, las gallinas y la zorra (29: 98. La percepción de la realidad).

96. El matrimonio y la serpiente (29: 99. La interpretación de la realidad).

97. El lujurioso y su hijo (29: 99. La injusticia en el mundo).

\section{Libro quinto}

98. Los dos hijos del burgués (29: IO2-IO3. La vida activa y la contemplativa).

99. El arte del filósofo (29: Ioz. La vida contemplativa).

IOO. El pastor y el filósofo (3O: IO3-IO4. El crecimiento de los árboles).

IOI. El ágape del rey y de los caballeros (30: IO4-IO5. La condena de la humanidad). 
IO2. El cambista rico (3I: Io6. La poda de los árboles).

IO3. La disputa del cristiano y del sarraceno (3I: Io6. La corrupción de los árboles).

IO4. El obispo, el caballero y el loco (3І: Iо6-го7. Los frutos de los árboles).

I05. Los dos manzanos (3I: IO7. Los frutos de los árboles).

Io6. La mujer del mercader (3I: IO7-IO8. La corrupción física de los hombres).

IO7. El burgués y su hijo (32: IO8-IO9. La virtud de Dios).

IO8. Los diez mil besantes perdidos (32: IO9. La nutrición de los hombres).

Io9. El canónigo y el hereje (32: IIO-III. Por qué los animales saben qué comer).

\section{Libro sexto}

IIO. El maestro y el monaguillo (33: II4. La naturaleza del oro y del hierro).

III. La cuestión entre el hierro y la plata (34: II4. La necesidad del hierro y de la plata).

II2. La mujer bella y la fea (34: II5. La necesidad del hierro y de la plata).

II3. La honra del mercader (34: II6. El oro y la plata por encima de Dios).

II4. Los mil besantes del ciego (34: II6. El oro y la plata por encima de Dios).

II5. La iglesia de la bella cruz (35: II7-II8. La atracción del hierro y del imán).

II6. El rey lujurioso (35: ıI8. El fuego que funde el hierro).

II7. La mujer y el médico (35: II8-II9. La plata que resuena más que el hierro).

II8. La mujer y el pobre (35: I20. La solidez del oro es superior a la del hierro).

II9. El alquimista y el fuego (36: I2I-I22. La naturaleza de la alquimia).

I2O. El combate del león y del jabalí (36: 122. La naturaleza de la alquimia).

I2I. El hombre que quería ser rico (36: I22. La necesidad de la alquimia).

I22. El matrimonio rico sin hijos (36: I22-I23. La necesidad de los alquimistas).

\section{Libro séptimo}

I23. La elección del obispo (37: ı28. La elección del rey de los animales).

I24. Los apóstoles (38: I30. La elección de consejeros humildes).

I25. El combate del conde y el rey (38: Ізг. La elección de consejeros humildes).

I26. El cristiano confiado en un sarraceno (39: I3I-I32. La enemistad entre animales).

I27. El ermitaño, el milano y la rata (39: I32. La propia naturaleza no se traiciona).

I28. Las segundas nupcias del caballero (39: I33. La propia naturaleza no se traiciona).

I29. Los sacrificados por un león (39: I33-I34. La propia naturaleza no se traiciona).

I30. Los dos hijos del rey (39: 134. La propia naturaleza no se traiciona).

I3I. Eva y la serpiente (39: I35. La propia naturaleza no se traiciona).

I32. El mal consejo del mal rey (40: I35-136. El mal consejo).

I33. El obispo pecador (40: I36. La prevención contra los malos consejos).

I34. El mal rey y el ermitaño (40: I36-I37. La prevención contra los malos consejos).

I35. El adufe del juglar (40: I37-I38. El miedo a lo que se ignora).

I36. El cuervo y la serpiente (40: I39. La falta de miedo).

137. El cangrejo y la garza (40: 139. El instinto de subsistencia).

I38. El santo hombre y el rey (40: I40. La expulsión de los malos consejeros).

I39. El oso, el cuervo y la serpiente (40: I4O. La falsedad de la serpiente).

I40. La disputa de Fuerza y Maestría (4O: I43. Los animales que tratan a los hombres).

I4I. El matrimonio burgués y la loca (4I: I44. La lujuria de los hombres).

I42. El combate de los dos machos cabríos (4I: I44. La lujuria de los hombres).

I43. El casamiento de la hija del rey (4I: I45-I46. La injuria de los hombres).

I44. El heredero del burgués rico (4I: I5O. La responsabilidad de los hombres). 
I45. La reina y la falsa doncella (4I: I5I. El temor de los hombres).

I46. La zorra y la asadura (42: I53. Los mensajes de la serpiente).

I47. La hija del campesino y el caballero (42: I55. La previsión de la muerte del buey).

I48. El hombre que entendía a los animales (42: I56-I57. La reforma del consejo).

I49. El papagayo y el cuervo (42: I58. La reforma del consejo).

I50. El jabalí y el rey (43: I59-I6o. El deseo de magnicidio).

I5I. Los barones despreciados por el rey (43: I6I. Los motivos de la traición).

\section{Libro octavo}

I52. El burgués que mantenía un albergue (43: I65. Los estamentos sociales).

I53. El burgués que honraba a Dios (43: I65. Los estamentos sociales).

I54. El príncipe y los dos caballeros (43: I66. La conducta).

I55. El oficio de ermitaño (43: I67. La paciencia del hombre).

I56. La mujer del burgués y el villano (46: I73-I74. El amor a Dios).

I57. El mal obispo y el entierro (47: I76. Las consecuencias del pecado).

I58. El hijo indiferente a la muerte del padre (48: I77. La vanagloria de los hombres).

I59. Los entuertos que no deshizo un usurero (48: i78. La vanagloria de los hombres).

I60. El prior lujurioso (49: I80-I8I. La enfermedad en los hombres).

I6I. El hijo del rey triste y el alegre (49: I80-I8I. La enfermedad en los hombres).

I62. El maestro y el monaguillo en el molino (50: I8I-I82. La vejez en los hombres).

I63. Los dos asnos del arriero (50: I82. La vejez en los hombres).

I64. La forma y la materia de la nave (5I: I83. La muerte corporal y la espiritual).

I65. El hombre que amaba a su hijastro (5I: I84. La corrupción del cuerpo).

I66. La datilera quemada (5I: I84-I85. La muerte del alma).

I67. El rey que deseaba amar a su hijo (5I: I85. La mortalidad de los hombres).

I68. El hijo del caballero en el extranjero (53: I86-I87. La finalidad en Dios).

I69. El maestro y el monaguillo (53: I87. El placer del pecado).

I70. El mercader que quería lluvia (53: 187. El placer del pecado).

I7I. El monaguillo que no quería aprender (54: I88. La finalidad de los hombres).

I72. El duelo de los padres por su hijo (55: I9O. La falta de deseo de Dios).

I73. El hijo del usurero (55: I9O-I9I. Los hombres que actúan contra natura).

I74. Los malos canónigos (56: I92-I93. El placer de los hechos espirituales).

I75. El canónigo y la prostituta (56: I92-I93. El placer de los hechos espirituales).

I76. El rey y el juglar adulador (57: I94-I97. Renegar de Dios).

I77. El ermitaño penitente (57: I95-I97. Renegar de Dios).

I78. El combate del león y la serpiente (57: I96-I97. Renegar de Dios).

I79. La mujer que se maquillaba (58: 198 . El hedor de los condenados al infierno).

I80. La mujer y el bello jardín (58: I98-199. El hedor de los condenados al infierno).

I8I. El obispo y el escudero (59: I99-2OI. El placer de comer).

I82. El obispo pomposo y el ermitaño (59: 200. El placer de comer).

I83. El príncipe y los religiosos (59: 2OI. El placer de comer).

I84. El burgués y el pobre (59: 20I. El placer de comer).

I85. La mujer del caballero (6o: 203. Los deseos de los hombres).

I86. La buena mujer y el mal confesor (6o: 203. El dolor y la enfermedad).

I87. El peregrino y la pasión de Cristo (60: 204. Los hombres sienten lo que quieren).

I88. El debate de Bondad y Maldad (6r: 206. Los malos hombres).

I89. El ermitaño tentado (6r: 2O7. Los malos hombres). 
I90. La mujer lujuriosa (6r: 2O7. El bien de los malos hombres).

I9I. La buena mujer del lujurioso (6I: 208. El placer del bien).

I92. El monje que quería ser rector (62: 208-209. La vida activa y la contemplativa).

193. El obispo que no quería serlo (62: 209-2IO. La vida activa y la contemplativa).

194. El ermitaño que hizo vida activa (62: 2IO. La vida activa y la contemplativa).

195. El religioso activo y contemplativo (62: 2IO. La vida activa y la contemplativa).

I96. El hombre que se dio a Dios (63: 2II. La fe).

197. El príncipe que cazaba un jabalí (63: 2I2. La fe).

I98. El juglar de Dios (63: 2I2-2I3. La predicación a los infieles).

199. El rey joven y el rey viejo (64: 2I4. La falta de esperanza).

2OO. El hombre con 7 pecados mortales (64: 2I4-2I5. La esperanza de los pecadores).

2OI. El príncipe que sufría por Dios (64: 2I5. La esperanza en Dios).

202. El pecador redimido (64: 2I6. La esperanza en Dios).

203. El cristiano, el judío y el sarraceno (64: 2I6. La esperanza en Dios).

204. El rey y el escudero (64: 2I6-2I7. La desesperanza de los cristianos).

205. El obispo ostentoso (65: 218. La caridad).

206. El obispo avaro (65: 2r8-2r9. La faltad de caridad en el mundo).

207. El pobre que llegó a una villa (65: 219. La falta de amor a Dios).

208. El mal juez y el zapatero (66: 220-22I. La justicia de Dios).

209. El rey poderoso y el campesino (66: 22r. La justicia de Dios).

2IO. El rey saludable (66: 22I. La justicia de Dios).

2II. El pecador arrepentido (66: 22I. La justicia de Dios).

2I2. El hijo del usurero (66: 22I. La justicia de Dios).

2I3. El veguer y la sentencia del hijo (66: 22г. La justicia de Dios).

2I4. El rey y la sentencia del campesino (66: 222. La justicia de Dios).

2I5. El rey que cazaba un jabalí (67: 223. La sabiduría de Dios).

2I6. El burgués irreverente (67: 223 La sabiduría de Dios).

2I7. El rey que no tenía cuidado de Dios (67: 224. La locura).

218. El loco y el sabio (67: 224. La locura).

219. El loco y el sabio religioso (67: 225. La locura).

220. El encuentro de Sabiduría y Locura (67: 225. La mayor sabiduría del mundo).

221. El testamento del avaro (67: 225. La mayor sabiduría del mundo).

222. El suicida por celos (67: 225. La mayor sabiduría del mundo).

223. Los dos locos de la corte (67: 226. La mayor sabiduría del mundo).

224. El grano de trigo (67: 226. Las locuras por dinero).

225. El loco que no quería a Dios (68: 227. El poder del alma).

226. El loco vicioso (68: 227. El poder del alma).

227. El hombre que no quería a su mujer (68: 227. La debilidad de los hombres).

228. El hombre que no quería a su mujer (68: 228. La debilidad de los hombres).

229. El pecador arrepentido (68: 228. El poder de los hombres para amar a Dios).

230. El rey poderoso y pecador (68: 228. La posibilidad de pecar).

23I. Las debilidades del santo (68: 228-229. La debilidad de los hombres).

232. El pecador que no quería pecar (68: 229. La renuncia al pecado).

233. Sabiduría, Voluntad y Poder (68: 229. La renuncia al pecado).

234. El filósofo y el maestro de teología (69: 23o. La temperancia de los hombres).

235. El prelado mal acostumbrado (69: 230-23r. Los efectos de la temperancia).

236. El religioso contemplativo (69: 23I. Los efectos de la temperancia). 
237. El príncipe temperado (69: 23I. Los efectos de la temperancia).

238. El rey vanaglorioso (70: 233 . Los efectos de la avaricia).

239. El heredero y los pobres (70: 233. Los efectos de la avaricia).

240. Los cinco hijos del rey (70: 233-234. Los efectos de la avaricia).

24I. La pobreza del mal caballero (70: 234. Los efectos de la avaricia).

242. El peregrino en Tierra Santa (70: 234. Los efectos de la avaricia).

243. Generosidad y Avaricia (7O: 234. Los efectos de la avaricia).

244. Las gallinas del avaro (70: $234-235$. Los efectos de la avaricia).

245. La virgen y el viejo lujurioso (7I: 235. Los efectos de la lujuria).

246. La mujer casta y el obispo lujurioso (7I: 236. Los efectos de la lujuria).

247. La mujer del caballero y el rey (7I: 237. Los efectos de la lujuria).

248. Castidad y Lujuria (71: 237. Los efectos de la lujuria).

249. El pecador impaciente (72: 239. La acidia en el mundo).

250. El burgués que comía y bebía (72: 239. La acidia en el mundo).

25I. El peregrino en Tierra Santa (72: 239-240. La acidia en el mundo).

252. El hospital mal gobernado (72: 240. La ignorancia de la acidia).

253. El orgulloso y el sabio (73: 24I-242. La humildad de Jesucristo).

254. Los religiosos y el rico (73: 242. La humildad de Jesucristo).

255. La bella mujer del campesino (73: 243. El orgullo de los hombres).

256. Grandeza y Parquedad (73: 243. El orgullo de los hombres).

257. El hijo del zapatero rico y avaro (73: 243. El orgullo de los hombres).

258. El hijo orgulloso del rey (73: 24I-242. El orgullo de los hombres).

259. Los dos caballeros y el príncipe (73: 243-244. El orgullo de los hombres).

260. El devoto y el rey (73: 244. El orgullo de los hombres).

26I. El rey y los caballeros (74: 244-245. El servicio a Dios).

262. El campesino pobre y el caballero rico (74: 245. El servicio a Dios).

263. El obispo vicioso y el rey (74: 245. Los vicios humanos).

264. Los dos escuderos del caballero (74: 245-246. El servicio a Dios).

265. El sobrino del obispo (74: 246. El servicio a Dios).

266. Envidia y Continencia (74: 246. El servicio a Dios).

267. El burgués envidioso (74: 246. El servicio a Dios).

268. El arriero continente (74: 246. El servicio a Dios).

269. El loco y el sabio (75: 247-248. La superación de la ira).

270. El rey traicionado por su pueblo (75: 248-249. La superación de la ira).

27I. El pobre que daba a conocer a Dios (75:249. La superación de la ira).

272. El mal príncipe y el burgués rico (75: 249-250. La paciencia y la fortaleza).

273. Los dos hijos de un hombre (76:25I. Los bienes temporales).

274. Los dos pecadores ( $76: 25^{\mathrm{I}-25^{2}}$. Los bienes temporales).

275. El buen rey y el emperador injusto ( $66: 25^{2}$. La justicia de Dios).

276. El castillo del rey ( $76: 25^{2}$. La justicia de Dios).

277. La rueda del hortelano (76: $25^{2}$. La justicia de Dios).

278. El perro y el pastor (76: 252. Los hombres buenos y malos).

279. El mal pueblo del buen rey (77: 254. La deslealtad).

280. Los cachorros y el lobo (77: 254-255. La deslealtad).

28I. El matrimonio sin hijos (77: 255. La deslealtad).

282. El escudero y la mujer del barón (77: 255. La deslealtad).

283. El burgués lujurioso (78: 256-257. La falta de servicio a Dios). 
284. La mujer casta malhablada (78: 257. La falta de servicio a Dios).

285. El pobre en la mesa del barón (78: 257. La falta de servicio a Dios).

286. El orgulloso malhablado (78: 257. La falta de servicio a Dios).

287. El santo que decía la verdad (79: 258. La falsedad).

288. El gentil y los tres sabios (79: 259. El poder de la falsedad).

289. El ermitaño y Verdad (79: 26o. La vergüenza a la verdad).

290. El falso testimonio del pobre (79: 260. La vergüenza a la verdad).

29I. El clérigo y la Trinidad (79: 26I. La vergüenza a la verdad).

292. El sobrino del obispo (80: 262. La culpa y la justicia).

293. El rey enemistado con Dios (80: 262-263. La culpa y la justicia).

294. El condenado a muerte por el rey (80: 263 . La culpa y la justicia).

295. El rey poderoso y rico (8o: 263 . La culpa y la justicia).

296. El obispo y la bondad de Dios (80: 263-264. La culpa y la justicia).

297. Los dos caballeros (8o: 264. La culpa y la justicia).

298. El clérigo y el lego pecadores (80: 264. La culpa y la justicia).

299. Los dos panes del hornero (80: 264. La proporción del mérito).

30o. El creyente y el pecador (80: 265. La proporción del mérito).

30I. Los predicadores del Evangelio (8г: 265. El cuerpo sometido al alma).

302. El rico y el pobre (8г: 266. El cuerpo sometido al alma).

303. El lujurioso arrepentido (8I: 266. El cuerpo sometido al alma).

304. El rey y la Tierra Santa (8I: 266-267. El cuerpo sometido al alma).

305. El religioso tentado (8г: 267 . El cuerpo sometido al alma).

306. El prior vicioso (8ז: 267. La obediencia).

307. El cristiano y el judío (8I: 267-268. La obediencia).

308. El religioso vanaglorioso (8I: 268. La obediencia).

309. La mujer infiel (8I: 268. La obediencia a los demonios).

3IO. El religioso y el burgués ociosos (82: 27I. El orden del poder de Dios).

3II. Los dos dineros (83: 272-273. La renuncia a la riqueza espiritual).

3I2. El hombre que amaba los dineros (83: 273. La renuncia a la riqueza espiritual).

3I3. El burgués rico y orgulloso (83: 274. La pobreza de los condenados).

3I4. El miedo a la muerte del rey (83: 274. La pobreza de los condenados).

35. El rey con poco entendimiento (83: 274. La pobreza de los condenados).

3i6. La piedra preciosa del pobre (83: 275. La pobreza de los condenados).

3I7. El lujurioso y el ermitaño (84: 276. La servidumbre del pecado).

3I8. El trono del rey (84: 276-277. La pena del alma en el infierno).

39. La libertad del pueblo (84: 277. La servidumbre del pecado).

320. Los malhechores protegidos (84: 277. La servidumbre del pecado).

32I. El buen hijo amado (85: 278-279. Las diferencias de los pecadores).

322. El bello rey vanaglorioso (85: 279. La semejanza a Dios).

323. El rey cazador en la ermita (85: 279-28o. El amor a la semejanza).

324. El rey envenenado (85: 280. El amor a la semejanza).

325. El pintor alabado (86: 28o. La alabanza a Dios).

326. El judío preferido del rey (86: 28I. Los que no alaban a Dios).

327. El que predicaba a los sarracenos (86: 282. Los pocos que alaban a Dios).

328. El rey y el mercader (86: 282. La alabanza a Dios).

329. El rey y los juglares (86: 282-283. La alabanza a Dios).

33o. El fuego calienta los elementos (87: 284-285. La perfección del alma). 
33I. El rey que no tenía hijos (87: 285. La imperfección de los hombres).

332. El mercader que quería ser rico (87: 285. La imperfección de los hombres).

333. El fuego calienta el agua (87: 285-286. La satisfacción del alma).

334. El príncipe noble y poderoso (88: 287. El entendimiento de los hombres).

335. La mujer deseada por el rey (88: 288. La participación del alma).

336. El rey poderoso sin sabiduría (88: 288-289. La nobleza de Dios).

337. El hombre que removía la tierra (88: 289. La relación de voluntad y poder).

338. El filósofo que buscaba la sabiduría (88: 290. La voluntad mundanal).

339. El hombre que quería ser bueno (88: 290-29I. El crecimiento de la bondad).

340. El rey que quería ser honrado (88: 29I. El crecimiento de la bondad).

34I. El hombre que se dirigía al rey de Francia (88: 29I. El crecimiento de la Iglesia).

342. El mercader que perdió sus dineros (90: 292. Ganar o perder).

343. El mercader con mala mercancía (90: 293. Ganar o perder).

344. El hombre que perdió a su hijo (90: 294. Ganar o perder).

345. Los jugadores de ajedrez (90: 294. Ganar o perder).

346. El hijo que murió en pecado (90: 294. Ganar o perder).

347. Los religiosos y los infieles (90: 294. Ganar o perder).

348. La batalla del rey y el emperador (90: $295^{-296}$. El falso ardid).

349. El caballero cristiano y el sarraceno (90: 296 . El falso ardid).

350. La guerra del marqués y del conde (9o: 296. El falso ardid).

35I. El hombre que amaba a su señor (90: 296. El falso ardid).

352. Los dos cristianos presos (9o: 296-297. El falso ardid).

353. El religioso y los sarracenos (90: 297. El riesgo de amar a Dios).

354. El combate del caballero y del escudero (90: 297. El riesgo de amar a Dios).

355. El caballero y su enemigo (90: 298. El riesgo de amar a Dios).

356. El combate entre reyes (9o: 298. El riesgo de amar a Dios).

357. El hombre que advertía a los regidores (90: 298. El riesgo de amar a Dios).

35\%. La mujer del burgués humilde (92: 299. La honra).

359. El mal prelado poderoso (92: 299-30o. La honra).

36o. El obispo hijo de un campesino (92: 30o. La honra).

36r. El príncipe vanaglorioso (92: 300-30r. La honra).

362. La mujer que vestía noblemente (93: 304. La belleza de Jesucristo).

363. La belleza de la comunión (93: 304. La belleza de Jesucristo).

364. La bella mujer orgullosa (93: 305. La belleza de Jesucristo).

365. El mozo hijo de un burgués (94: 305. La consolación).

366. El ermitaño y el pecador (94: 305-3o6. La consolación).

367. El mercader que lo perdió todo (94: 306. La consolación).

368. La mujer infiel (94: 306-307. La consolación).

369. El burgués que perdió un hijo (94: 307. La consolación).

370. El peregrino y el clérigo (94: 307. La consolación).

37I. El caballero vencedor y el vencido (94: 307. La consolación).

372. El mal rey abandonado (94: 307-308. La consolación).

373. El mercader moribundo (94: 308. La consolación).

374. El avaro rico que moría (94: 308. La consolación).

375. El gentil que pensaba en la muerte (95: 309. El alma que pierde el gozo de Dios).

376. La madre que amamantaba a su hijo (95: 309. El alma que pierde el gozo de Dios).

377. Los dos hermanos (95: 309-3IO. El alma que pierde el gozo de Dios). 
378. El hijo del mercader en el extranjero (95: 3ІІ. La tristeza de los condenados).

379. La madre que perdió a su hijo (95:3II. La tristeza de los condenados).

380. El sueño del paraíso (95: 3II. La tristeza de los condenados).

38I. El poder y el honor del rey (96: 313. La concordancia).

382. El rey contra su pueblo (96: 3I3. La contrariedad).

383. Los grandes saltos del caballero (97: 3I5. La grandeza de Dios).

384. El buen rey y los malos súbditos (97: 3I5. La finalidad de la creación).

385. El orgulloso y el pobre (97: 316. La finalidad de la creación).

386. El caballero lujurioso y avaro (97: 316. La finalidad de la creación).

387. El escudero que se hizo templario (97: 316. La finalidad de la creación).

380. La finalidad de las acciones (97: 3І6. La finalidad de la creación).

389. El hombre y los dineros (97: 316-3I7. La finalidad de la creación).

390. El sabio y el filósofo (97: 317. La finalidad del mundo).

39I. Los dos caminos (97: 317. Dios lo sabe todo).

392. El avaro rico (98: 318. Los hombres son mundanales).

393. El pueblo atemorizado por su rey (98: 318. Los hombres son mundanales).

394. El príncipe que tenía que ser bueno (98: 3I8. Los hombres son mundanales).

395. El procurador del monasterio (97: 318-3I9. El triunfo de los malos hombres).

396. El burgués vanaglorioso (98: 319. La mejoría de los hombres).

397. El rey mundanal (98: 319. Los que no aman a Dios).

398. Bondad y Grandeza (98: 319-320. La falta de sabiduría en el mundo).

399. El testamento de los dos hijos (98: 320. La falta de sabiduría en el mundo).

400. El pecador que hacía contrición (99: 32I-322. El alma mundanal).

4OI. El comilón (99: 322. El alma mundanal).

402. El marido celoso de su mujer (99: 322. El alma mundanal).

403. El abad que envidiaba una villa (99: 322. El alma mundanal).

4O4. El zapatero y el peletero (99: 322-323. El alma mundanal).

405. El rey cazador (99: 323. El alma mundanal).

406. El hombre que hablaba demasiado (99: 323. El alma mundanal).

4O7. El hombre que no entendía a Dios (IOO: 324. La predestinación).

408. El maestro y el monaguillo (IOO: 325. La sabiduría y la justicia de Dios).

409. El hombre y el prelado (IOO: 326. La predestinación).

4IO. El hombre tentado (IOO: 327. La predestinación).

4II. La fiesta del rey poderoso (IOI: 328 . La abstinencia).

4I2. El prelado y el clérigo (IOI: 329. La abstinencia).

4I3. El comilón (IOI: 329. La abstinencia).

4I4. La mujer del cruzado (IoI: 329. La abstinencia).

4I5. El maestro y el monaguillo (IOI: 329-330. La abstinencia).

4I6. El capítulo de la abadía (IO2: 330. La conciencia).

4I7. El obispo de un rico obispado (IO2: 33I. La conciencia).

4I8. El mal abogado (IO2: 33I-332. La conciencia).

4I9. El príncipe y el pobre (IO2: 332. La conciencia).

420. El príncipe ocioso (IO2: 332-333. La pérdida de conciencia).

42I. El clérigo sin buenos consejos (IO3: 333. La confesión).

422. El lujurioso arrepentido (IO3: 333-334. La confesión).

423. El presbítero y la prostituta (IO3: 334. La confesión).

424. El pecado oculto (IO3: 334. La confesión). 
425. El confesor del rey (IO3: 334-335. La confesión).

426. El lego que vivía en un monasterio (Io3: 335. La confesión).

427. El peregrino y el emperador (IO3: 335. La confesión).

428. El prelado que no actuaba (IO3: 335. La confesión).

429. La confesión de un caballero pobre (IO3: 335. La confesión).

430. La confesión de las lujuriosas (IO3: 336. La confesión).

43I. El mal caballero y el orden (IO4: 336-337. La falta de penitencia).

432. El santo en el desierto (IO4: 337. La penitencia del cuerpo y del alma).

433. El religioso devoto escogido obispo (IO4: 337. Los religiosos que no hacen penitencia).

434. El monje escogido obispo (IO4: 338. Los religiosos que no hacen penitencia).

435. El hombre que no hacía penitencia (IO4: 338. Los religiosos que no hacen penitencia).

436. El hombre corajudo (IO4: 338. La verdadera penitencia).

437. El grano de semilla (IO5: 339. Los efectos de la oración).

438. El avaro y la oración del ermitaño (IO5: 339. Los que no adoran a Dios).

439. El príncipe que hacía amar a Dios (IO5: 340. Los que no adoran a Dios).

440. El trapero rico (IO5: 340. Los que no adoran a Dios).

44I. El niño del monasterio (IO5: 340. Los que no adoran a Dios).

442. El preso que vivía de la caridad (IO5: 34I. Los que permiten el mal a Dios).

443. El burgués rico y el peregrino (Io6: 34-342. La caridad).

444. El obispo que hacía caridad (Io6: 343. Los ricos que no hacen caridad).

445. El pobre que mendigaba (Io6: 343 . Los ricos que no hacen caridad).

446. El hijo y el hijastro (Io6: 343-344. Los ricos que no hacen caridad).

447. La crítica del obispo (Io6: 344. Los ricos que no hacen caridad).

448. El caballero y el pobre (Io6: 344. Los ricos que no hacen caridad).

449. El obispo rico y el pecador (IO7: 345. La intención de Dios).

450. El príncipe mundanal (IO7: 345. La intención de Dios).

45I. El santo maravillado (IO7: 346. La primera y la segunda intención).

452. El abad que quería ser el más sabio (IO7: 345. La intención del alma).

453. El maestro y el monaguillo (Io8: 347-348. La tentación).

454. El buen monje y los malos (Io8: 348. La tentación).

455. El mal hombre (Io8: 348-349. La tentación).

456. El ermitaño ocioso tentado (Io8: 349. La tentación).

457. El canónigo orgulloso (Io8: 349-350. La tentación).

458. El hombre tentado (Io8: 35 o. La tentación).

459. El sabio tentado (Io8: 350. La tentación).

460. El obispo vanaglorioso (Iog: 35 I. La vanagloria de los hombres).

46I. El ermitaño y el pobre (Io9: 35. La vanagloria de los hombres).

462. El caballero mal y bien vestido (Iog: $35^{\mathrm{I}}-35^{2}$. La vanagloria de los hombres).

463. El obispo vanaglorioso (Io9: 352. La vanagloria de los hombres).

464. El clérigo vanaglorioso (Io9: 352-353. La vanagloria de los hombres).

465. La dama vanagloriosa (Io9: 353. La vanagloria de los hombres).

466. El hijo del caballero (Io9: 353. La vanagloria de los hombres).

467. El castillo del caballero (Io9: 353. La vanagloria de los hombres).

468. El obispo que edificaba (IIO: 354. Las obras de los hombres).

469. El rey que edificaba (піо: 354-355. Las obras de los hombres).

47O. El castillo del mal caballero (IIO: 355 . Las obras de los hombres).

47. El albergue del mercader rico (IIO: 355. Las obras de los hombres). 
472. El hijo del rey sabio (III: 356-357. El buen regimiento).

473. El mal conde (III: 356. El buen regimiento).

474. El alcalde corrupto (III: $35^{6-357 .}$. El buen regimiento).

475. El ermitaño que iba por el mundo (III: 357. El buen regimiento).

476. El rey enfrentado a su pueblo (III: 357 . El hombre que rige un pueblo).

477. El grano de trigo (III: $357^{-358}$. El hombre que rige un pueblo).

478. El mal emperador y el buen rey (III: 358. El hombre que rige un pueblo).

479. El mal príncipe (III: 358. El hombre que rige un pueblo).

480. El príncipe que no era justo (II2: 358. La elección de los gobernantes).

48I. Los dos monjes y el obispo (II2: 359. La elección de los gobernantes).

482. La lucha por ser alcalde (II2: 359. La elección de los gobernantes).

483. El sobrino del obispo (II2: 359. La elección de los gobernantes).

484. El canónigo y el sacristán (II2: 359-36o. La elección de los gobernantes).

485. Los dos clérigos vanagloriosos (II2: 360 . La elección de los gobernantes).

486. El abad avaro (II2: 360. La elección de los gobernantes).

487. Los dos clérigos y el obispo (II2: 360. La elección de los gobernantes).

488. El obispado del canónigo (II2: 360. La elección de los gobernantes).

489. El burgués rico (II2: 36I. Las malas elecciones).

490. El rey y el otro mundo (II3: 362. La perversión de la creación).

49I. El pastor y el pobre (II3: 362 . El pecado en el alma).

492. El hortelano y la rueda (II3: 362. La perversión del pecado).

493. El obispo y el archidiácono avaros (II3: 363-364. Los hombres pueden pecar).

494. El cristiano y el judío (II4: 365. La restitución del cuerpo).

495. El gentil y la otra vida (II $4: 365-366$. La restitución del cuerpo).

496. El gusano de seda (II4: 365. La restitución del cuerpo).

497. El caballero injuriado por el rey (II4: 366. Los creyentes pueden pecar).

498. El cristiano y el sarraceno (II5: 367-368. La creencia en la Trinidad).

499. El sarraceno cautivo de los cristianos (II5: 368. Los que no aprecian el espíritu).

50o. El filósofo en la montaña (II5: 368-369. Los que no perciben el pecado).

\section{Libro noveno}

5OI. La contrariedad del fuego y del agua (II6: 372. Los elementos y las dignidades).

502. La esencia del fuego (II7: 376. La gloria del alma).

503. El obispo vanaglorioso (II7: 376. La segunda intención).

504. El hierro en la fragua (ir8: 377 . El cuerpo glorificado).

505. La contrariedad de los elementos (II8: 378. El cuerpo glorificado).

506. El matrimonio y su hijo (iı8: 379. La gloria del cuerpo y del alma).

\section{Libro décimo}

5O7. El padre deshonrado (II9: 38г. Los demonios y Dios).

508. La forma y la materia del fuego (ıig: 383 . La pena de los demonios).

509. La mala mujer (II9: 383. El comportamiento de los demonios).

5 IO. El avaro (II9: 383 . El comportamiento de los demonios).

5II. La simplicidad del fuego (I20: 384 . La pena del alma).

5². La muerte del hijo (I20: $3^{8} 5$. La acumulación de las penas infernales).

53. El rey mentiroso (I2O: 385 . La pérdida de la gloria eterna).

514. El obispo simoníaco (120: 386 . El temor al infierno). 
515. Los poderes del rey (I2I: 386 . La acumulación de las penas infernales).

516. El vaso de vino (І2 I: 387 . La acumulación de las penas infernales).

51\%. El hospital derrumbado (I2I: $38 \%$. El temor al infierno).

518. El clérigo perezoso (I2I: 388. Los malos cristianos contra otros malos cristianos).

59. El clérigo lujurioso (I2I: 388 . La superación de la lujuria).

520. El usurero sediento (I2r: 389. Los que escogen la condena eterna).

\subsection{Libro de santa María}

(III.7 - Llibre de santa Maria [ı290-2 (?)]. Total ejemplos: I3I. Carreras, Batllori, Carreras, Rubió i Balaguer I957-I960, I, II43-I242 [OE, I, II43-I242]).

Título (capítulo:pág. Tema).

I. El árbol y el fruto (prólogo: II55-6. La primera y la segunda intención).

2. La ciudad mundana (prólogo: II56. La decadencia del mundo).

3. Cuando Roma gobernaba el mundo (prólogo: II57. La utilidad común).

4. El hombre de la ermita con una fuente (prólogo: II57-8. La virgen María).

5. El sabio que abandonó el mundo (prólogo: in58-9. La virgen María).

6. El sol no tiene tinieblas (I: II6o. La bondad de María).

7. El hombre que puede ver (I: II6o. La bondad de María).

8. El canónigo enfermo (I: II60-I. La bondad de María).

9. $\quad$ El sol que ilumina (I: II6I-2. La bondad de María).

IO. Las mujeres que tenían un hijo y una hija (I: II62. La oración a María).

II. La dama rica, bella y noble (I: II62-3. El amor a María).

I2. El clérigo que predicaba (II: II65. La grandeza de María).

I3. El sol, el fuego y el agua (II: II66. La oración a María).

I4. Las dos mujeres que oraban (II: II66. La grandeza de María).

I5. El mercader pobre (II: II66. La grandeza de María).

I6. Los hermanos mercaderes (III: II67-8. La perseverancia).

I7. El burgués rico y su hija (III: II68. La perseverancia).

I8. La mujer que amaba a su marido (III: II68. La lujuria).

I9. El buen religioso tentado (III: II68-9. El pecado).

2O. La mujer que disputó con un religioso (III: II69. La perseverancia).

2I. La mujer que amaba a su marido (III: II69-70. La castidad).

22. El debate entre un cristiano y un judío (IV: iI7o. La alabanza a María).

23. La mujer que compraba flores (IV: II7O-I. La alabanza a María).

24. Las dos mujeres de una ciudad (IV: II 7 I-2. El mal ejemplo).

25. La mujer que tenía un buen marido (IV: II72. La intención).

26. La mujer sabia y la mujer bella (V: II72. La alabanza a María).

27. El religioso que predicaba sobre la Trinidad (V: II72. La oración).

28. Las dos mujeres que rezaban a María (V: II74. La intención).

29. La mujer que contemplaba a María (V: II74. La intención).

3o. La nieve y el fuego (VI: II75. El amor de María).

3I. Las dos mujeres que alababan a María (VI: II75. La alabanza a María).

32. La mujer que tenía dos doncellas (VI: II75. La intención).

33. El cuerpo has sido creado para el amor (VI: II76. La justicia de Dios). 
34. Las dos mujeres que rezaban a María (VI: II76. La oración a María).

35. El santo ermitaño que había sido pecador (VI: II76-7. La intención).

36. La doncella virgen que amaba a María (VII: II78. La virginidad).

37. La mujer que amaba a su hijo enfermo (VII: II79. La lujuria).

38. Las dos mujeres que rezaban a María (VII: II79-8o. La oración a María).

39. El religioso que hacía sermones inútiles (VII: iI8o. El honramiento).

40. La mujer que quería saber y la que creía (VIII: ıI80-I. El amor a María).

4I. La mujer que peregrinó con la doncella (VIII: ıı8I. La primera y la segunda intención).

42. La mujer que alababa a María (VIII: II82. El amor a María).

43. La mujer que se confesaba (VIII: II82. El pecado).

44. La mujer a la que placía alabar a María (IX: ni83. Las obras).

45. La doncella virgen que quería hijos (IX: Ir83. La virginidad).

46. La mujer que ayunaba y la que hacía caridad (IX: Iı84. La gloria).

47. La mujer que pensaba en las penas del infierno (IX: II84. La gloria).

48. Las dos buenas mujeres (X: in85. La gracia).

49. Las hermanas casadas con mercaderes (X: II85. La oración a María).

50. Las dos mujeres que rezaban a María (X: in86. La oración a María).

$5^{\text {I. }} \quad$ La mujer casta que amaba a María (X: in86. La gloria).

52. El oro purificado por el fuego (XI: II87. El amor a María).

53. La nieve y el cristal (XI: II87. El resplandor de María).

54. El presbítero que amaba a María (XI: II87-8. El sacrificio).

55. Las piedras preciosas (XI: II88. La santidad).

56. La reina que amaba a María (XI: in88. La santidad).

57. La mujer que oraba a María (XI: II88-9. La oración a María).

$5^{8}$. El que yació con la hija y el que yació con la madre (XII: IIgo. La justicia).

59. El prelado lujurioso (XII: IIgo. La justicia).

6o. El pastor que perdió a sus ovejas por un lobo (XII: IIgo. La justicia).

6r. El cristiano, el sarraceno y el filósofo (XII: пrgi. La plegaría).

62. El rey sabio y justo (XII: IIgI. La justicia).

63. El máximo pecador (XIII: II92. El honramiento).

64. El caballero celoso (XIII: IIg2. La misericordia).

65. El rey lujurioso y el beguino (XIII: II92-3. La misericordia).

66. Las dos prostitutas (XIII: II94. El perdón).

67. El rey que tenía mala voluntad a otro rey (XIII: II94. El perdón).

68. Las dos mujeres que alababan a María (XIV: Ir95. La belleza de María).

69. El clérigo bello con mal coraje (XIV: II95-6. La belleza de María).

7o. El hijo enfermo del caballero (XIV: ıı66. La belleza de María).

7I. La mujer del burgués (XIV: ıı96-7. La belleza de María).

72. El clérigo mal acostumbrado y lujurioso (XV: Ir98. La virginidad).

73. La hija rica del burgués (XV: II98. La virginidad).

74. El marido lujurioso y celoso (XV: II99. La virginidad).

75. El hombre que se hizo religioso por castidad (XV: II99. La virginidad).

76. La mujer que rezó por un hijo bueno y bello (XVI: ı2Oo. El valor de María).

77. El rey sabio que tenía dos hijos (XVI: I2O2. El valor).

78. El hombre que quería ser famoso (XVI: I2O2. El valor).

79. El prelado y el príncipe que amaban a María (XVII: I2O3. El amor de María).

8o. La buena reina que amaba a María (XVII: ı2O3. La humildad). 
8I. El rey y la reina humildes (XVII: I2O3. La humildad).

82. El caballero de linaje que se casó con una burguesa (XVII: I2O4. La humildad).

83. Las dos mujeres que rezaban a María (XVIII: I2O5. La plegaria).

84. La mujer que compró una esclava (XVIII: I205. El servicio femenino).

85. Las dos mujeres que rezaban a María (XVIII: I206. El don a María).

86. La mujer que tenía una buena sirvienta (XVIII: ı206. El servicio femenino).

87. El rey que amaba a María y tenía dos hijos (XIX: г2O7. El honramiento a María).

88. El clérigo pobre de la iglesia rica (XIX: I2O7-8. El honramiento a María).

89. El príncipe que tenía dos hijos (XIX: ı209. El honramiento a María).

90. El escudero que amaba a su rey (XIX: I209-IO. El honramiento a María).

9I. El agua que va a parar al mar (XX: г2IO. La fe).

92. Los hombres que amaban la fe católica (XX: г2Ir. La fe).

93. Los dos hombres vanidosos (XX: i2II. La fe).

94. Los ríos que van al mar (XX: г2ı2. La pena).

95. Los dos santos que amaban la fe (XX: ı2ı2. La fe).

96. El califa de Bagdad (XX: г212-3. La fe).

97. La claridad del sol (XXI: I2I3. La visión de María).

98. Los dos frailes que amaban a María (XXI: I2I4. El amor a María).

99. El prelado que tomó sin derecho un castillo (XXI: I2I4. La esperanza).

IOo. Las dos mujeres que querían amar a María (XXI: ı2 I6. El amor a María).

IOI. El rey que tenía muchos enemigos (XXI: г2i6. La esperanza).

IO2. La reina y la mujer pobre que rezaban a María (XXII: I2I7. La oración a María).

Io3. El príncipe que fue a Tierra Santa (XXII: I2I7. La caballería).

IO4. Las dos mujeres continentes (XXII: I2I8. La continencia).

I05. La mujer casta sin temperancia (XXII: I2I8-9. La continencia).

Io6. El mercader que amaba a su hijo (XXIII: I22O. La paciencia).

IO7. La mujer casta y bien acostumbrada (XXIII: I22O-I. La paciencia).

Io8. El escudero que tenía mal señor (XXIII: I222. La paciencia).

Io9. El rey que celebró corte el día de María (XXIII: I222-3. La paciencia).

IIO. La mujer piadosa por María (XXIV: I224. La piedad).

III. La mujer devota de María (XXIV: i224. La piedad).

II2. El matrimonio preso por los sarracenos (XXIV: i225. La piedad).

II3. La mujer piadosa por María (XXIV: I225. La piedad).

II4. Las dos mujeres que pedían a María (XXV: I226. La consolación).

II5. El mercader que perdió todo lo que tenía (XXV: I226-7. La consolación).

II6. El hombre justo que tenía mujer e hijo (XXV: I228. La consolación).

II7. La buena mujer difamada por un loco (XXV: ı228. La consolación).

II8. Las dos hermanas que vivían de una viña (XXVI: ı229. La pobreza).

II9. El burgués heredero que se tenía que casar (XXVI: I229-3O. La pobreza).

I20. Las tres mujeres que rezaban a María (XXVI: ı230-I. La pobreza).

I2I. El pobre que fue al monasterio (XXVI: I23I. La pobreza).

I22. Las dos ricas que se convirtieron en pobres (XXVII: I232. La caridad).

I23. La rica que hacía caridad (XXVII: I232. La caridad).

I24. Las dos mujeres que hacían caridad (XXVII: I233. La caridad).

I25. El mal caballero que se arrepintió (XXVII: I233. La caridad).

I26. Los dos hombres sometidos (XXVIII: I235. La obediencia).

I27. El monje que obedecía al abad (XXVIII: I235-6. La obediencia). 
I28. El santo que buscaba la naturaleza de las cosas (XXIX: I237. La ayuda a María).

I29. El hombre que mató a su padre y se casó con su madre (XXIX: I237. La ayuda a María).

I30. El hombre que quería amar a Dios y a María (XXX: i239. La iluminación).

I3I. El hombre que subió a una montaña (XXX: I240. La justicia de Dios).

\section{IO Árbol de ciencia}

(III.23 - Arbre de ciència; Arbor scientiae [29/9/I295-I/4/I296 - Roma]. Total ejemplos: 383 . Carreras, Batllori, Carreras, Rubió i Balaguer I957-I96o, I, 547-IO46 [OE, I, 547-IO46]).

Título (libro, capítulo, sección: pág. Tema).

\section{Primera parte: árbol elemental}

I. La decocción de dos plantas (I,I,I7: 56I-2. La igualdad universal).

2. Las complexiones de la pimienta (I,III: $5_{53}$. Los cuatro elementos).

3. $\quad$ El hierro indivisible ( $\mathrm{I}, \mathrm{V}, 2: 567$. La cantidad de los elementos).

4. El hierro que quiere hacer un cuchillo (I,VII,I4: 573. La corrupción de la forma).

5. $\quad$ La espada hecha de hierro (I,VII,I5: 573. La privación de imaginación).

6. $\quad$ El agua en el pimienta (I,VII,I7: 573. El vacío de castidad).

7. La materia del agua y de la tierra (I,VII,I8: 573. La generalidad del árbol elemental).

8. $\quad$ La forma y la materia de la manzana (I,VII,38: 577. La tercioridad).

9. $\quad$ La materia del hierro (I,VII,4I: 578. La disposición).

IO. Las propiedades de la pimienta y del ruibarbo (I,VII,42: $57^{\circ}$. Las propiedades generales).

II. La burra que concibe un asno (I,VII,42: 578. Las propiedades apropiadas).

I2. El hombre que extrae hierro (I,VII,45: 579. La intención natural).

I3. El calor de la pimienta (I,VII,54: 58I. La inseparabilidad).

I4. El hombre que engorda y adelgaza (I,VII,54: 58I. La inseparabilidad).

I5. El hombre y el caballo (I,VII,57: 58I. La semejanza).

I6. El calor de la pimienta (I,VII,6I: 582. La transmutación).

I7. La materia del hierro (I,VII,6I: 582. La transmutación).

I8. La leche de la mujer (I,VII,73: 584. La nutrición).

I9. El aire y el fuego (I,VII,75: 584. El injerto).

2O. Las potencias vegetativa y elementativa (I, VII, $75: 5^{84}$. El injerto).

2I. El grano de la manzana (I,VII,78: 585. La atracción).

22. El olivo injertado en el oleastro (I,VII,78: 585. La atracción).

23. El clavo de hierro (I,VII,83: $5^{86}$. La vida).

24. El fuego y el sol (I,VII,89: 587. La concepción).

25. La planta en el invierno (I,VII,9O: 587-8. La dormición).

26. El hombre que imagina un placer (I,VII,9I: $5^{88}$. La vigilia).

27. Los frutos del manzano (I,VII,93: $5^{88}$. El gozo).

28. La sequedad del fuego (I,VII,94: 588. La ira).

29. El milano que se come al hijo de la gallina (I,VII,94: 588. La ira).

3o. El hombre enfermo (I,VII,94: 588. La ira).

3I. La entidad del manzano (I,VII,IOO: 59O. El ente).

32. La cabra que imagina un lobo (I,VII,IOO: 590 . El ente).

Segunda parte: árbolvegetal 
33. El olivo injertado en el oleastro (II,I: 590. Las dos naturalezas).

34. El tronco del manzano (II,II: 590. Las partes substanciales).

35. El manzano que quiere lluvia (II,III,I: 59I. La potencia apetitiva).

36. El caballo que busca a la yegua (II,III,I: 59r. La potencia apetitiva).

37. El hombre que gasta dineros (II,III,2: 59I. La potencia retentiva).

38. El hombre que come y bebe (II,III,3: 59I-2. La potencia digestiva).

39. El fuego señorea la pimienta y el ajo (II,VII: 594. Las cuatro especies de plantas).

\section{Tercera parte: árbol sensual}

40. El árbol injertado con tres especies (III: 594. Las cualidades discretas).

4I. Las raíces de los manzanos (III,I: 595. Las primeras formas).

42. El vidrio que contiene vino (III,I: 595. Las primeras formas).

43. La masa del oro (III,I: 595. Las primeras formas).

44. La potencia vegetativa del manzano (III,I: 596. El sentido común).

45. El olivo injertado en el oleastro (III,V: 6oo. Los accidentes).

46. La plata del dinero (III,V: 6oo. Los accidentes).

47. La cara del hombre en el espejo (III,VI: 6oo. Los sentidos).

48. La hierba que come el caballo (III,VII: 6oI. La corrupción).

49. La materia de los elementos (III,VII: 60I. La materia).

50. El cuerpo del caballo (III,VII: 602. La materia).

5I. La substancia del embrión (III,VII: 602. El vacío).

52. Las partes del caballo (III,VII: 602. La totalidad).

53. Los colores del caballo (III,VII: 602. La intensidad).

54. El caballo que no se mueve (III,VII: 6o2. El movimiento).

55. La carne blanda (III,VII: 602. La dureza).

56. El cuerpo del hombre (III,VII: 602. Las dimensiones).

57. Las potencias del caballo (III,VII: 602. Las potencias).

58. La forma del león (III,VII: 6o3. La disposición).

59. El calor natural del león (III,VII: 6o3. La inseparabilidad).

6o. La elementalidad del león (III,VII: 604. La semejanza).

6I. La natura del fuego (III,VII: 604. La naturaleza).

62. El león que come un carnero (III,VII: 604. La naturaleza).

63. El león que reluce por el fuego (III,VII: 604. La luminosidad).

64. Los puntos y las líneas del león (III,VII: 604. La superficie).

65. Los seis atajos del león (III,VII: 604. La figura).

66. La nutrición del león (III,VII: 605. La impresión).

67. El calor del fuego injerta el aire (III,VII: 605. La perseidad).

68. La naturaleza del león (III,VII: 605. La individualidad).

69. Las necesidades del león (III,VII: 605-6. La contingencia).

7O. El león que toca el agua con la lengua (III,VII: 6o6. El tacto).

7I. El sueño del león (III,VII: 6o7. El sueño y la vigilia).

72. La naturaleza elemental del león (III,VII: 6o7. El gozo).

73. La salud del león (III,VII: 607. La enfermedad).

74. El león que caza (III,VII: 6o7. La industria).

75. La substancia elemental del león (III,VII: 6o7. La esencia). 
76. La planta en el espejo (IV: 6o8. La semejanza en figura).

77. La cera del sello (IV,I: 6o8. La semejanza).

78. El sabor de la manzana (IV,I: 6o8. La semejanza).

79. La figura de los elementos (IV,I: 6o8. La semejanza).

8o. El fuego que calienta el agua (IV,II: 6og. La semejanza).

8I. La planta en el espejo (IV,II: 6o9. La semejanza).

82. El fuego y el agua (IV,III,I: 6o9-Io. La imaginación).

83. Los apetitos del hombre (IV,III,2: 6Io. La semejanza).

84. El hombre que escucha notas musicales (IV,III,4: 6Io. La semejanza).

85. El hombre que imagina dulce y amargo (IV,III,6: 6Ir. La semejanza).

86. El hombre que toca cosas frías (IV,III,7: 6II. La semejanza).

87. El fuego que calienta el agua (IV,III,8: 6II. La semejanza).

88. La masa de los elementos compuestos (IV,IV: 6I2. La semejanza).

89. El manzano que nace de la tierra (IV,IV: 6I2. La semejanza).

90. El sabor del vino (IV,V,I: 6I2-3. La semejanza).

9r. Las letras a cera del sello (IV,V,2: 6rz. La semejanza).

92. El vestido blanco (IV, $\mathrm{V}, 3: 6 \mathrm{I3}$. La semejanza).

93. La letra del sello (IV,V,3: 6r3. La semejanza).

94. La situación del hombre (IV,V,6: 6I4. La semejanza).

95. La planta que crece (IV,V,7: 6I4. La semejanza).

96. El gusto de la manzana (IV,V,7: 6I4. La semejanza).

97. La botella de vino (IV,V,8: 6I5. La semejanza).

98. El hombre que imagina un sabor (IV,VI: 6I5. La semejanza).

\section{Quinta parte: árbol humanal}

99. El caballero que defiende al rey (V,I: 6I6. La finalidad).

Ioo. El hombre acalorado (V,II: 6I6. El calor).

IOI. El hombre contra sus componentes (V,III,I: 6rg. La contrariedad).

IO2. El cuerpo conjuntado (V,III,2: 62O. El entendimiento).

IO3. Los hombres flemáticos (V,III,2: 62O. El entendimiento).

IO4. El hombre que se entiende a él mismo (V,III,2: 62I. La especie).

IO5. El clavo clavado y desclavado (V,III,2: 622. El entendimiento).

Io6. Los ojos que ven los colores (V,III,2: 623. El entendimiento).

IO7. Las condiciones del agua (V,III,2: 624. El entendimiento).

Io8. La zorra que caza (V,III,2: 624. El entendimiento).

Io9. Las líneas al punto (V,III,3: 625. La voluntad).

IIO. La naturaleza del fuego (V,III,3: 625. La voluntad).

III. El hombre que tiene frío (V,III,3: 625. La voluntad).

II2. La nave que mueve a los marineros (V,III,3: 625. La voluntad).

II3. Los ojos que ven libremente (V,III,3: 626. La voluntad).

II4. El hierro que hace un bello cuchillo $(\mathrm{V}, \mathrm{V}, 5: 629$. El hecho de obrar).

II5. Los que hacen pimienta y trapos ( $\mathrm{V}, \mathrm{V}, 5: 63$ o. La prosperidad).

II6. Las piedras que forman la torre $(\mathrm{V}, \mathrm{V}, 5: 63$ I. La aritmética).

II7. La salud es el principio de la medicina ( $\mathrm{V}, \mathrm{V}, 5: 63$ I. Las cantidades).

II8. El hierro que saca un clavo $(\mathrm{V}, \mathrm{V}, 5$ : 63. La música).

II9. El fuego que calienta (V,V,7:634. El tiempo).

I2O. El entendimiento que imagina un cuervo (V,V,7: 634. El tiempo). 
I2I. El sello de cera ( $\mathrm{V}, \mathrm{V}, 7: 634$. El tiempo).

I22. El cerebro que enjuicia ( $, \mathrm{V}, 8: 634$. El lugar).

I23. El árbol que se mueve con la nave (V,V,0: 634. El lugar).

\section{Sexta parte: a) árbolmoral (virtudes)}

I24. El hombre que usa bien las cosas (VI,I: 636. La bondad).

I25. El hombre que usa bien los vegetales (VI,I: 636. La bondad).

I26. El hombre que escucha bien (VI,I: 636. La bondad).

I27. El hombre que imagina buenas obras (VI,I: 636. La bondad).

I28. La bestia obstinada (VI,I: 636. La virtud).

I29. La mala mujer (VI,I: 636. La virtud).

I3O. El olivo injertado en el oleastro (VI,III,2: 638. La prudencia).

I3I. Los cuatro religiosos que se ayudan (VI,III,4: 639. Las virtudes cardinales).

I32. El olivo injertado en el oleastro (VI,III,5: 639. La fe).

I33. El frío recuerda el calor (VI,III,6: 640. La bondad de Dios).

I34. Los hombres ricos y los pobres (VI,III,7: 640. La caridad).

I35. El hombre tentado (VI,III,I4: 642. La fortaleza).

I36. El rey humilde (VI,III,2O: 643. La misericordia).

I37. El hombre con esperanza (VI,III,2I: 643. La justicia de Dios).

I38. El hombre injuriado (VI,III,22: 643. La caridad).

I39. Los hombres borrachos (VI,III,23: 643. La temperancia).

I4O. La cualidad del fuego (VI,V,2: 648. La prudencia).

I4I. El fuego que deshace la cera (VI,V,4: 648. La temperancia).

I42. El cuerpo de figura circular (VI,V,6: 648. La esperanza).

I43. La luz de la lámpara de aceite (VI,VI,3: 650. La fortaleza).

\section{Sexta parte: b) árbol moral (vicios)}

I44. El loco que no entendía (VI,I: 65. La privación).

I45. El olivo injertado en el oleastro (VI,I: 652. Los malos hábitos).

I46. El hombre enfermo (VI,III,I: 653. La gula).

I47. El fuego que calienta las plantas (VI,III,6: 654. La envidia).

I48. El rico interrumpido (VI,III,I5: 656. La avaricia).

I49. Los mercaderes avaros (VI,III,I6: 656. La avaricia).

I5O. El hombre engañado (VI,III,29: 658. El homicidio).

I5I. El punto y la línea (VI,V,8: 662. El pecado).

I52. El agua a la fragua (VI,VII: 663. La gloria de Dios).

I53. El príncipe y el hombre injurioso (VI,VII: 663. La gloria de Dios).

\section{Séptima parte: árbol imperial}

I54. El veneno mezclado con triaca (VII,I: 664. La perversión).

I55. El martillo del herrero (VII,II: 664. El buen príncipe).

I56. Los césares de Roma (VII,III,I: 665. La utilidad).

I57. Los lobos y las ovejas (VII,III,4: 665. El mal consejo).

I58. Las herramientas del herrero (VII,III,7: 666. Los abogados).

I59. Las ovejas confiadas al pastor (VII,IV,3: 668. El temor).

I60. El fuego que va contra el agua (VII,IV,7: 669. La libertad).

I6I. La piedra que cae (VII,IV,7: 669. La libertad). 
I62. El caballero que vendió su caballo (VII,V,I-0: 670-2. Los nueve accidentes).

I63. Las plantas necesitan el sol (VII,VII: 673. El mal príncipe).

I64. El calor del fuego (VII,VII: 673. El mal príncipe).

I65. El calor del fuego (VII,VII: 673-4. El mal príncipe).

\section{Octava parte: árbolapostolical}

I66. Las ovejas y el pastor (VIII,I: 674. La justicia del papa).

I67. La luna, el sol y las plantas (VIII,I: 675. La fe del papa).

I68. El pastor y las ovejas (VIII,I: 675. La fe del papa).

I69. El fuego que tiende al aire (VIII,I: 675. La fe del papa).

I7O. El sol es más grande que la luna (VIII,II: 675-6. El tronco del árbol apostolical).

I7I. La substancia atrae las partes (VIII,II: 676. El tronco del árbol apostolical).

I72. Los maestros de ciencias (VIII,IV,4: 679. La imaginación).

I73. El herrero ama los dineros del cuchillo (VIII,IV,5: 679. El poder sensual).

I74. El avaro que esconde el dinero en cajas (VIII,IV,5: 679. El poder sensual).

I75. El olivo injertado en el oleastro (VIII,V,I,I: 68o. El bautismo).

I76. El martillo del herrero (VIII,V,I,I: 680. El poder divino).

I77. Las letras del sello de cera (VIII,V,I,3: 68ı. El matrimonio).

I78. El arte de herrería (VIII,V,I,4: 68I. La eucaristía).

I79. El aire es medio del fuego y del agua (VIII,V,I,4: 682. La pasión).

I80. El martillo y el clavo (VIII,V,I,5: 683. La ordenación).

I8I. El fuego que se mueve en la pimienta (VIII,V,I,6: 683. La penitencia).

I82. Los ojos del hombre (VIII,V,I,7: 684. La restauración).

I83. El sol que ilumina la tierra (VIII,V,I, 7: 684. Los sacramentos).

I84. El herrero que fabrica un clavo (VIII,V,II,3: 684. La relación).

I85. El vino dentro de la botella (VIII,V,II,8: 687. El lugar).

I86. Las tenazas y el martillo (VIII,VI: 689. Los comienzos y los medios).

I87. El herrero que trabaja el hierro (VIII,VI,2: 69I. La unidad).

I88. El martillo y el pan (VIII,VI,2: 69I. La existencia y la agencia).

I89. El gran reino del buen rey (VIII,VI,4: 693. El alma).

I9o. El olivo injertado en el oleastro (VIII,VI,6: 697. La razón y los sentidos).

I9I. La pimienta y el ajo (VIII,VI,6: 697. El pecado original).

I92. La calor natural de el hombre (VIII,VI,6: 698. El mal).

I93. El herrero que fabrica cuchillos sin pecado (VIII,VI,6: 698. El mal).

I94. La doncella nutrida con veneno o triaca (VIII,VI,6: 698. El pecado original).

I95. El fuego de la pimienta (VIII,VI,6: 699. El pecado original).

I96. La batalla del rey (VIII,VI,6: 699. El pecado original).

I97. La lámpara de aceite (VIII,VI,6: 699. El pecado original).

I98. La calor del fuego y del aire (VIII,VI,6: 699. El pecado original).

I99. El fuego injertado en el aire (VIII,VI,6: 7O0. El pecado original).

200. El hombre injusto (VIII,VI,6: 700. El pecado original).

2OI. El hombre desamado (VIII,VI,6: 7OI. El pecado original).

202. El que no orina ante la gente (VIII,VI,7: 7O2. La imaginación).

203. La saeta en el fuego (VIII,VI,7: 7O2. El alma).

204. La flor blanca (VIII,VI,7: 7O2. El alma).

205. El fuego que calienta el aire (VIII,VI,7: 7O3-4. La gloria).

206. El pastor que ama a las ovejas (VIII,VI,7,3: 7O7. Jesucristo). 
2O7. El olivo injertado en el oleastro (VIII,VI,7,6: 709. Jesucristo).

208. El calor del fuego (VIII,VI,7,7: 7IO. El juicio final).

\section{Novena parte: árbol celestial}

209. El movimiento del sol (IX,II: 7I2. La bondad).

2IO. La piedra que cae (IX,II: 7I2. El firmamento).

2II. El fuego que escalfa (IX,III: 7I5. Los signos).

2I2. El caballo que corre (IX,III: 7 I5. Los signos).

2I3. La ballesta fatigada (IX,III: 7 I5. Los signos).

2I4. El sol que seca (IX,III: 7I5. Los signos).

2I5. Las letras impresas en cera (IX,III: 7I5. Los signos).

2т6. Las luces y las voces (IX,IV: 7 16 . Los planetas).

2I7. Las gotas de agua del mar (IX,IV: 7I6. Los planetas).

2I8. La pimienta y el caballo (IX,IV: 7I7. Los planetas).

2I9. Las letras del sello (IX,IV: 7I7. Los planetas).

220. La figura de hierro (IX,V,I: 7I7. La cantidad).

22I. La carne del dedo (IX, V,I: 7I7-8. La cantidad).

222. El fuego y el aire (IX,V,2: 7 I8. La luna y el sol).

223. El calor del fuego (IX, V,2: 7 I8. La luz del sol).

224. La luz del fuego (IX, V,5: 7I9. El sol).

225. La mano que mueve la pluma (IX,V,5: 7I9. El hábito).

226. Los momentos del día (IX,V,7: 7I9. El tiempo).

227. El hombre pecador (IX,V,7: 7I9-2O. El tiempo).

228. El fuego que calienta e ilumina (IX, $\mathrm{V}, 7: 720$. El tiempo).

229. El movimiento del fuego y del aire (IX,VI: 720. Los planetas).

230. El león y la leona (IX,VI: 720. Los planetas).

23I. La nota de la viola (IX, VI: 720. Los planetas).

232. La nave que se hunde en el mar (IX,VII: 72I. El pecado).

Décima parte: árbol angelical

233. El rey injurioso (X,I: 72I. La contrariedad).

234. La cera del sello (X,III: 723. La especie).

235. El sol que ilumina (X,IV: 724. El entendimiento).

236. El cuchillo que corta la carne (X,IV: 724. El entendimiento).

237. El fuego que calienta más que la pimienta (X,IV: 724. El entendimiento de los ángeles).

238. El hombre avaro (X,IV: 724. El entendimiento de los ángeles).

239. El hombre justo (X,VI: 728. La esencia).

240. El sol atrae el calor (X,VI: 729. La bondad de Dios).

24I. El vaso en el mar (X,VII: 729. La gloria de Dios).

242. La habitación llena de aire (X,VII: 729-30. La gloria de Dios).

\section{Decimoprimera parte: árboleviternal}

243. El movimiento del sol (XI,V,2: 733. El arcángel Miguel).

244. La piedra que cae (XI,V,2: 733. Lucifer).

245. El fuego que calienta (XI,V,4: 733-4. El cuerpo glorificado de san Pedro).

246. El fuego que calienta (XI, $, 4,4: 734$. El cuerpo de Judas Iscariote).

247. El pez que se mueve en el agua (XI,V,7: 735. El cuerpo glorificado). 
248. El pez en el mar (XI,V,7: 735. El cuerpo atormentado).

249. El gusto del enfermo (XI,VI,2: 737. El amor eterno).

250. La llama del fuego (XI,VII,I: 738-9. La gloria).

\section{Decimosegunda parte: árbolmaternal}

25I. El buen pastor (XII,IV,4: 743. El poder de María).

252. El hombre que se calienta al fuego (XII,IV,5: 743. El poder de María).

253. Los pollitos bajo las alas de la gallina (XII,IV,8: 744. La esperanza de María).

254. La manzana y la rosa (XII,VII: 745. El fruto de María).

\section{Decimotercera parte: árbol de Jesucristo}

255. El olivo injertado en el oleastro (XIII,I: 746. La bondad de Jesús).

256. El dinero de oro y plata (XIII,II: 746. Las dos naturalezas de Jesús).

257. Los cuatro elementos de la manzana (XIII,II: 747. Las dos naturalezas de Jesús).

258. La substancia blanca (XIII,III: 747-8. La humanidad de Jesús).

259. El fuego y la sequedad de la tierra (XIII,V,2: 749. Las cualidades substanciales).

26o. La materia del pan (XIII,V,3: 749. La forma y la materia).

26r. El agua y el calor del fuego (XIII,V,4: 75o. La humanidad de Jesús).

262. La ciencia del lógico (XIII,V,5: 750. Las dos naturalezas de Jesús).

263. El agua calentada en la olla (XIII,V,7: 75I. La eternidad).

264. El poder del fuego (XIII,VI,3: 752. La bondad).

265. El fuego y el aire (XIII,VI,65: 76r. La concordancia).

266. El caballo y el caballero (XIII,VI,I34: 772. La finalidad).

267. El huevo de la gallina (XIII,VI,I37: 772. La igualdad).

\section{Decimocuarta parte: árbol divinal}

268. El herrero que hace un clavo de hierro (XIV,III,3: 778-9. La obra artificial).

269. Las dos piedras que dan fuego (XIV,IV,2: 784. La espiración).

270. El viento, el trueno y los relámpagos (XIV,IV,3: 784. El Espíritu Santo).

27I. El herrero que trabaja con fuego (XIV,V,7: 788. La eternidad).

272. El pecador que ha pecado mortalmente (XIV,V,7: 788. La misericordia).

\section{Decimoquinta parte: árbol ejemplifical}

273. El calor del fuego en el agua (XV,I: 799-804. La moralidad).

274. Las dos enfermedades del aire (XV,I: 799. La contrariedad).

275. El rey que amaba a un caballero (XV,I: 80I-802. La misericordia).

276. El juez de los dos caballeros (XV,I: 802. El juicio).

277. El caballero pobre y el campesino rico (XV,I: 802. El engaño).

278. El buen ermitaño y el ángel (XV,I: 803. La concordancia).

279. La aguja del sastre (XV,I: 8o3. La privación).

280. El rico que tenía dos hijos (XV,I: 803-4. La caridad).

28I. El hijo del hombre asesinado (XV,I: 804. La caridad).

282. El encuentro de los cuatro elementos (XV,III,I: 8og. Los elementos).

283. La mujer que amaba a su marido lujurioso (XV,III,I: 8og. La diferencia).

284. La mujer y el hijo del caballero (XV,III,I: 8og. La diferencia).

285. La apetitiva, la digestiva, la retentiva y la expulsiva (XV,III,I: 8og. El ramo vegetal).

286. El combate de la noche y de la muerte (XV,III,2: 8o9-Io. La temperancia). 
287. La rata y el gato que jugaban con una pluma (XV,III,3: 8Io. El ramo sensual).

288. El burgués que mató a un caballero (XV,III,3: 8Io. La amistad).

289. La romería del caballo y del león (XV,III,3: 8Io. El perdón).

290. Los dos corderos que mataron un lobo (XV,III,4: 8IO-I. El ramo de la imaginación).

29I. El león que mató al hijo del pastor (XV,III,4: 8Io. La caridad).

292. El lebrel del caballero (XV,III,4: 8IO-I. La ira).

293. El consejo del león a su pueblo y al hombre (XV,III,5: 8II. El ramo corporal).

294. Las potencias del alma subieron al cielo (XV,III,6: 8II-2. El ramo espiritual).

295. La disputa del judío, el cristiano y el sarraceno (XV,III,6: 8ı2. La argumentación).

296. El asno del prohombre (XV,III,6: 8I2. La concordancia).

297. El mensaje del rey al emperador (XV,III,7: 8I2. El ramo moral).

298. El barón lujurioso en la corte del rey sabio (XV,III,8: 8I2-3. El ramo imperial).

299. La lujuriosa mujer del caballero (XV,III,8: 8ı2-3. La alabanza y la vergüenza).

300. El labrador que clamaba al cielo (XV,III,8: 8I3. La diferencia).

3OI. Los simios que querían hacer fuego (XV,III,8: 8I3. La experiencia).

302. El peregrinaje de Honramiento y Sabiduría (XV,III,9: 8I3-4. El ramo apostolical).

303. El lebrel que quiso ayudar a su hermano (XV,III,9: 8I3. El servicio).

304. El rey y el astrólogo (XV,III,IO: 8I4. El ramo celestial).

305. El rico avaro y los tres pobres (XV,III,II: 8I4-5. El ramo angelical).

306. Los arcángeles, Dios y Lucifer (XV,III,II: 8I4-5. La compañía).

307. La esperanza de Lucifer en Dios (XV,III,I2: 8I5. El ramo eviterno).

308. El rey justo y el mal caballero (XV,III,I2: 8I5. La desesperanza).

309. El pecador vanidoso (XV,III,I2: 8I5. La pena eterna).

3IO. Las dignidades divinas que oraban (XV,III,I3: 8I5-6. El ramo maternal).

3II. El mundo pregunta a Dios por qué lo creó (XV,III,I3: 8I6. La esperanza).

3I2. La inglesa devota de María y su hijo (XV,III,I3: 8ı6. La esperanza).

3I3. El ermitaño iletrado que disputó con un judío (XV,III,I4: 8I6-7. El ramo cristiano).

3I4. La obra de Sabiduría, Voluntad y Poder (XV,III,I4: 8I7. La Encarnación).

3I5. Las nobles mujeres ociosas en la iglesia (XV,III,I5: 8I7. El ramo divino).

$3^{\mathrm{I} 6 .}$ El debate entre la pimienta y la calabaza (XV,IV,I: 8I7-8. El ramo divino).

3I\%. Los lobos y las ovejas (XV,IV,I: 8I8. La ociosidad).

3I8. Generación, corrupción, privación y renovación (XV,IV,2: 8I8. El ramo divino).

3I9. La bella mujer que se maquillaba (XV,IV,2: 8I8. La fortuna).

320. Los ojos que fueron de peregrinaje (XV,IV,3: 8I8-9. El ramo sensual).

32I. El encuentro de la Vista y el Gusto (XV,IV,4: 8I8-9. El ramo de la imaginación).

322. El hijo del mercader rico (XV,IV,4: 8I9. La avaricia).

323. El príncipe avaro (XV,IV,4: 8I9. La avaricia).

324. La oración que subió al cielo (XV,IV,5: 819-20. El ramo humano).

325. El caballero rico y vanaglorioso (XV,IV,5: 8I9-2O. La justicia).

326. El comienzo y el fin (XV,IV,5: 82O. La salvación).

327. La romería de Potencia, Objeto y Acto (XV,IV,6: 82O-I. El ramo moral).

328. El hombre que trabajó para honrar a Dios (XV,IV,6: 82O-I. El honramiento de Dios).

329. El consejo del rey coronado (XV,IV,7: 82I-3. El ramo imperial).

33o. Voluntad y Entendimiento en un vergel (XV,IV,8: 823. El ramo apostólico).

33I. El hombre hambriento (XV,IV,8: 823. La imaginación).

332. Saturno y Júpiter rogaron al Sol que hablase con Dios (XV,IV,9: 823-4. El ramo celestial).

333. El obispo necio y el obispo sabio (XV,IV,IO: 824. El ramo angelical). 
334. El prelado en pecado mortal (XV,IV,II: 824. El ramo eviterno).

335. La Voluntad se encuentra con la Virtudes (XV,IV,I2: 824-5. El ramo maternal).

336. El príncipe poderoso (XV,IV,I2: 825. El amor a María).

337. El pecado que imaginaba sus pecados (XV,IV,I3: 825. El ramo cristiano).

338. El encuentro de Dar y Tomar en Bondad (XV,IV,I4: 825-6. El ramo divino).

339. El encuentro de Sabiduría y de Justicia en Hombre (XV,V,I: 826. La cantidad elemental).

340. La flor y el hombre que orinaba en el almendro ( $\mathrm{XV}, \mathrm{V}, 2$ : 826 . La calidad vegetal).

34I. La bella manzana y el puerco (XV,V,2: 826. La belleza y la suciedad).

342. Las cualidades elementales en las cerezas (XV,V,2: 826. La belleza y la suciedad).

343. La relación de la potencia, el objeto y el acto ( $\mathrm{XV}, \mathrm{V}, 3$ : 826-7. La relación sensual).

344. El pecador que cazó una liebre ( $\mathrm{XV}, \mathrm{V}, 4$ : 827. La acción y la pasión).

345. El encuentro de Belleza y Bondad en una mujer (XV,V,5: 827-8. El hábito humano).

346. La lámpara que quemaba todas las noches (XV,V,5: 828. La bondad y la maldad).

347. El diálogo entre el cuerpo y el alma del rey ostentoso (XV,V,6: 828. La moral).

348. La hija única del rey ( $\mathrm{XV}, \mathrm{V}, 7: 828$. El tiempo imperial).

349. La llamada de Poder, Sabiduría y Voluntad a Igualdad (XV,V,8: 828-9. El lugar apostólico).

350. La romería de los cuatro elementos ( $\mathrm{XV}, \mathrm{V}, 8:$ : 829. El lugar sin continente ni contenido).

35. El Círculo, el Triangulo y el Cuadrángulo (XV,V,9: 829. La cantidad celestial).

352. Un ermitaño encontró al demonio en una fuente (XV,V,IO: 829-30. La cualidad angelical).

353. El cuervo que preguntó a los elementos de qué vivían (XV,V,Io: 829-3o. El mal y la pena).

354. El paraíso y el infierno que se escarnecían (XV,V,Ir: 83o. La relación eviterno).

355. El hijo del rey alimentado por una loba (XV,V,II: 83o. La gloria).

356. El encuentro de Acción y Pasión en Jesús (XV,V,I2: 830. La acción y la pasión maternal).

357. El encuentro de Necesidad y Contingencia en Diferencia (XV,V,I3: 83O-I. El hábito).

358. El hombre que pensaba en Dios antes de la creación (XV,V,I4: 83I. El lugar divino).

359. El debate entre un cristiano y un sarraceno (XV,V,I4: 83. El lugar de Dios).

36o. El debate de las piedras del anillo del rey (XV,VII,r: 835-6. El fruto elemental).

36r. El debate de la espada y el escudo del rey (XV,VII,r: 835-6. El fruto elemental).

362 . El debate de las potencias de la manzana (XV,VII,2: 836 . El fruto vegetal).

363. El pan que hicieron la harina, el agua y el horno (XV,VII,2: 836 . El juicio).

364. El molinero que nutría un puerco con trigo (XV,VII,3: $8_{3} 6$. El fruto sensual).

365. El debate del Pasado y del Futuro en la Imaginación (XV,VII,4: 836-7. El fruto).

366. El debate del Cuerpo y el Alma (XV,VII,5: 837. El fruto humano).

367 . El obispo que quería ser arzobispo (XV,VII,5: 837. El fruto humano).

368. El debate entre Virtud y Mérito (XV,VII,5: 837. El fruto moral).

369. El halcón del rey que tomaba grullas (XV,VII,6: 836-7. El fruto de la imaginación).

37O. El debate de la Corona y la Paz (XV,VII,7: 837-8. El fruto imperial).

37I. El bello caballo del rey (XV,VII,7: 838. La guerra y la paz).

372. El debate de Honramiento y de Salvación (XV,VII,8: 838. El fruto apostólico).

373. El debate del sol y del rey (XV,VII,9: 838-9. El fruto celestial).

374. El procurador que gobernaba la ciudad por el rey (XV,VII,9: 838-9. El juicio).

375. El alquimista que quería hacer plata (XV,VII,9: 839. El honramiento).

376. El ermitaño, el ángel y el demonio (XV,VII,IO: 839. El fruto angélico).

377. La viña que encontraron el latino y el sarraceno (XV,VII,IO: 839. El contraste).

378. El hombre que sentía predicar del paraíso e infierno (XV,VII,II: 839-4O. El fruto eviterno).

379. El monje que alababa a la Virgen (XV,VII,I2: 840. El fruto maternal).

380. El Entendimiento quería entender los artículos de la fe (XV,VII,I2: 840. La razón y la fe). 
38I. El encuentro de Voluntad y Entendimiento (XV,VII,I3: 840. El fruto cristiano).

382. El rey que pidió un préstamo a un rey avaro (XV,VII,I3: 84I. La voluntad y la razón).

383. El maestro en teología que cabalgaba (XV,VII,I4: 84I-2. El fruto divino).

\section{II Arbol de filosofía de amor}

(III.32 - Arbre de filosofia d'amor [ıо/ı298 - París]. Total ejemplos: 8. Carreras, Batllori, Carreras, Rubió i Balaguer I957-I960, 2,II-84 [OE, 2,II-84]).

Título (parte, capítulo, versículo: pág. Tema).

I. La belleza y el resplandor del sol (IV,2,2: 47. La virtud divina).

2. La belleza de la mar (IV,2,3: 47. La belleza de las cosas).

3. $\quad$ El árbol cargado de hojas y flores (IV,2,4: 47. El amor de Dios).

4. El mal caballero que tenía un bello castillo (IV,2,5:47. El amor de Dios).

5. $\quad$ La belleza de la mesa (IV,2,6:47. La belleza y la moral).

6. El bello libro del falso juez (IV,2,7: 47-8. Las palabras agradables a Dios).

7. La Enfermedad, la Muerte y el sepelio del amigo (V,I-IO: $55^{-65}$. El amor a Dios).

8. $\quad$ El sol siempre luce (VII,3,I7: 78. La gloria de Dios).

\section{I2 Libro del es de Dios}

(III.45 - Liber de est Dei; Llibre de l’és de Déu [9/ızoo - Mallorca]. Total ejemplos: I. Amengual 20IO, 33-62 [NEORL, 9, 33-62]).

Título (distinción, capítulo: pág. Tema).

I. $\quad$ El amor del amador (V,I: 52. El es de Dios).

\section{I3 Libro de conocimiento de Dios}

(III.46 - Llibre de coneixença de Déu [Iо/I300 - Mallorca]. Total ejemplos: 2. Amengual 2oro, 63II] [NEORL, 9, 63-II?]).

Título (distinción, capítulo: pág. Tema).

I. $\quad$ El hombre mortal (I,I: 67. La existencia de Dios).

2. El martillo y el clavo (XX,3: Io6. Las cualidades de Dios).

\section{I4 Libro de Dios}

(III.48 - Llibre de Déu [ı2/I3Oo - Mallorca]. Total ejemplos: ı3. Amengual 2OIO, II9-I83 [NEORL, 9, ІІ9-I83]).

Título (distinción, capítulo, parte: pág. Tema).

I. $\quad$ El hierro y el martillo (I,I,ix: I28-9. La gloria de Dios). 
2. El hijo Ramón y su padre (I,I,X: I29. La necesidad de Dios).

3. La unidad del fuego (I,2,i: I29. La unidad de Dios).

4. El herrero y la herrería (I,4,i: I36. La esencia de Dios).

5. $\quad$ El maestro y su obra (I,, , v: I 45-6. La creación del mundo).

6. El hierro y el clavo (I,7,v: I46. La creación del mundo).

7. $\quad$ La bondad de Martín (I,9,ii: 5 5. La bondad de Dios).

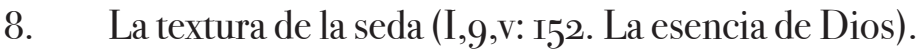

9. El hacedor y la factura (II,I,X: I6o. Las criaturas de Dios).

IO. El sol y el cielo (II,I,X: I6o. Las criaturas de Dios).

II. Los granos de mijo y de pimienta (II,I,X: I6o. Las criaturas de Dios).

I2. Los elementos del pan (II,4,iiii: ı66. La Encarnación).

\subsection{Retórica nueva}

(III.5O - Rhetorica nova [9/ıзоI - Chipre]. Total ejemplos: 39. Batalla, Cabré, Ortín 2006 [TORL, I]).

\section{Título (capítulo: pág. Tema).}

I. $\quad$ El militar y Alejandro (I5: IO4-7. Pedir algo).

2. El caballero que confió a su mujer (I6: Io6-9. El rechazo).

3. Las propiedades de las criaturas (39: 124-7. La Trinidad).

4. La naturaleza humana de Jesucristo (40: I26-7. La creación).

5. Jesucristo liberó a los hombres (4I: I26-7. La renuncia al mundo).

6. La natura de los ángeles (42: I28-9. La obligación de servir a Dios).

7. $\quad$ El servicio de Dios a los hombres (43: I28-9. La ofensa de los pecadores a Dios).

8. El obispo hipócrita (44: 128-9. Los hipócritas).

9. La brillantez del sol (45: I3O-I. La gracia y la bendición de Dios).

IO. La fortaleza del león (46: I3O-I. La guerra).

II. La vista del águila (47: 130-3. Los santos).

I2. El pez en el mar (48: I32-3. El servicio paciente a Dios).

I3. La vieja garza (49: I32-3. Los malos viejos)

I4. La zorra y el león (50: I34-7. Los príncipes y prelados).

I5. Las dos monas (5I: I36-7. Los obstinados).

I6. La belleza de los hombres (52: I38-9. Los pecadores y viciosos).

I7. El calor del fuego (53: I38-9. Los hipócritas).

I8. Los árboles con frutos (54: I38-9. Los entregados a los placeres).

I9. Los árboles con frutos (55: 138-9. Los entregados a los placeres).

20. La belleza de la rosa (56: I $40-$ I. Los que aman a Dios).

2I. $\quad$ El lirio (57: I4O-I. Los soberbios).

22. La influencia del sol en las flores (58: I4O-I. Los soberbios).

23. El color del oro (59: $\mathrm{I}_{4} \mathrm{O}-3$. Los avariciosos).

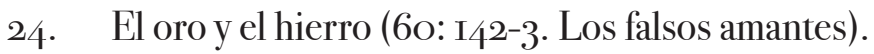

25. La nobleza de las horcas (6r: I42-3. Los reyes injustos).

26. La esmeralda y el imán (62: I42-3. Los falsos amantes).

27. La bondad del rey (65: I 44-5. El buen gobierno).

28. El emperador romano (I5O: I7O-I. La justicia de los reyes). 
29. El caballo del rey (I83: 194-7. La justicia de los reyes).

30. La mujer del caballero (I9I: 204-7. La caridad).

3I. El hijo soberbio (I92: 206-7. La caridad).

32. El caballero airado (193: 206-7. La caridad).

33. La viuda noble (I94: 208-9. La caridad).

34. El archidiácono del obispo (I95: 208-II. La caridad).

35. El arca con mil talentos (I96: 2IO-I. La caridad).

36. El hijo del mercader (197: 212-3. Los desolados).

37. El rey y el sacerdote (I98: 2I2-5. Los que reprenden).

38. La sirvienta caritativa (I99: 2I 4-5. Los avariciosos).

39. La mujer pobre (200: 2I5-7. La fuerza de las palabras).

\section{I6 Del nacimiento de Jesús infante}

(IV.34 - Liber natalis pueri parvuli Christi Jesu [I/I3II - París]. Total ejemplos: 3. Carreras, Batllori, Carreras, Rubió i Balaguer I957-I960, 2, I277-I295 [OE, 2, I277-I295]).

Título (capítulo:pág. Tema).

I. $\quad$ Los rayos del sol cuando sale (XV: I282. La Trinidad).

2. $\quad$ El intelecto de los hombres (XX: I288. El amor de Dios).

3. El hombre que conoce a Dios (XXV: r292. La finalidad de los ángeles).

\section{I7 Elfantástico}

(IV.49 - Liber disputationis Petri et Raimundi [ı/I3II - París-Vienne]. Total ejemplos: 2. Badia $2008[T O R L, 2])$.

Título (libro, pág. Tema).

I. $\quad$ El aceite que flota en el agua (I: I3I. La fe y el entendimiento).

2. Las dos espadas de la Iglesia (V: I69-I7r. El orden eclesiástico).

\section{I8 Libro de virtudes y de pecados}

(IV.65 - Liber de virtutibus et peccatis sive Ars major praedicationis [I/I3I3 - Mallorca]. Total ejemplos: 2Or. Domínguez r99o [NEORL, I]).

Título (capítulo:pág. Tema).

I. La mujer vendedora (I: I2. La justicia y la injuria).

2. Los bienes terrenales y naturales (I: I2. La justicia y la injuria).

3. La mujer bella y buena (I: I2-3. La justicia y la injuria).

4. $\quad$ El hombre que asesinó a otro (I: r3. La justicia y la injuria).

5. El olor de la rosa (I: I3. La justicia y la injuria).

6. La bofetada al campesino, al caballero y al rey (I: I4. La proporción de la justicia).

7. El amor y el temor al señor (I: I4-5. La proporción de la justicia). 
8. La finalidad del matrimonio (I: I5. La proporción de la justicia).

9. El escudero que trinchaba el capón (I: I5. La proporción de la justicia).

IO. La satisfacción del hombre rico (I: I5-6. La justicia y la injuria).

II. El buen prelado (I: I7. La prudencia).

I2. El buen príncipe (I: I8. La prudencia).

I3. El buen mercader (I: I8. La prudencia).

I4. El dinero o el florín (I: 20. La fortaleza y la debilidad).

I5. El rey sabio (I: 26-7. La esperanza).

I6. Lo que darías por los dineros (I: 29. La caridad).

I7. El sabio que ve (I: 3o. La sabiduría).

I8. El sabio que siente (I: 3o. La sabiduría).

19. El sabio que huele (1: 30 . La sabiduría).

20. El sabio que come (I: 3o. La sabiduría).

2I. El sabio que duerme (I: 30 . La sabiduría).

22. El sabio que habla (I: 3I. La sabiduría).

23. El sabio que imagina (г: 3r. La sabiduría).

24. El placer del sabio (I: 31. La sabiduría).

25. El sabio que demuestra (г: 3r. La sabiduría).

26. El sabio que piensa (I: 3I. La sabiduría).

27. El sabio que piensa en la bondad divina (I: 3I. La sabiduría).

28. El sabio que va a la iglesia (I: 32 . La sabiduría).

29. El sabio que reza (I: 32. La sabiduría).

3o. El avaro (2: 33. La avaricia).

3I. El miedo del avaro (2: 34. La avaricia).

32. La imaginación del avaro (2: 34 . La avaricia).

33. El avaro que va a la iglesia (2: 34 . La avaricia).

34. El avaro que ve (2: 34. La avaricia).

35. El avaro y sus cien libras (2: 34. La avaricia).

36. El gramático avaro (2: 34. La avaricia).

37. El médico avaro (2: 34 . La avaricia).

38. El rico avaro (2: 35. La avaricia).

39. El mentiroso avaro (2: 35. La avaricia).

40. El lamento del avaro (2: 35. La avaricia).

4I. El avaro que gana (2: 35. La avaricia).

42. El hombre comilón (2: 35. La glotonería).

43. El comilón airado (2: 36 . La glotonería).

44. El comilón insatisfecho (2: 36. La glotonería).

45. El comilón pobre o ladrón (2: 37. La glotonería).

46. El comilón desvergonzado (2: 37. La glotonería).

47. El comilón no convida (2: 37. La glotonería).

48. El comilón que lo sobrelleva (2: 37. La glotonería).

49. Los sentidos son mensajeros de la lujuria (2: 37. La lujuria).

50. El que ve a una mujer bella (2: 38. La lujuria).

$5^{\text {I. }} \quad$ El que ve a una mujer bella (2: $3^{8}$. La lujuria).

52. El hombre a punto de pecar (2: $3^{8}$. La lujuria).

53. La mujer lujuriosa (2: 38. La lujuria).

54. Los hombres lujuriosos (2: 39. La lujuria). 
55. El hierro hirviendo en la mano (2: 39. La lujuria).

56. Los tres orgullos (2: 40. El orgullo).

57. El hombre orgulloso (2: 40. El orgullo).

58. El hombre orgulloso contra sí (2: 40. El orgullo).

59. El hombre de ciencia orgulloso (2: 40. El orgullo).

6o. El hombre que amaba lo que no le pertenecía (2: 40. El orgullo).

6I. El hombre orgulloso (2: 4I. El orgullo).

62. El hombre orgulloso (2: 4I. El orgullo).

63. El hombre orgulloso (2: 4I. El orgullo).

64. Los hombres enviciados (2: 4I. El orgullo).

65. Las tentaciones de los humildes (2: 4I. El orgullo).

66. El hombre perezoso (2: 42. La pereza).

67. Los efectos de la pereza (2: 42. La pereza).

68. El hombre perezoso (2: 43. La pereza).

69. El perezoso que aconseja (2: 43. La pereza).

70. El perezoso que no hace el bien (2: 43. La pereza).

7I. El perezoso que reprende (2: 43. La pereza).

72. El perezoso que imagina (2: 43. La pereza).

73. El hombre envidioso (2: 44. La envidia).

74. El envidioso que miente (2: 44. La envidia).

75. El que envidia a una mujer bella (2: 45. La envidia).

76. El envidioso que mal habla (2: 45. La envidia).

77. El envidioso que no restituye (2: 45. La envidia).

78. El envidioso que va de romería (2: 45. La envidia).

79. El envidioso mal consejero (2: 45. La envidia).

8o. El envidioso que no alaba nunca (2: 45. La envidia).

8I. El envidioso que mal habla (2: 45. La envidia).

82. El envidioso mal consejero (2: 45. La envidia).

83. El envidioso que no ama a Dios (2: 45. La envidia).

84. El loco que hace locuras (2: 46 . La ira).

85. El airado sin miedo (2: 46 . La ira).

86. El hombre airado (2: 46. La ira).

87. El hombre airado (2: 46. La ira).

88. El hombre airado mal consejero (2: 46. La ira).

89. Los mensajes de la ira (2: 47. La ira).

90. El hombre airado (2: 47. La ira).

9I. El hombre vestido de mentira (2: 48. La mentira).

92. Los oficios de la verdad (2: 48. La mentira).

93. El hombre mentiroso (2: 48. La mentira).

94. El hombre mentiroso (2: 48. La mentira).

95. El hombre mentiroso (2: 48. La mentira).

96. El que cree al mentiroso (2: 48. La mentira).

97. El hombre que jura por Dios (2: 49. La mentira).

98. El que se excusa mintiendo (2: 49. La mentira).

99. El castigo del mentiroso (2: 49. La mentira).

Ioo. El clérigo que quería una jurisdicción (2: 49. La mentira).

IOI. Las dos mentiras (2: 49. La mentira). 
IO2. La buena mujer bella (3: $5^{2}$. La justicia y la prudencia).

IO3. La satisfacción del rico (3: 52. La justicia y la prudencia).

IO4. El hombre pobre (3: 52. La justicia y la prudencia).

IO5. El amigo que asesinó a un hombre (3: 52. La justicia y la prudencia).

Io6. El hombre injurioso (3: 53. La justicia y la prudencia).

IO7. La bofetada al campesino y al rey (3: 53. La justicia y la prudencia).

Io8. El escudero que amaba su salario (3: 53. La justicia y la prudencia).

Io9. El escudero que trincha un capón (3: 53. La justicia y la prudencia).

IIO. El que desama al hombre justo (3: 54 . La justicia y la prudencia).

III. La mujer que se vende por cien sueldos (3: 54. La justicia y la prudencia).

II2. La bella mujer buena (3: 54. La justicia y la fortaleza).

II3. El hombre que asesinó a otro (3: 55. La justicia y la fortaleza).

II4. El olor de la rosa (3: 55. La justicia y la fortaleza).

II5. La bofetada al campesino y al rey (3: 55. La justicia y la fortaleza).

II6. El buen escudero injuriado (3: 55. La justicia y la fortaleza).

II7. La proporción en la mesa (3: 56 . La justicia y la temperancia).

II8. La temperancia en la mesa (3: 56 . La justicia y la temperancia).

II9. El sabor de la comida y de la bebida (3: 57. La justicia y la temperancia).

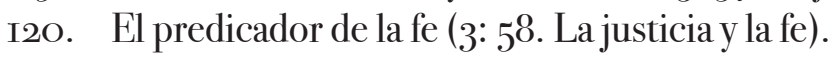

I2I. El prelado que honra la fe (3: 6o. La justicia y la fe).

I22. La tentación de la injuria (3: 6o. La justicia y la fe).

I23. El bello zapato del zapatero (3: 6o. La justicia y la fe).

I24. La habitación sin luz (3: 6r. La justicia y la fe).

I25. La mujer bella (3: 6r. La justicia y la fe).

I26. El hombre en pecado mortal (3: 6r. La justicia y la fe).

I27. El sabio que oraba (3: 65. La justicia y la sabiduría).

I28. El sabio que hacia contrición (3: 65. La justicia y la sabiduría).

I29. La mesa bien puesta (3: 8I. La fortaleza y la temperancia).

I30. El comer y el beber con moderación (3: 8I. La fortaleza y la temperancia).

I3I. La fuerza para matar una gallina (3: 87. La fortaleza y la caridad).

I32. El sabio virtuoso (3: 88. La fortaleza y la caridad).

I33. El sabio que comprende (3: 88. La fortaleza y la caridad).

134. El que ve a una mujer bella (3: 94. La temperancia y la caridad).

I35. Los averroístas (3: IO3. La fe y la sabiduría).

I36. El avaro pobre (4: II3. La avaricia y la glotonería).

I37. El avaro goloso (4: II3. La avaricia y la glotonería).

I38. El avaro triste (4: II4. La avaricia y la glotonería).

I39. El avaro que parece generoso (4: II 4. La avaricia y la glotonería).

I4O. El avaro y el lujurioso (4: II4. La avaricia y la glotonería).

I4I. El avaro y el lujurioso (4: II5. La avaricia y la glotonería).

I42. El avaro y el lujurioso (4: II5. La avaricia y la glotonería).

I43. El hombre de ciencia orgulloso (4: II6. La avaricia y el orgullo).

I44. Los hombres enviciados (4: II6. La avaricia y el orgullo).

I45. El padre del mulo (4: II7. La avaricia y el orgullo).

I46. Los palacios de Avaricia y de Orgullo (4: II9. La avaricia y la acidia).

I47. El caballo bello (4: I20. La avaricia y la envidia).

I48. El avaro envidioso (4: I2I. La avaricia y la envidia). 
I49. El avaro envidioso (4: I2I. La avaricia y la envidia).

I5O. El avaro envidioso (4: I2I. La avaricia y la envidia).

I5I. El avaro mentiroso (4: I25. La avaricia y la mentira).

I52. El avaro mentiroso (4: I25. La avaricia y la mentira).

I53. El hombre pobre (4: I25. La avaricia y la mentira).

I54. El avaro mentiroso (4: 126. La avaricia y la mentira).

I55. El avaro mentiroso (4: I26. La avaricia y la mentira).

I56. El comilón lujurioso (4: I27. La glotonería y la lujuria).

I57. El sujeto y el predicado (4: I28. La glotonería y la lujuria).

I58. El que se deleita en ganar (4: I34. La glotonería y la envidia).

I59. El que se deleita en cazar (4: 134. La glotonería y la envidia).

I60. El que se deleita en dar (4: I34. La glotonería y la envidia).

I6I. El que se deleita en jugar (4: I34. La glotonería y la envidia).

I62. El que se deleita en honrar (4: I34. La glotonería y la envidia).

I63. El que se deleita en invitar (4: I34. La glotonería y la envidia).

I64. El capón gordo (4: I38. La glotonería y la mentira).

I65. La compra del capón gordo (4: I38. La glotonería y la mentira).

I66. El comilón mentiroso (4: I38. La glotonería y la mentira).

I67. El comilón mentiroso que tocaba la comida (4: I38. La glotonería y la mentira).

I68. Los lujuriosos y los envidiosos (4: I 45. La lujuria y la envidia).

I69. El escudero que miraba a la mujer del señor (4: 154. El orgullo y la ira).

I7O. El orgulloso airado (4: I54. El orgullo y la ira).

I7I. El orgulloso airado (4: I54. El orgullo y la ira).

I72. El orgulloso airado (4: I54. El orgullo y la ira).

I73. El orgulloso airado (4: I54. El orgullo y la ira).

I74. El orgulloso airado (4: I54. El orgullo y la ira).

I75. El orgulloso airado (4: I55. El orgullo y la ira).

I76. El veguer orgulloso y airado (4: I55. El orgullo y la ira).

I77. El rey o prelado orgulloso y airado (4: I55. El orgullo y la ira).

I78. La vista del mentiroso (4: I56. El orgullo y la mentira).

I79. Los que mienten en sus oficios (4: I57. El orgullo y la mentira).

I80. El acidioso envidioso (4: I58. La envidia y la acidia).

I8I. El jorobado (4: I64. La envidia y la ira).

I82. El jugador (4: I64. La envidia y la acidia).

I83. El que da consejos (4: i64. La envidia y la ira).

I84. El hombre paciente y leal (4: I65. La envidia y la ira).

I85. El buen servidor del rey (4: I65. La envidia y la ira).

I86. El que cree en los artículos de la fe (4: I65. La envidia y la ira).

187. La envidia de Lucifer (4: I67. La envidia y la ira).

I88. El cristal que recibe el color rojo (5: I74. La justicia y la glotonería).

I89. El cuchillo y el trozo de madera (5: I75. La justicia y la glotonería).

190. Los hombres que vieron dos serpientes (5: I88. La prudencia y la avaricia).

I9I. El hombre que quería vender dos manzanas (5: I88. La prudencia y la avaricia).

192. Los dos romeros que tenían sed (5: I89. La prudencia y la avaricia).

I93. El prudente diligente (5: I96. La prudencia y la acidia).

I94. El prudente enfermo (5: I96. La prudencia y la acidia).

195. El prudente rico (5: I96. La prudencia y la acidia). 
I96. Los puercos pequeños de Berebería (5: I96. La prudencia y la acidia).

I97. El zapatero sabio (5: 197. La prudencia y la acidia).

I98. El rico negligente (5: 197. La prudencia y la acidia).

199. El hombre envidioso (5: 227. La temperancia y la envidia).

200. Los gobernantes acidiosos (5:242. La fe y la acidia).

2OI. Los averroístas (5: 263. La esperanza y la mentira).

\section{I9 La ciudad del mundo}

(IV.108 - Liber de civitate mundi [5/I3I4-Messina]. Total ejemplos: 9. Badia 2008 [TORL, 2]).

\section{Título (libro, pág. Tema).}

I. El palacio de piedras preciosas, oro y plata (prólogo: I85. Las dignidades).

2. $\quad$ El falso avaro (I: I9I. La caridad).

3. Los caballeros enemigos (I: I93-I95. La soberbia).

4. El prelado acidioso y avaro (I: I97-I99. La maldad y la perversión).

5. El glotón que robó un capón (I: 2OI. La temperancia).

6. El lujurioso que se combatía a él mismo (I: 203-205. La fortaleza).

7. $\quad$ El imprudente que esquivaba el bien (I: 207-209. La prudencia).

8. La falsa sentencia (I: 2II-2I3. La justicia).

9. $\quad$ El aceite que flota en el agua (III: 275. La impiedad). 


\section{Ediciones y estudios consultados}

Alba, Amparo; Sainz de la Maza, Carlos, 20I2, "Señas de identidad judías y cristianas en la cuentística medieval: algunos ejemplos hispánicos”, Sefarad: Revista de Estudios Hebraicos, Sefardíes y de Próximo Oriente 72-I, I45-190.

Alonso, Begoña, 2OI2, "Intersecciones del sentido figurado en el contexto de la predicación medieval: entre el tópico y el exemplum (de nuevo acerca del unicornio)", en Literatures ibèriques medievals comparades / Literaturas ibéricas medievales comparadas, Rafel Alemany, Francisco Chico ed., Alacant, Universitat d'Alacant, 53-64.

Alvar, Carlos, 20Io, Traducciones y traductores, Alcalá de Henares, Centro de Estudios Cervantinos.

Amengual, Guillem Alexandre, ed., 20Io, Ramon Llull Llibre de l'és de Déu: Llibre de coneixença de Déu: Llibre de Déu, Palma de Mallorca, Patronat Ramon Llull (NEORL, 9).

Arbona, Miguel, 1976, “Los eximplis en el Llibre de Evast e Blanquerna”, Studia Lulliana 20, 53-67.

Aragüés Aldaz, José, 1996, "Exempla inquirere et invenire: fundamentos retóricos para un análisis de las formas breves lulianas", en La literatura en la época de Sancho IV, Carlos Alvar, José Manuel Lucía Megías ed., Alcalá de Henares, Universidad de Alcalá, I996, 289-3II.

Aragüés Aldaz, José, 200o, "Falses semblances. Ejemplarismo divino y literatura ejemplar a la luz de Ramón Llull”, en Actas del VIII Congreso de la AHLM, vol. I, M. Freixas, S. Iriso, L. Fernández ed., Santander, Gobierno de Cantabria-Año Jubilar Lebaniego-AHLM, I75-I84.

Aragüés Aldaz, José, 2OI4, "Ramon Llull: la invención del milagro mariano", en Estudios de Filología e Historia en honor del profesor Vitalino Valcárcel, I. Ruiz Arzalluz et alï ed., Vitoria/Gasteiz, Universidad del País Vasco, 9I-Io9.

Aragüés Aldaz, José, en prensa, "Llull and medieval exemplary literature”, en A companion to Ramon Llull, M. D. Johnston, A. M. Austin ed., Leiden, Brill.

Artigas, Miguel Marco, 2007-2008, “La pastoreta, Fèlix, el llop i Bernat Metge: a propòsit de l’episodi inicial del Llibre de meravelles", Revista de Lenguas y Literaturas Catalana, Gallega y Vasca I3, 2I9226.

Badia, Lola, I98ia, “A propòsit dels models literaris lul-lians de la dona: Natana i Aloma”, Estudi General $2,23-28$.

Badia, Lola, I98Ib, "No cal que tragats exempli dels romans", en Estudis de llengua i literatura catalanes III (Miscel-lània Pere Bohigas I), Barcelona, Publicacions de l’Abadia de Montserrat, 87-94.

Badia, Lola, I989, "Manipulacions literàries lul-lianes: de la pastorel-la al sermó”, Estudi General 9, I327.

Badia, Lola, 1990, La narrativa segons Llull: relats instructüs de difusió universal, Palma de Mallorca, Centre d'Estudis Teològics de Mallorca.

Badia, Lola, 1992, Teoria i pràctica de la literatura en Ramon Llull, Barcelona, Quaderns Crema.

Badia, Lola, I996, "La ficción luliana en los orígenes de las letras catalanas", en Constantes y fragmentos del pensamiento luliano, Fernando Domínguez, Jaime de Salas ed., Tübingen, Max Niemeyer, 59-76. http://dx.doi.org/IO.I5I5/iber.I979.I979.9.I

Badia, Lola, I997, "Scienza e letteratura nella produzione volgare di Raimondo Lullo", en Francescanesimo in volgare (secoli XIII-XIV), Spoleto, Centro Italiano di Studi sull'Alto Medioevo, 
$245^{-269}$.

Badia, Lola, I999, "La literatura alternativa de Ramon Llull: tres mostres”, en Actes del VII Congrés de l'Associació Hispànica de Literatura Medieval Castelló de la Plana, 22-26 de setembre del 1997, vol. I, Santiago Fortuño, Tomàs Martínez Romero ed., Castelló de la Plana, Universitat Jaume I, II-32.

Badia, Lola, ed., 2002, Ramon Llull Començaments de medicina; Tractat d'astronomia, Palma de Mallorca, Patronat Ramon Llull (NEORL, 5).

Badia, Lola, 2007, "Generació o luxúria: què diu Ramon llull sobre el sexe?”, en Actes del tretzè Col·loqui Internacional de Llengua i Literatura Catalanes, Girona 2003, vol. 3, Barcelona, Publicacions de l’Abadia de Montserrat, I25-I44.

Badia, Lola, ed., 2008, Ramon Llull Llibre de la disputa del clergue Pere i de Ramon; Llibre de la ciutat delmón, Turnhout-Santa Coloma de Queralt, Brepols-Obrador Edèndum (TORL, 2).

Badia, Lola, 2009, "Il re che si meravigliò del volare del falco: un appunto su Raimondo Lullo e il letterario", en Multas per gentes, Marco Prandoni, Gabriele Zanello ed., Padova, Il Poligrafo, 423-430.

Badia, Lola, 2012, "Consideraciones sobre la edición crítica el Félix o Libro de maravillas", en El texto medieval: de la edición a la interpretación, Pilar Lorenzo, Simone Marcenaro ed., Santiago de Compostela, Universidad de Santiago de Compostela, 355-370.

Badia, Lola; Bonillo, Xavier; Gisbert, Eugènia; Fernàndez Clot, Anna; Lluch, Montserrat, ed., 2OI2, Ramon Llull Llibre de meravelles, vol. I., Palma de Mallorca, Patronat Ramon Llull (NEORL, IO).

Badia, Lola; Bonillo, Xavier; Gisbert, Eugènia; Fernàndez Clot, Anna; Lluch, Montserrat, ed., 20I5, Llibre de meravelles, vol. 2, Palma de Mallorca, Patronat Ramon Llull (NEORL, I3).

Batalla, Josep; Cabré, Lluís; Ortín, Marcel, ed., 20o6, Ramon Llull Retòrica nova, Turnhout-Santa Coloma de Queralt, Brepols-Obrador Edèndum (TORL, I).

Batllori, Miguel, I993, Ramon Llull i el lul·lisme, València, Tres i Quatre.

Batllori, Miguel, ed., I948, Ramón Llull Obras literarias, Madrid, Editorial Católica.

Batllori, Miguel, ed., I98I, Ramón Llull Obra escogida, Madrid, Alfaguara.

Bauçà, Manuel, I989, L'exemplarisme de Ramon Llull, Palma de Mallorca, Centre d'Estudis Teològics de Mallorca.

Beer, Jeanette, I98I, Narrative Conventions of Truth in the Middle Ages, Genève, Droz.

Berlioz, Jacques; Bremond, Claude; Velay-Vallantin, Catherine, ed., I989, Formes médiévales du conte mereveilleux, Paris, Stock.

Berlioz, Jacques; Polo, Marie Anne, ed., I998, Les exempla médiévaux: nouvelles perspectives, Paris, Champion.

Berlioz, Jacques; Polo, Marie Anne, ed., I999, L'animal exemplaire au Moyen Âge (VÉ-XVÉ siècle), Rennes, Presses Universitaires de Rennes.

Bétérous, Paule, I978, "Ramon Llull et le renouvellemente du thème des miracles Mariaux au XIIIle siècle", Cultura Neolatina 38, 37-47.

Bizzarri, Hugo, 2009, "Le passage du proverbe à l' exemplum et de l'exemplum au proverbe", en Tradition des proverbes et des exempla dans l'Occident médiéval / Die Tradition der Sprichwörter und exempla im Mittelalter, Hugo Bizarri, Martin Rohde ed., Berlin-New York, Walter de Gruyter, 7-23.

Bizzarri, Hugo, 20IO, "De la chria al exemplum", en Actas del XIII Congreso Internacional Asociación 
Hispánica de Literatura Medieval, Valladolid 20og, vol. I, José Manuel Fradejas, Deborah Anne Dietrick, María Jesús Díez Garretas, Demetrio Martín Sanz ed., Valladolid, Universidad de Valladolid, $43^{\mathrm{I}-445}$.

Blasco, Almudena, 20IO, "Modelos de mujer en los sermones dirigidos a la sociedad barcelonesa del siglo XIII”, Revista de Poética Medieval 24, 77-92.

Boehne, Patricia J., 1975, Dream and fantasy in 14 th and 15th century catalan prose, Barcelona, Hispam.

Bohigas, Pere, I962, El Libro español: ensayo histórico, Barcelona, Gili.

Bohigas, Pere, ed., I956, Miracles de la verge Maria: col-lecció del segle XIV, Barcelona, Muntaner.

Bonillo, Xavier, 2003, El paradís i l'infern segons el "Llibre de meravelles" de Ramon Llull, Barcelona, Universitat de Barcelona.

Bonillo, Xavier, 2004, "Els exemples del paradís i de l'infern del Llibre de meravelles de Ramon Llull", Studia Lulliana 44, 53-78.

Bonillo, Xavier, 2005, "L'estructura dels llibres del Paradís i de l’Infern al Fèlix de Ramon Llull”, en Actes de les Jornades Internacionals Lul.lianes. Ramon Llull als. XXI. Palma, 1, 2 is d'abril de 2004, Maria Isabel Ripoll ed., Palma de Mallorca-Barcelona, Universitat de les Illes Balears-Universitat de Barcelona, 2I7-233.

Bonillo, Xavier, 2007, Edició crítica i estudi dels llibres I, II, IX i X del "Llibre de meravelles" de Ramon Llull, Barcelona, Universitat de Barcelona.

Bonillo, Xavier, 2008, Literatura al "Llibre de meravelles" de Ramon Llull, Barcelona, Universitat Oberta de Catalunya.

Bonillo, Xavier, 2OI5, "Presentació i antecedents", Exempla Lulliana, 2I-I2-2OI4, http://tinyurl.com/ ptlcco3 (checked: 3-O3-2OI5).

Bonillo, Xavier, 20I6, "Reelaboracions i reinterpretacions de la tradició en l'obra de Ramon Llull a partir de dos exemples del Llibre de meravelles", Studia Lulliana [en curso de publicación].

BDRL (Base de dades Ramon Llull), http://www.orbita.bib.ub.es/llull (checked: 3I-O3-20I5).

Bonner, Anthony, ed., I993, Ramon Llull. Llibre del gentil e dels tres savis, Palma de Mallorca, Patronat Ramon Llull (NEORL, 2).

Bonner, Anthony, ed., 1998, Obres selectes de Ramon Llull, Palma de Mallorca, Editorial Moll, 2 vol.

Brancaleone, Davide, 2002, "Il Libro dele bestie di Raimondo Lullo nella versione trecentesca veneta", Per Leggere: I Generi della Lettura 2, I7-62.

Bremond, Charles; Le Goff, Jacques; Schmitt, Jean-Claude, ed., I996, L'exemplum, Brepols, Turnhout.

Brummer, Rudolf, I979, “Sobre les fonts literàries del Blanquerna de Ramon Llull”, Iberorromania 9, I-II. http://dx.doi.org/IO.I5I5/iber.I979.I979.9.I

Brummer, Rudolf, I98I, "Hi ha un model literari per al Llibre de contemplació en Déu de Ramon Llull?, en Estudis de llengua i literatura catalanes III (Miscel-lània Pere Bohigas I), Barcelona, Publicacions de l’Abadia de Montserrat, 79-86.

Brummer, Rudolf, ı986, "La importància de la novel-la Blanquerna de Ramon Llull en les literatures europees de l'Edat Mitjana”, Randa I9, I37-I4I.

Bultot, Robert, ed., I982, Les genres littéraires dans les sources théologiques et philosophiques médiévales, Louvain, Munk Olsen.

Burgoyne, Jonathan, 2007, Reading the exemplum right: fixing the meaning of "El conde Lucanor", 
Chapel Hill, University of North Carolina Press.

Butinyà, Julia, I996, "El cor del Llibre de meravelles lul-lià”, Revista de Filología Románica I3, 89-ı06.

Cabré, Lluís; Ortín, Marcel; Pujol, Josep, I998, “Conèixer e haver moralitats bones”, Studia Lulliana 28, I39-167.

Cabré, Miriam, 2005, "La manera pus fina: los Exemplis, Faules o Istòries en los Verses Proverbials de Guillem de Cervera", en Actas del IX Congreso Internacional de la Asociación Hispánica de Literatura Medieval, A Coruña 2001, vol. I, Carmen Parrilla, Mercedes Pampín ed., Noia, Toxosoutos, 543-558.

Cacho Blecua, José Manuel, 1998, "Del exemplum a la estoria ficticia: la primera lección de Zifar", en Tipología de las formas breves románicas medievales, Juan Paredes, Paloma Gracia ed., I998, Granada, Universidad de Granada, 2I9-236.

Campbell, Killis, ed., I9O7, The seven sages of Rome, Boston-New York-Chicago-London, Ginn and Company.

Campos, Axayácatl, 2007, "El exemplum vivido en el Libro del cavallero Zifar", en Actas del XI Congreso Internacional de la Asociación Hispánica de Literatura Medieval, León 2005, vol. I, Armando López Castro, Luzdivina Cuesta ed., León, Universidad de León, 389-394.

Cárdenas, Anthony J., 20I2, "(Mis)reading the Libro de buen amor: exemplary ambiguity and ambiguous exempla", Romance Notes, 52, I, 3-II.

Carreras i Artau, Joaquim; Batllori, Miquel; Carreras i Artau, Tomàs; Rubió i Balaguer, Jordi, ed., I957I96o, Ramon Llull Obres essencials de Ramon Llull, Barcelona, Selecta, 2 vol.

Cátedra, Pedro, I993, “Los exempla de los sermones castellanos de san Vicente Ferrer”, en Ex-Libris. Homenaje al profesor José Fradejas, vol. I, José Romera, Antonio Lorente, Ana Maria Freire ed., Madrid, UNED, 59-94.

Cátedra, Pedro, 1994, Sermón, sociedad y literatura: san Vicente Ferrer en Castilla (1411-1412), Salamanca, Junta de Castilla y León.

Connochie, Chantal, 20II, "Translatio sudï: la circulation exemplaire du Livre de Sydrach", en Mobilidade e Literatura na Idade Média; formas, trajectórias e sentidos: actas do Colóquio / Mobilité et littérature au Moyen Age; formes, enjeux et significations: actes du Colloque, Carlos F. Clamote, ed., Lisboa, Universidade Aberta, 30I-3IO.

Copeland, Rita, I99I, Rhetoric, hermeneutics, and translation in the middle ages: academic traditions and vernacular texts, Cambridge, Cambridge University Press. http://dx.doi.org/IO.IOI7/ $\underline{\mathrm{CBO}} 9780511597534$

Corti, Maria, I978, "Structures idéologiques et structures sémiotiques au XIIIe siècle”, Travaux de Linguistique et Littérature I6-I, 93-IO5.

Crane, Thomas Frederick, I89o, The exempla or illustrative stories from the sermones vulgares of Jacques de Vitry, London.

Crombach, Mechthild, ed., I97I, Bocados de oro, Bonn, Romanisches Seminar der Universität Bonn.

Dahan, Gilbert, I980, "Notes et textes sur la poétique au Moyen Âge”, Archives d'Histoire Doctrinale et Littéraire du Moyen Âge 55, I7 I-239.

Davy, Marie-Madeleine, r988, Il simbolismo medieval, Roma, Edizioni Mediterranee.

Domínguez, Fernando, 2007, "Una lectura del Llibre de meravelles como ars praedicandi", Caplletra 43, I3I-I60. 
Domínguez, Fernando, ed., 199I, Ramon Llull Llibre de virtuts e de pecats, Palma de Mallorca, Patronat Ramon Llull (NEORL, I).

Dronke, Peter, 1985, Fabula explorations into the uses of myth in medieval platonism, Leinden, Brill.

Dubost, Francis, I99I, Aspects fantastiques de la littérature narrative médievale (XIIème-XIIIè siècles), Paris, Honoré Champion, 2 vol.

Dubuis, Roger, 1973, Les cent nouvelles nouvelles et la tradition de la nouvelle en France au Moyen Age, Grenoble, Presses Universitaires de Grenoble.

Durán, Armando, 1973, Estructura y técnicas de la novela sentimental y caballeresca, Madrid, Gredos.

Faral, Edmond, I9I3, Recherches sur les sources latines des contes et romans courtois du Moyen Age, Paris, Champion.

Faral, Edmond, 1982, Les arts poétiques du XIIe et du XIIIe siècle, Genève-Paris, Slatkine-Champion.

Ferlampin-Acher, Christine, 2003, Merveilles et topique merveilleuse dans les romans médiévaux, Paris, Champion.

Fidora, Alexander; Rubio, Josep Enric, ed., 2003, Raimundi Lulli Opera Latina, Tomus XXVIII: Op. 49$5_{2}^{2}$ Liber de sancta Maria in Monte Pessulano anno MCCXC conscriptus, cui Liber de passagio Romae anno MCCXCII compositus necnon brevis notitia operum aliorum incerto tempore ac loco perfectorum adnectuntur, Turnhout, Brepols (ROL, 28).

Galley, Claude, 1987 , "Une autre évolution du conte oriental: Lo llibre de les bestiès de Ramon Llull”, en Atti del V Colloquio della International Beast Epic, Fable and Fabliau Society, Alessandria, Edizioni dell'Orso, 259-27I.

Galmés, Salvador, Caimari, Andreu; Guilleumas, Rosalia, ed., I935-1954, Ramon Llull Libre de Evaste Blanquerna, Barcelona, Barcino, 4 vol.

Galmés, Salvador, ed., I930, Ramon Llull Libre de demostracions, Palma de Mallorca, Tous y Bauçà (ORL, I5).

Galmés, Salvador, ed., I931-I934, Ramon Llull Libre de meravelles, Barcelona, Barcino, 4 vol.

Galmés, Salvador, ed., I935, Ramon Llull Libre d'intenció; Arbre de filosofia d'amor; Oracions e contemplacions del enteniment; Flors d'amors eflors d'entelligència; Oracions de Ramon, Palma de Mallorca, Tous y Bauçà (ORL, I8).

Garnier, François, 1989, Le langage de l'image au Moyen Áge, Paris, Le Léopard d’Or.

Gayà, Jordi, 1979, "Els exemples lul-lians: noves referències a la influència àrab”, Studia Lulliana 23, 2O6-2II.

Gayà, Jordi, I980, "Sobre algunes estructures literàries del Libre de Meravelles", Randa Io, 63-69.

Giannetti, Andrea, ed., I996, Libre dels set savis de Roma, Bari, Adriatica Editrice.

Gisbert, Eugènia, 2004, "Metaforice loquendo: de l'analogia a la metàfora en els Començaments de medicina de Ramon Llull”, Studia Luliana 44, I7-52.

González Casanovas, Roberto J., I998, La novela ejemplar de Ramon Llull: interpretaciones literarias de la misión, Madrid, Júcar.

González Palencia, Miguel, ed., I948, Pedro Alfonso Disciplina clericalis, Madrid-Granada, CSIC.

Graf, Arturo, I984, Miti, leggende e superstizioni del Medio Evo, Milano, Arnaldo Mondadori.

Grimalt, Josep A., 2002, “Notes sobre les fonts del Llibre de les bèsties de Ramon Llull”, Randa 48, 37- 
46.

Gutiérrez Martínez, María del Mar, ed., 2OII, "Edición del Libro de los ejemplos por A.B.C. (2 ${ }^{\mathrm{a}}$ parte)", Memorabilia I3, I-2I6.

Haro, Marta, ed., 2007, Exemplario contra los engaños y peligros del mundo, València, Universitat de València.

Hauf, Albert G., 2002, "Sobre l'Arbor exemplificalis", en Arbor Scientiae: Der Baum des Wissens von Ramon Llull, Francisco Domínguez Reboiras et alï ed., Brepols, Turnhout, 3O3-342.

Haywood, Louise M., 20II, "Choosing and testing spouses in medieval exemplary literature", en $A$ companion to Spanish women's studies, Xon de Ros, Geraldine Hazbun ed., Woodbridge, Tamesis, 69-8o.

Heusch, Carlos, 2009, "L'enxiemplo dans El conde Lucanor de Juan Manuel: de l'exemplum au proverbe, entre clarté et obscurité", en Tradition des proverbes et des "exempla" dans l'Occident médiéval / Die Tradition der Sprichwörter und "Exempla" im Mittelalter, Hugo Bizarri, Martin Rohde ed., Berlin-New York, Walter de Gruyter, 253-274.

Higashi, Alejandro, 2007, ¿Cuento, fábula o exemplum? ¿Quién pone nombre a las formas breves de la literatura medieval?”, en De los orígenes de la narrativa corta en Occidente, Reinhard Huamán ed., Lima, Ginebra Magnolia, 33-39.

Hillgarth, Jocelyn N., I99I, Readers and books in Majorca, 1229-155o, Paris, Centre National de la Recherche Scientifique, 2 vol.

Huchet, Jean-Charles, 1984, Le roman occitan médiéval, Paris, Presses Universitaires de France.

Jauss, Hans Robert, I985, "I generi minori del discorso esemplare come sistema di comunicazione letteraria”, en Il racconto, Michelangelo Picone ed., Bologna, Il Mulino, 53-72.

Jauss, Hans Robert, I989, Alterità e modernità della letteratura medievale, Torino, Bollati Boringhieri.

Johnston, Mark D., I978, The semblance of signifiance: language and exemplarism in the "Art" of Ramon Llull, Baltimore, Johns Hopkins University, tesis doctoral

Johnston, Mark D., I992, "Exemplary reading in Ramon Llull's Libre de meravelles", Forum for Modern Language Studies 28, 235-25o. http://dx.doi.org/IO.IO93/fmls/XXVIII.3.235

Johnston, Mark D., ed., I994, Ramon Llull's "New Rethoric": Text and translation of Llull's "Rethorica Nova", Anaheim, Hermagoras Press.

Keller, John E.; Linker, Robert W., ed., I979, Barlaam e Josafat, Madrid, CSIC.

Kniazzeh, Charlotte; Neugaard, Edward, ed., I977, Vides de sants rosselloneses, Barcelona, Fundación Salvador Vives Casajuana, 3 vol.

Lacarra, María Jesús, I979, Cuentística medieval en España: los orígenes, Zaragoza, Universidad de Zaragoza.

Lacarra, María Jesús, I985, “Strutture e tecniche della narrativa castigliana: l’inserimento di racconti”, en Il racconto, Michelangelo Picone ed., Bologna, Il Mulino, 205-230.

Lacarra, María Jesús, 2007, "El Exemplario contra los engaños y peligros del mundo: las transformaciones del Calila en Occidente", en Exemplario contra los engaños y peligros del mundo, Marta Haro ed., València, Universitat de València, I5-42.

Lacarra, María Jesús, ed., I999, Cuento y novela corta en España: edad media, Barcelona, Crítica.

Lacarra, María Jesús; López Estrada, Fernando, I993, Orígenes de la prosa, Madrid, Júcar. 
Lalomia, Gaetano, 2004, “La rappresentazione del conflitto nel Llibre de les bèsties di Ramon Llull”, La Parola del Testo 8/2, 355-368.

Le Goff, Jacques, 1985, “L’exemplum”, en Il racconto, Michelangelo Picone ed., Bologna, Il Mulino, 95IO9.

Le Goff, Jacques, 2003, Limmaginario medievale, Bari-Roma, Laterza.

Lecoy de la Marche, Antoine, I886, La chaire française au Moyen Age, spécialement au XIIIe siècle d'après les manuscrits contemporains, Paris ( $2^{\mathrm{a}} \mathrm{ed}$.).

Lefévre, Yves, ed., I954, L'Elucidarium et les lucidaires, Paris, De Bocard Éditeur.

Lippini, Pietro, I988, Storie e leggende medievali: le "Vitae fratrum" di Geraldo di Frachet o. p., Bologna, Edizioni Studio Domenicano.

Little, Andrew G., ed., I966, Liber exemplorum ad usum praedicantium, Farnborough, Gregg.

Llinarès, Armand, 197I, “Theorie et practique de l’allegorie dans le Libre de contemplació", Studia

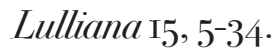

Llinarès, Armand, 1973, "Remarques sur les formes du symbolisme lullien", Traza y Baza 3, 27-44.

Llinarès, Armand, 1987, "Les singes, le ver luisant et l'oiseau: note sur l'utilisation répétée d'une même fable dans l'oeuvre de Lulle", Romania Io8/ı, 97-Io6.

Llinarès, Armand, ed., I964, Raymond Lulle Le livre des bêtes: version française du XVe siècle, Paris, Klincksieck.

Longère, Jean, ed., I997, Historia occidentalis: tableau de l’occident au XIIIè siècle, Paris, Éditions du Cerf.

Looze, Laurence de, 20io, “Analogy, exemplum, and the first tale of Juan Manuel’s El conde Lucanor”, Hispanic Review 78-3, 30I-322.

Luzón, Rubén, 2006, “Una aproximación a la noción de exemplum en la obra luliana, seguida de un breve comentario en los exempla del capítulo 62 del Llibre de meravelles", Revista de Lenguas y Literaturas Catalana, Gallega y Vasca 12, 253-276. http://dx.doi.org/IO.5944/rllcgv.vol.I2.2006.5920

Marsan, R. E., I974, Itinéraire espagnol du conte médiéval (VIII -XVtésiècles), Paris, Librairie C. Klincksieck.

Martín, Llúcia, I996, La tradició animalística en la literatura catalana medieval, València, Alacant, Universitat d'Alacant.

Martín, Llúcia, 1997, "Algunes consideracions sobre la relació entre les faules del Llibre de les bèsties de Ramon Llull i l'original oriental”, Catalan Review II, 83-II2.

Martín, Llucia, 2003, “'On pus escura és la semblança, pus altament entén l’enteniment qui aquella semblança entén’: Ramon Llull i el didactisme cientificoteològic del Llibre de meravelles”, Randa 50, 25-39.

Martínez Romero, Tomás, 2002, Aproximació als sermons de sant Vicent Ferrer, Paiporta, Denes.

Maulu, Marco, 2013, "Ramon Llull e la scrittura allegorica nel Libre de les bèsties". Rhesis 4-2, 25I-276.

Medina, Jaume, ed., 2005, Raimundi Lulli Opera Latina, Tomus XXX: Op. 97-100 in Cypro, Alleas in Cilicia deque transmarinis veniente annis MCCCI-MCCCII compilata, Turnhout, Brepols (ROL, 30).

Minervini, Vincenzo, ed., 1982, Il libro di Sidrac: versione catalana, Bari, Lerici.

Montoya, Jesús, I981, Las colecciones de milagros de la Virgen en la edad media: el milagro literario, 
Granada, Universidad de Granada.

Morse, Ruth, I99I, Truth and convention in the middle ages: rhetoric, representation and reality, Cambridge, Cambridge University Press.

Murphy, James J., 1974, Rhetoric in the middle ages: a history of rhetorical theory from saint Augustine to the renaissance, Berkeley-Los Angeles, University of California Press.

Neugaard, Edward J., I971, "The Sources of the Folk Tales in Ramon Llull's Llibre de les bèsties”, Journal of American Folklore, 84, 333-337.

Neugaard, Edward, I99I, "The short narrative in medieval catalan literature”, Catalan Review 5-2, 8996.

Neugaard, Edward, I993, Motif-index study of catalan folktales, Binghamton NY, Medieval \& Renaissance Texts \& Studies.

Orazi, Veronica, 200o, “Die verfolgte Frau: per l'analisi simiologica di un motivo folclorico e delle sue derivazioni medievali (con speciale attenzione all'ambito catalano)”, Estudis Romànics 22, IOI-I38.

Orazi, Veronica, ed., I999, "Història de la filla del rei d'Hungria" e altri racconti catalani tardomedievali: studio folclorico ed edizione critica, Viareggio, Mauro Baroni.

Pabst, Walter, 1972, La novela corta en la teoría y en la creación literaria: notas para la historia de su antinomia en las literaturas románicas, Madrid, Gredos.

Palafox, Eloisa, 1998, Las éticas del exemplum: "Los castigos del rey don Sancho IV", "El conde Lucanor" y el "Libro de buen amor", México, Universidad Nacional Autónoma de México.

Pépin, Jean, 1987, La tradition de l'allégorie de Philon d'Alexandrie à Dante, Paris, Études Augustiniennes.

Platelle, Henri, ed., 1997, Thomas de Cantimpré Les exemples du "Livre des abeilles": une vision médiévale, Turnhout, Brepols.

Polo, Marie Anne, 20IO, “De l'exemplum monastique à l'exemplum mendiant: continuités et ruptures", en Didaktisches Erzählen: Formen literarischer Belehrung in Orient und Okzident, Regula Foster, Romy Günthart ed., Frankfurt am Main, Peter Lang, 55-83.

Pons, Antoni Joan; Gayà, Jordi; Schib, Gret, ed., I996, Ramon Llull Llibre dels articles de la fe; Llibre què deu hom creure de Déu; Llibre contra anticrist, Palma de Mallorca, Patronat Ramon Llull (NEORL, 3 ).

Pring-Mill, Robert D. F., I99I, "Els recontaments de l'Arbre exemplifical de Ramon Llull: la transmutació de la ciència en literatura", en Estudis sobre Ramon Llull (1956-1978), Barcelona, Curial EdicionsPublicacions de l'Abadia de Montserrat, 307-3I\%.

Renedo, Xavier, 2007, “Eiximenis, els exemples i l'art de riure”, en Actes del Tretzè Col-loqui Internacional de Llengua i Literatura Catalanes, Girona 2003, vol. 3, Barcelona-Girona, Publicacions de l'Abadia de Montserrat, 7-34.

Riquer, Martí de, I964, Història de la literatura catalana, Barcelona, Ariel, 3 vol.

Riquer, Martí de, I968, La leyenda del graal y temas épicos medievales, Madrid, Editorial Prensa Española.

Riquer, Martí de, 1985, "Il racconto cortese in Catalogna", en Il racconto, Michelangelo Picone ed., Bologna, Il Mulino, 275-298.

Rodríguez Velasco, Jesús D., ed., I999, Castigos para celosos: consejos para juglares, Madrid, Gredos.

Roth, Detlef, ed., 2004, Historia septem sapientum, Tübingen, Max Niemeyer Verlag. 
Rubió i Balaguer, Jordi, I985 [I959], “Alguns aspects de l'obra literària de Ramon Llull”, en Ramon Llull i el lul.lisme, Barcelona, Publicacions de l’Abadia de Montserrat (Obres de Jordi Rubió i Balaguer, III), 248-299.

Santanach i Suñol, Joan, 2005, "Dos exemples de Ramon Llull inclosos en un recull de miracles", Randa $55,7-\mathrm{I} 3$.

Santanach, Joan, ed., 2005, Ramon Llull Doctrina pueril, Patronat Ramon Llull, (NEORL, 7).

Schmitt, Jean-Claude, 1985, Prêcher d'exemples, Paris, Stock.

Soler, Albert, ed., I988, Ramon Llull Llibre d’orde de cavalleria, Barcelona, Barcino.

Taylor, Barry, 1995, "Some Complexities of the Exemplum in Ramon Llull's Llibre de les bèsties", The Modern Language Review 90-3, 646-658.

Taylor, Barry, 2007, “Orígenes de la novela: el arte narrativo del exemplum medieval”, en De los orígenes de la narrativa corta en Occidente, Reinhard Huamán ed., Lima, Ginebra Magnolia, 25I-266.

Taylor, Barry, 2009, "Don Juan Manuel, lector de la literatura sapiencial: preceptiva y modelo", Revista de Poética Medieval 23, I35-I5O.

Taylor, Barry, 20IO, "Los libros de materia predicable: ¿obras de referencia o lectura privada”, Revista de Poética Medieval 24, 2II-224. http://dx.doi.org/IO.2307/373432I

ThEMA (Thesaurum Exemplorum Medï Aevi, Groupe d'Anthropologie Historique de l'Occident Médiévale), http://www.ehess.fr/gahom/thema (checked 3-O-O3-2OI5).

Thompson, Stith, 1975, Motif-Index of folk-literature: a classification of narrative elements in folktales, ballads, myths, fables, medieval romances, exempla, fabliaux, jest-books and local legends, 6 vol., London, Bloomintong.

Torre, Ventura de la, ed., 2004, Gesta romanorum: "exempla" europeos del siglo XIV, Madrid, Akal.

Tous, Miquel; Ginard, Rafel, ed.,I95o, Ramon Llull Libre de home: Libre de ànima racional: Libre dels àngels, Palma de Mallorca, Tous y Bauçà $(O R L, 2 \mathrm{I})$.

Varanini, Giorgio; Baldassari, Guido, ed., I993, Racconti esemplari del due e trecento, Roma, Salerno Editrice.

Varvaro, Alberto, I968, Struttura e forme della letteratura romanza del medioevo, Napoli, Liguori.

Varvaro, Alberto, 1992, "Note su Ramon Llull, narratore”, en Atti del Convegno Internazionale Ramon Llull; il lullismo internazionale, l'Italia. Napoli, зо е зı marzo, 1 aprile 1989, Giuseppe Grilli ed., Napoli, Istituto Universitario Orientale, 199-207.

Viera, David J., I990, "Exempla in the Libre de Sancta Maria and traditional medieval marian miracles", Catalan Review 4, 22I-23I.

Viera, David J., I996-I997, "Modifications in the exempla and narratios of Francesc Eiximenis", Hispanófila. Literatura I40, I-8.

Viera, David J., 2002, "Francesc Eiximenis' brief compendius on medieval miracles: El Primer del Crestià, chapters 56-59", Catalan Review I4-I-2, 22I-228.

Viera, David J., 2003-2004, "Els exempla de Francesc Eiximenis", Boletín de la Real Academia de Buenas Letras de Barcelona 49, IO3-II9.

Vincensini, Jean-Jacques, 2000, Motifs et thèmes du récit médiéval, Paris, Nathan.

Violo, Emilio ed., I980, Libro de los engaños e de los asayamientos de las mugeres, Napoli, Liguori 
Editore.

Welter, Jean T., I973a, L'exemplum dans la littérature religieuse et didactique de Moyen Áge, Genève, Slatkine Reprints.

Welter, Jean T., I973b, La tabula exemplorum secundum ordinem alphabeti: recueil d'exempla compilé en France à la fin du XIII siècle, Genève, Slatkine Reprints.

Ysern, Josep Antoni, I990, "La Legenda aurea i el Recull d'eximplis", en Estudis de Llengua i Literatura Catalanes XXI (Miscel-lània Joan Bastardas 4), Barcelona, Publicacions de l’Abadia de Montserrat, $37-48$.

Ysern, Josep Antoni, I993, "Els exempla al voltant de l'amistat en el Recull d'eximplis", en Miscel.lània Joan Fuster, vol. 6, Barcelona, Publicacions de l’Abadia de Montserrat, 23-46.

Ysern, Josep Antoni, 1994, "El cos, el sexe i la dona en el Recull d'eximplis”, Caplletra 13, 35-52.

Ysern, Josep Antoni, I995, “Acostament al concepte d'exemplum des de la perspectiva d'un exemplari català del XV”, Zagadnienia Rodzajów Literackich 38, 9-31.

Ysern, Josep Antoni, I996-I997, "Retòrica sermonària, exempla i construcció textual de l’Espill de Jaume Roig", Revista de Lenguas y Literaturas Catalana, Gallega y Vasca 5, I5-180.

Ysern, Josep Antoni, I999, "Nota sobre la creativitat literària de Francesc Eiximenis en l'ús d'exempla", en Estudis de Llengua i Literatura Catalanes XXXIX (Homenatge a Arthur Terry 3), Barcelona, Publicacions de l'Abadia de Montserrat, 5-37.

Ysern, Josep Antoni, ed., I999-2000, "Edició i estudi del Recull d'exemples morals, contingut en el ms. S. Cugat 39 de l'Arxiu de la Corona d'Aragó”, Butlletí de la Reial Acadèmia de Bones Lletres de Barcelona 47, 5- I-I26. $^{-1}$

Ysern, Josep Antoni, I999a, “Exempla i estructures exemplars en el primer llibre del Fèlix”, Studia Lulliana 39, 25-54.

Ysern, Josep Antoni, 1999b, “Estudi i edició dels exempla esparsos del ms. Santes Creus 49-olim 23pertanyent a la Biblioteca Pública de Tarragona”, Zeitschrift für Katalanistik ı2, 49-82.

Ysern, Josep Antoni, 2000, "Els elements meravellosos en el Recull d'eximplis", en Actes de l'Onzè Col-loqui Internacional de Llengua i Literatura Catalanes, Palma 1997, vol. 2, Joan Mas i Vives, Joan Miralles i Monserrat, Pere Rosselló Bover ed., Barcelona, Publicacions de l'Abadia de Montserrat, 387$4 \mathrm{I} 2$.

Ysern, Josep Antoni, 2003, "Sant Vicent Ferrer: predicació i societat", Revista de Filología Románica 2O, 73-IO2.

Ysern, Josep Antoni, 2007, "Insiste cum exemplis: sobre els exempla vicentins", en El fuego y la palabra: San Vicente Ferrer en el 550 aniversario de su canonización: actas del I Simposio Internacional Vicentino, Emilio Callado ed., València, Generalitat Valenciana, III-I32.

Ysern, Josep Antoni, ed., 2004. Arnau de Lieja Recull d'exemples i miracles ordenat per alfabet, 2 vol., Barcelona, Barcino. 